\title{
Hemichordata (Enteropneusta \& Pterobranchia, incl. Graptolithina): A review of their fossil preservation as organic material
}

\author{
JöRg MALETZ
}

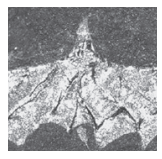

\begin{abstract}
Hemichordata and especially the Pterobranchia (Cephalodiscida and Graptolithina) can be regarded as useful examples to understand the fossil preservation of organically preservable (non-mineralized) fossils through geological history due to the commonality of their fossils in Palaeozoic sediments. The organisms consist of organic materials of three different types, the zooids (cellular tissues), the stolon system (recalcitrant matter) and the tubaria (recalcitrant matter). These materials differ considerably in their taphonomical changes and final preservational potential. While the softbodied zooidal or cellular tissues, similar to the bodies of the phylogenetically related enteropneust worms, are nearly impossible to preserve, the recalcitrant material of pterobranch tubaria is extremely common in the early Palaeozoic fossil record. The durable stolon systems of benthic graptolites are largely found in residues from the dissolution of carbonate rocks. Diagenesis, metamorphism and tectonics modify pterobranch tubaria within the sediment. Tectonic distortion and subsequent weathering may have the largest influence on the destruction or preservation of these fossils. Graptolite reflectance is used commonly in Palaeozoic sediments to determine the thermal maturity of the encasing sediments. These maturity investigations and comparisons show that organic materials of animals and plants behave similarly when subjected to geological modifications and, thus, can used to interpret taphonomical changes of fossil preservation in a consistent way. The review includes also an overview on fossil lagerstätten with important graptolite components in their faunal associations and the preservational interpretations derived from these. In this respect, it is important to determine preservational aspects carefully and to use precise terminology to describe the fossil material, to recognize fossil modifications and replacements, both in originally organically preserved fossils and in mineralic remains like shells or skeletons. - Key words: Hemichordata, graptolites, taphonomy, preservation, organic material, lagerstätten.
\end{abstract}

Maletz, J. 2020. Hemichordata (Enteropneusta \& Pterobranchia, incl. Graptolithina): A review of their fossil preservation as organic material. Bulletin of Geosciences 95(1), 41-80 (13 figures). Czech Geological Survey, Prague. ISSN 1214-1119. Manuscript received November 11, 2019; accepted in revised form February 10, 2019; published online March 27, 2020; issued March 31, 2020.

Jörg Maletz, Department of Geology, Fu Berlin, Malteserstrasse 74-100, D-12249 Berlin, Germany; Yorge@zedat. fu-berlin.de

Fossil preservation has been discussed at length in numerous publications, but still many details are unclear or have not been considered. It is usually discussed in relation to individual fossil groups (e.g. bacteria, brachiopods, graptolites, plants, trilobites, vertebrates) or types of fossil lagerstätten ( $c f$. Seilacher 1970). In the Hemichordata, the preservation of the fossils is especially important, as the involved materials differ considerably between the two groups, the Enteropneusta (Fig. 1A) and the Pterobranchia (Fig. 1B-D).

The results found in the fossil preservation are often interpreted from the visual aspects of the fossils only, and without consideration of the composition and reaction of the various materials involved in the decay processes and the subsequent fossilization processes over millions of years. Also a differentiation of originally preserved organic material and replacement of this due to later processes is often not considered. Briggs (2003) suggested replication of the morphology by rapid in situ growth of minerals as essential to preserve labile tissues, which means the loss of the original organic material through geological processes and replacement by secondarily formed minerals.

Decay-retardation during early biostratinomic processes may increase the potential for the preservation of fossils, not just in organically preserved material, but also in mineralic skeletons or shells. Important changes, however, modify the fossils considerably during later geological processes. To gain insight into the preservation of fossils it is necessary to consider the changes through these geological processes and to understand the various paths necessary to produce the final results, to see what happens to materials during numerous geological processes in Earth history. The fossilization of the Hemichordata may serve as a very important and useful example here. 
In recent years, theoretical considerations and mineralogical interpretations (e.g. Page et al. 2008, Wilson et al. 2016, Kloss et al. 2017, Parry et al. 2017) have been considered more important than experimental methods like decay experiments with extant taxa (e.g. Darroch et al. 2012; Schiffbauer et al. 2012; Murdock et al. 2014, 2016; Butler et al. 2015; Nanglu et al. 2015; Sansom 2016; Beli et al. 2017) and the comparison of these results with actual fossil preservation. Parry et al. (2017) even considered decay experiments of extant taxa a poor guide to fossilization by stating that 'in some cases, features that are decay resistant do not survive diagenesis, while others that are decay-prone preserve readily'. The authors (Parry et al. 2017, p.2) state that organic material can be preserved in various ways as carbonaceous compressions, via early (authigenic) mineralization in iron sulphide (pyrite) and apatite (calcium phosphate), and by early cementation or entombment, such as in concretions or within amber. These modes of preservation are based on very different pathways and processes during the often long time interval the fossilization process takes. Thus, primary preservation of organic material and subsequent secondary replacement and preservation as mineralic phases during diagenesis, metamorphism and weathering have to be differentiated to understand the fossilisation process.

Purnell et al. (2018) considered taphonomic experiments as an important aspect of fossil investigations and differentiated between fossilization and preservation, but used the terms soft tissues and non-biomineralized tissues interchangebly and even included sclerotized tissues, thus, essentially all organic or non-mineralized materials to describe organic preservation of fossils. The here presented research shows, however, that we need to be more careful in our observations and interpretations and use a precise terminology.

The various materials found in organisms lead to differences in their preservational potential and appearance of the fossils in the rocks. Also the type of sediment in which the organisms are burried leads to modifications of the fossil remains. Compaction, diagenetic changes and tectonic overprint alter the fossil remains subsequently and often the original organism is not recognizable any more or at least is difficult to interpret. This becomes more and more obvious the older the fossils are.

Interpretations of fossils of organisms not relatable to modern ones, such as the planktic graptoloids, are often based on a pre-existing focus of palaeontologists and were commonly misleading (Fig. 1E-G). The most prominent example of misleading interpretations in graptolite research may be the extrathecal tissue concept of Nancy Kirk (Fig. $1 \mathrm{G})$. Even though the idea is now regarded as erroneous (see discussion in Rigby 1993a), it had a considerable positive impact, as it stimulated an enormous amount of research and led to the understanding of Rhabdopleura zooids as useful models for graptolite zooids (Crowther 1981) and finally of the extant Rhabdopleura as a living graptolite (Mitchell et al. 2013). Also the early interpretation of graptolite colonies by Hall (1865) and Ruedemann (1895) (Fig. 1E) or the interpretation of muscle scars in graptolites by Haberfelner (1933) must be regarded as erroneous. They were based on genuine research, but incomplete understanding of graptolites at an early stage in their investigation (Maletz 2015). Ulrich \& Ruedemann (1931) even provided a detailed reconstruction of graptolite zooids (Fig. 1F) based on the assumption that graptolites were bryozoans and used their interpretation of supposed muscle scars in climacograptid graptolites as an argument. In this light it is understandable, that early palaeontologists even misinterpreted fossil material as graptolites, that were later recognized to represent eurypterids (Megalograptus: Miller 1874, Caster \& Kjellesvig-Waering 1955), phyllocarids (Coronagraptus: Hundt 1951, Dawsonia: Nicholson 1873) or trace fossils (Protovirgularia: M'Coy 1850, Nereograptus: Geinitz 1852, Triplograptus: Richter 1871). Modern interpretations of fossil graptolites (Fig. $1 \mathrm{H}, \mathrm{I})$ focus on the phylogenetic connection to the extant Pterobranchia and use the Rhabdopleura zooid (Fig. 1J) as a model for their interpretations (e.g. Crowther \& Rickards 1977, Melchin \& DeMont 1995, Rigby \& Sudbury 1995, Maletz 2015).

An interesting story of misidentification of graptolites also led to the name Graptolite Island for a small island in the South Orkney Island complex close to Antarctica (Dalziel 1979). The fossil material was initially identified as Ordovician graptolites by Gertrude Elles and published by Pirie (1905). The name for the island still exists and can be found even on Google Earth, but the fossils were later identified as Triassic plants.

\section{Terminology}

A serious problem in fossil preservation and taphonomy is the used terminology. Terms like 'soft-body preservation' and soft-tissue preservation' are used interchangeably and even the general term 'soft-body' would need a more precise definition. A typical example of the supposed 'soft body preservation' is the Herefordshire Lagerstätte, in which cuticularized fossils are preserved in three dimensions, filled with calcite (Briggs et al. 1996, Orr et al. 2000a, Siveter et al. 2007). None of the described taxa shows any preservation of cellular tissues, and Orr et al. (2000b) described even the most recalcitrant biological tissues as having been lost through decay. The specimens are external casts of the decayed specimens, filled with secondary sparitic calcite. Thus, no organic material is preserved and the term 'soft-body preservation' is completely misleading. 

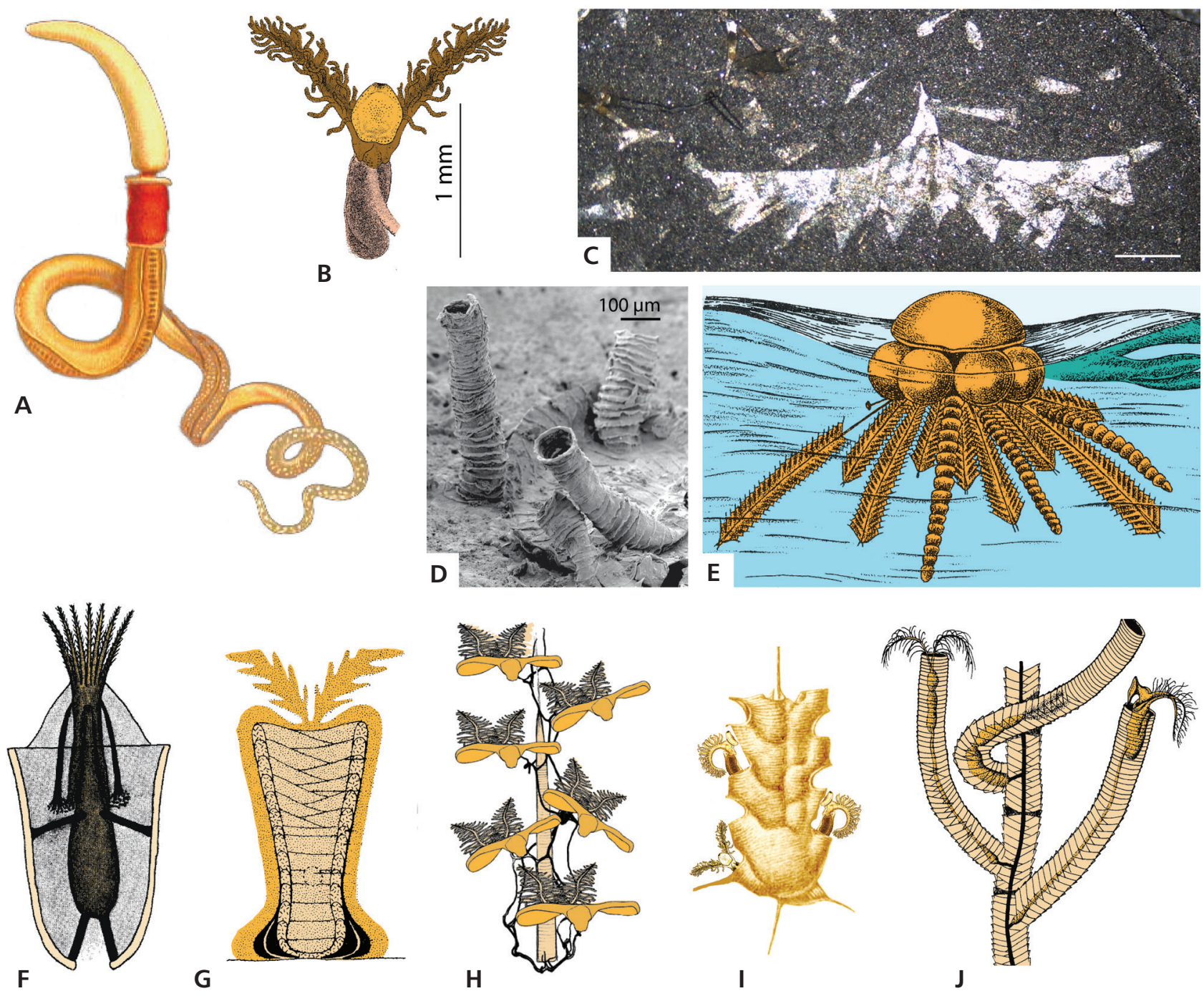

Figure 1. Preservation and interpretation of fossil and extant Hemichordata. • A - Saccoglossus kowalevskii (Agassiz, 1873), extant, drawing of specimen (adapted from Spengel 1893, pl. 1, fig. 10). B, D - Rhabdopleura sp., zooid, soft tissues; B - drawing of specimen (after Sars 1874); D SEM photo of tubarium, SMF 75727. - C - Expansograptus hirundo (Salter, 1863), NRM-PZ Cn 42824, Slemmestad, Oslo Region, Norway, Middle Ordovician, Dapingian. $\bullet$ E - graptolite colony with gonangia and pneumatophore (interpretation after Ruedemann 1895 ). $\bullet \mathrm{F}-$ interpretation of graptolite zooids by Ulrich \& Ruedemann (1931). $\bullet \mathrm{G}$ - extrathecal tissue model of Kirk (1979, fig. 3). $\bullet \mathrm{H}-$ Neogothograptus sp. with zooids following Melchin \& DeMont (1995), based on Kozłowska-Dawidziuk (2004). • I - Pseudamplexograptus distichus, small colony with zooids (based on Maletz 2015). $・ \mathrm{~J}$ - part of Rhabdopleura colony with zooids (after Dawydoff 1948, fig. 78). Illustrations not to scale.

A discussion on fossil preservation needs to separate between preservation of the original material, its somewhat geochemically modified remains (organic tissues and other organic matter; see hydrocarbons, etc.), or the replacement of tissues and other fossil material by secondary mineralisations. It is here suggested to use the term 'softtissue preservation' only for the preservation of cellular tissues and not for any replacement of these. The term tissues actually already indicates a cellular development (see Cambridge Academic Content Dictionary online). Thus, non-cellular materials should not be termed tissues. Following this guide, the carapace of arthropods cannot be called tissue, as it is an extracellular development as are clam and brachiopod shells, or - as a matter of fact - the tubaria of the Pterobranchia. These extracellular organic materials may be termed recalcitrant matter or recalcitrant material instead, as they represent more durable organic materials.

The general term or attribute 'soft' is misleading as the exoskeletons of arthropods can be quite soft during moulting stages, but harden later on and robust organisms may have much harder and thicker carapaces. Can these be called 'soft matter' or not is not a question. If any material of organisms can be called 'soft', it should be the cellular tissues. Cellular tissues however, are not preserved in most Palaeozoic fossil lagerstätten. It may even be questioned, 
whether the famous Precambrian embryos from China and other regions should be identified as soft. Steiner (2018, p. 96) discussed the preservation in soft-bodied fossil lagerstätten and considered that 'many Burgess Shale-type fossils may be considered as "soft-bodied" due to the weak state of cuticularization, but rarely preserve soft tissues'.

\section{Hemichordate preservation potential}

The hemichordates include two main groups, the Enteropneusta, worm-like animals and the often colony-forming Pterobranchia (Cephalodiscida and Graptolithina). The Enteropneusta are barely known in the fossil record (Cameron 2016, 2018) as they are represented essentially by soft-bodied, worm-like organisms and do not produce any durable (recalcitrant) materials. The Pterobranchia are a group of largely Palaeozoic organisms usually preserved as flattened films of organic material in mudstones and often in full relief in limestones. They include one of the most important groups of marine fossils in the early Palaeozoic, the planktic graptolites (Maletz 2014a, b, 2019a). Already Suess (1851, p. 88) discussed the preservation of graptolites and noted that they are not made of carbonate, but of organic material ('bituminöse Stoffe'). Maletz \& Steiner (2015), Maletz (2017, 2019a) and Beli et al. (2017) discussed the preservation of fossil and extant pterobranchs and differentiated three different materials, the organic tissue (cellular tissue; soft tissue) of the zooids (Fig. 2A, B), the stolon system (Fig. 2C) and the housing secretion or tubarium (non-cellular, recalcitrant matter, the fusellum and cortex of Maletz et al. 2014) (Fig. 2D, E), all having quite different propensity to decay. These, together with the entombing sediments, diagenesis, metamorphism and tectonics influence the preservation and interpretation of the fossils considerably. Thus, a general concept for the differentiation and preservation potential of these various organic materials needs to be established, that can be applied to all graptolites and compared to other organically preserved fossils. It is unlikely that different organically preserved fossils go through vastly different pathways of taphonomical change as the comparison of arthropod cuticle and graptolite fusellum indicates. Importantly, Gupta \& Briggs (2011) discussed the composition of fossil arthropod cuticles and graptolite tubaria, stating that both change considerably from their original composition and that these organic materials converge in composition during fossilisation towards aliphatic hydrocarbons due to maturation of the organic material (cf. Hartkopf-Fröder et al. 2015).

\section{Cellular tissues \\ (Enteropneusts/Pterobranch zooids)}

Enteropneusts and pterobranch zooids consist of cellular tissues and their fossil preservation may be termed soft body preservation. The enteropneusts are soft-bodied animals and are extremely rare in the fossil record (Boulter 2003, Caron et al. 2013, Maletz 2014b, Nanglu et al. 2016). They are found in a few fossil lagerstätten like the Burgess

\section{ZOOIDS} soft tissue
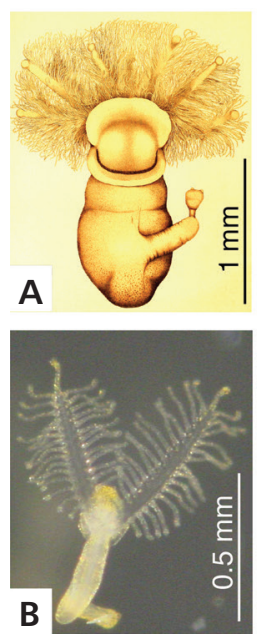

STOLON recalcitrant

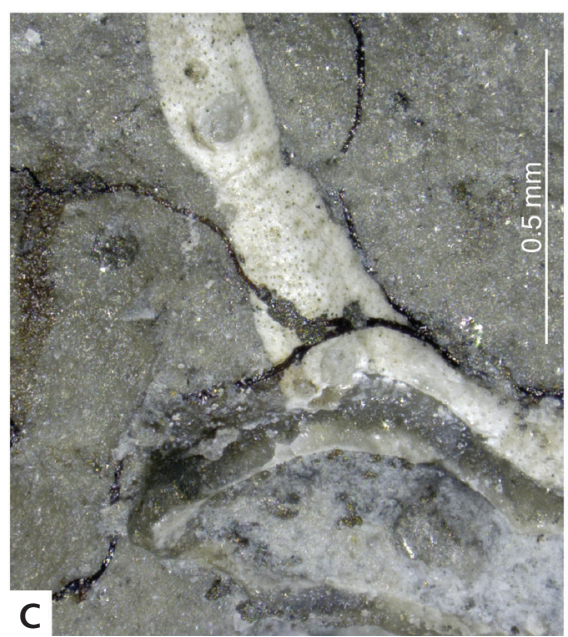

TUBARIUM recalcitrant

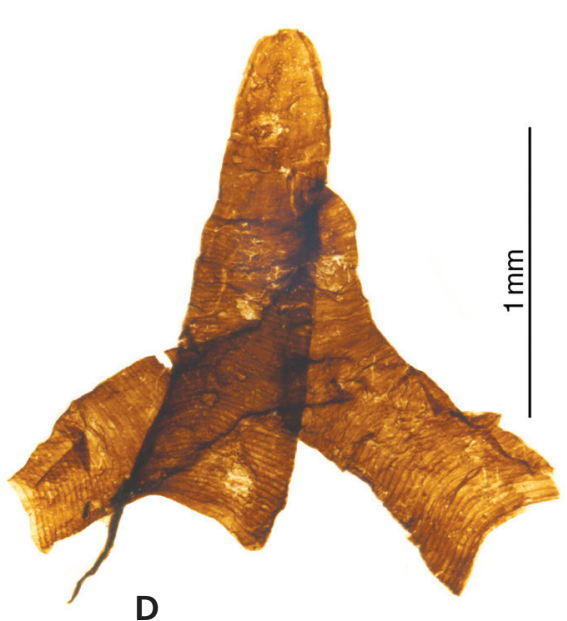

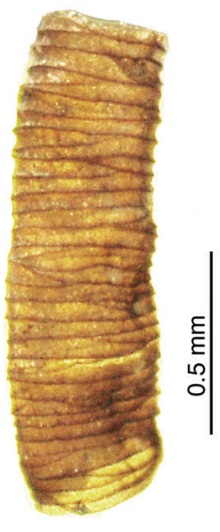

E

Figure 2. The organic materials of the Pterobranchia. • A - Cephalodiscus sp., zooid, drawing (after M'Intosh 1887, pl. 2). B - Rhabdopleura sp., zooid (Sato 2008). $・ \mathrm{C}$ - rhabdopleurid stolon (black lines) on hardground with bryozoan colony (white) (Keupp et al. 2016). $・$ D - Didymograptellus cowheadensis Maletz, 2010b, GSC 133396, bleached, showing fusellar construction. • E - Rhabdopleura sp., SMF 75776, partially translucent, brown tube showing fuselli, Ordovician, Öland, Sweden. 
Shale and the Mazon Creek fauna, but the preserved fossil remains usually lack detail of their anatomy. Extant enteropneusts are quite fragile and often break during the recovery as can be estimated through modern descriptions (e.g. Holland et al. 2012, 2013; Cameron \& Ostiguy 2013). This may indicate that even transport of the organisms through currents or in a sediment load may inflict considerable damage and makes their fossil preservation unlikely. The precise mode of preservation of the organic remains in the fossil enteropneusts from the Burgess Shale (e.g. Caron et al. 2013, Nanglu et al. 2016) is uncertain. Caron et al. (2013, supplementary information) indicated a carbonaceous preservation of Spartobranchus tenuis (Walcott, 1911), but did not prove it through an analysis. Ardunini et al. (1981) indicated the preservation of Megaderaion sinemuriense as an organic film, but did not provide more detail. Information on the preservational aspects of the enteropneusts from the Mazon Creek fauna (Maletz 2014b, Cameron 2016) are not available, but the material is preserved in weathered concretions and outlined by colour differences to the surrounding sediment. There is no evidence of the preservation of organic material in the pterobranch material, supported by the notion of Baird et al. (1986) that many Mazon Creek fossils are preserved as molds and composite impressions within siderite concretions. There are, however, also fossils in the Mazon Creek fauna, in which recalcitrant organic material is preserved (Clements et al. 2018). Megaderaion callovianum from the Callovian (Jurassic) of France (Alessandrello et al. 2004) is preserved as a pyritic relief specimen in most parts and the authors suggested that the trunk was covered by a segmented cuticle, a feature not known from extant Enteropneusta. Mesobalanoglossus buergeri from the Solnhofen Limestone is preserved in partial relief with a sediment fill of the gut (Frickhinger 1999), but details of the preservation are not available. There is no evidence of the preservation of organic material in the specimen. Thus, the preservation of fossil enteropneusts is quite variable and strongly depended on the sediments in which the material is found.

The zooids of the Pterobranchia are not known in organic preservation from the fossil record. Their bodies consist of various tissues including muscles, the nervous system, the skin and the intestines among others. None of these tissues is especially decay resistant and Beli et al. (2017) indicated that the zooids are completely decayed within 3-7 days (64-168 hours), supporting earlier information from Briggs et al. (1995). Obviously, the fast decay is also supported by the small size of the zooids, measuring a few millimetres at maximum (Fig. 2A, B). Durman \& Sennikov (1993) and Sennikov (2016) showed evidence of zooidal preservation in the middle Cambrian Sphenoecium obuti (Durman \& Sennikov, 1993), but anatomical details are not available. There is also no information on the (?)minerals involved in the mode of preservation of the putative zooids as no further investigation is available. Lower Ordovician specimens of the genus Psigraptus (see Rickards \& Stait 1984) have been indicated to show zooidal preservation, but the information is inconclusive. The stolons and zooids are apparently preserved as goethite infills or replacements (Rickards et al. 1991), probably originally formed from pyrite. Also the X-ray investigations of Bjerreskov (1978) of Silurian monograptids are inconclusive, as they show only vague and cloudy patches of minute pyrite crystals inside and around the apertures of the tubaria, but no evidence of zooidal anatomy. None of the supposed zooidal preservation in fossil graptolites preserves any traces of organic material. However, pterobranch zooids are well known from extant taxa and their anatomy has long been established (see compilation in Maletz \& Cameron 2016).

\section{The graptolite stolon system}

The stolon system (Fig. 2C) is a thickened and hardened cover of the gymnocaulus and forms the stolon system of the colonial pterobranchs (Graptolithina). It is probably secreted from the surface of the gymnocaulus, but the precise development mode is unclear even in extant taxa (Schepotieff 1904, Urbanek \& Dilly 2000). The stolon system is well known from the extant Rhabdopleura (Sars 1874, Lankester 1884, Schepotieff 1906, Maletz $\&$ Cameron 2016), but has also been found in the fossil state and has been described under a number of taxonomic names ( $c f$. Mierzejewski 1986, Maletz \& Beli 2018). The stolon is the part of the benthic graptolite that is most decay resistant. Even after an eight-month investigation interval, the stolonal pieces of the extant Rhabdopleura recondita investigated by Beli et al. (2017) were fully intact. Stolonal material is commonly preserved in dendroid graptolites (e.g. Mierzejewski 1986, Saunders et al. 2009, Maletz 2014a, Maletz \& Beli 2018) but appears to be lacking in most planktic taxa, probably evolutionarily absent or at least is not preserved and thus, taphonomically absent. An extremely wide stolon system appears to be present in the stem of the Middle Ordovician genus Mastigograptus (Bates \& Urbanek 2002). Jackson (1967) and Rickards \& Stait (1984) described remains of a (?)pyritized stolon system in the Tremadocian, Lower Ordovician genus Psigraptus. Hutt (1974) illustrated the stolon system in the early planktic Adelograptus tenellus from chemically isolated material as line drawings, but it has not been further investigated. A stolon system is not preserved in isolated specimens of the planktic Rhabdinopora flabelliformis described by Legrand (1974), suggesting that it may have been only weakly, if at all, sclerotized and was not preserved. 
Zalasiewicz et al. (2013) discussed a 'stolon-like system' in the planktic graptoloid Dicranograptus aff. ramosus as an abnormal recalcitrant pectocaulus or a stolon-like system. As an alternative interpretation, the authors suggested an infestation of colonial xenobionts. The investigation with the backscatter method at the scanning electron microscope (SEM BSE method) (Fig. 3A) shows that there is very little organic material left in this specimen. Unfortunately, a counterpart specimen was not available in which the complementary remains of the graptolite tubarium may have been found. It can be seen in many places along the specimen that the black fusellum covers pressure shadow minerals and this is visible only when the fusellum disappeared through splitting of the rock slab. Zalasiewicz et al. (2013, fig. 3) indicated this in a photo, stating that the original carbon flaked away and provided an unobstructed view onto the 'clay mineral template', herein interpreted as pressure shadow minerals, following Underwood (1992) and Page et al. (2008). The described hour-glass structures and other features do not represent a stolon system. As a stolon system, they should be preserved as a complete and un-interrupted strand of organic material, broken only in places where the organic material disappeared (see nema in proximal end of Fig. 3A), as it was connecting the zooids of the colony. The recognizable structures are preserved partly as clay minerals (as is normal for graptolites in the Southern Uplands), and partly as remains of organic material in the nema in the center of the biserial tubarium and as curved or 'hour-glass' like small organic remains that represent thickened parts of the thecal apertures and genicular rims. Associated specimens of Nanograptus phylloides (Fig. 3D, F, G) show the organic remains of their tubaria strongly affected by parallel fractures indicating considerable tectonic deformation. The majority of the fossil described by Zalasiewicz et al. (2013) represents remains of pressure shadow minerals ( $c f$. Underwood 1992) in a poorly preserved and strongly tectonized graptolite. Thickened genicular rims are clearly visible in a specimen of Dicranograptus spinifer investigated with IR-photography (Fig. 3E) and can be used to explain the described 'hourglass' like structures as preserved organic material and remains of pressure shadow minerals accumulated around these. These details are not visible in relief specimens of Dicranograptus (cf. Fig. 3C).

Loydell et al. (2004) illustrated specimens of Rastrites geinitzii (Törnquist, 1907) and ?Neolagarograptus sp. from the Llandovery of Latvia containing presumed parts of the contractile stalks (gymnocaulus). The remains are preserved as a two-dimensional film of organic carbon residues, surrounded by an early diagenetic pyrite fill of the thecal tubes. This is the only fossil evidence for the possible presence of a zooidal stalk in Silurian graptoloids, but not of the stolon system (see Maletz \& Cameron 2016).

\section{The pterobranch tubarium}

As the graptolite tubarium is the most commonly preserved fossil material known in graptolites, its construction ( $c f$. Bulman 1970, Maletz et al. 2016) is not discussed in detail here. The tubarium is formed from individual halfrings or full rings, the fuselli, and may be covered by a secondary material, the cortex or cortical tissue (e.g. Andres 1977, 1980; Crowther 1981). Its biochemical composition is still unclear (Foucart et al. 1965, Florkin 1969, Sewera 2011, Gupta 2013). Towe \& Urbanek (1972) suggested formation of the tubaria from polysaccharide-associated collagen-fibres on the basis of electron microscopic studies. It is generally found as a dark brown to black film of organic (carbonaceous) material, either flattened or in partial or full relief showing the complex shapes of the graptolite colonies. The presence of fuselli may be recognizable in specimens with thin fusellum or through the SEM BSE investigation and used to identify fossils as pterobranchs (Fig. 3B) (Zhang \& Erdtmann 2004a, b; Maletz et al. 2005; Maletz \& Steiner 2015). In chemically isolated graptolite material, the fuselli can be made visible through chemical bleaching (e.g. Maletz 1994) or through IR-microphotography (Melchin \& Anderson 1998), important measures to recognize questionable fossils as pterobranch remains (see Maletz et al. 2005, Maletz 2019a).

The decay of the fuselli of the pterobranch tubarium (Fig. 2D, E) is considerably slower than the decay of the zooids and leads to a much higher preservation potential of the graptolite tubaria. Indications of decay may be seen after a few days, but even after eight months, the tubes were largely intact. The tubes, however, became thinner and the fusellar rings were more pronounced, while aperturally some fusellar rings may have separated (Beli et al. 2017). Fuselli are still prominent in some well-preserved middle Cambrian pterobranchs, while in other specimens they cannot be recognized even though the general shape of the tubaria is preserved (see Sennikov 2016).

\section{Biostratinomy (Pre-burial modifications)}

Biostratinomy involves the early changes of organisms, death and mechanical changes in the distribution of the remains (Weigelt 1927), but the boundary to fossil diagenesis is difficult to define (Fernández-López \& Fernández-Jalvo 2002) and both may easily be combined (cf. Cai et al. 2010). Biostratinomy represents the earliest stages of fossil formation before the organism is buried in the sediment. Decay experiments (e.g. Sansom 2014, 2016; Butler et al. 2015; Nanglu et al. 2015; Beli et al. 2017) mimic this part of geological fossil alteration to understand fossil formation. Even the modification of 

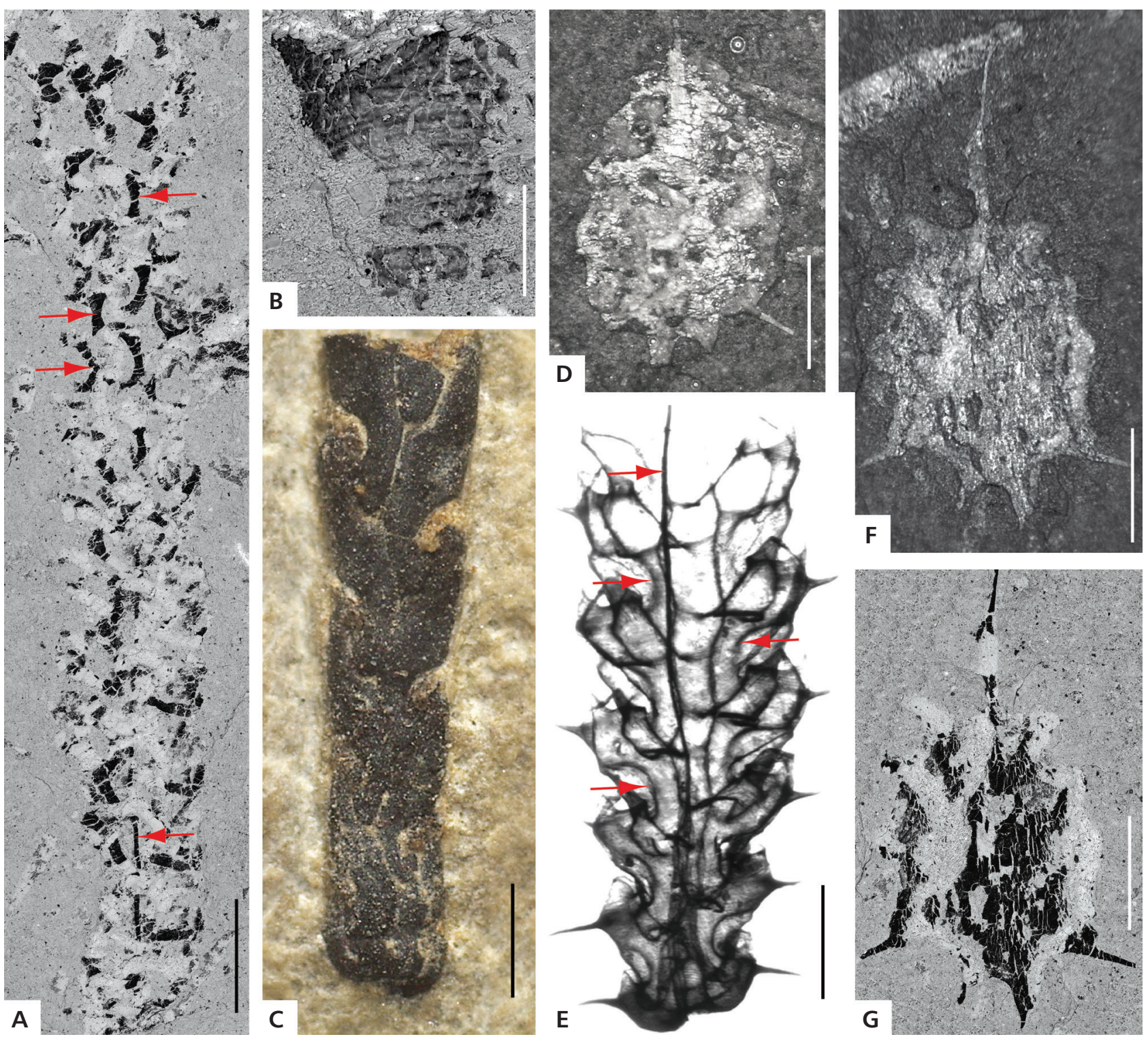

Figure 3. Graptolite preservation and investigation. - A - Dicranograptus cf. ramosus, GSE 5495, SEM-BSE photo showing remains of organic material, fusellum in black, pressure shadow minerals in light grey, sediment darker grey. B - Archaeocryptolaria longicornis Chapman, 1919, NMVP 13114, fragment showing fuselli, SEM-BSE photo (Maletz \& Steiner 2015, fig. 4g). C - Dicranograptus ramosus (Hall, 1847), NIGP 106259b, internal cast, relief specimen in reverse view (counterpart of Ge et al. 1990, pl. 18, fig. 11). D, F, G - Nanograptus phylloides (Elles \& Wood, 1908); D - GSE 5496, lectotype, light photo; F, G - light photo (F) and SEM-BSE photo (G) showing preservation of organic material (black) and tectonic fractures. E- Dicranograptus spinifer Elles \& Wood, 1904, IR-photo. Scale bars indicate $1 \mathrm{~mm}$ in each photo, except for (B), where it is $100 \mu \mathrm{m}$. Red arrows in (A) and (E) indicate preservation of thickened thecal apertural and genicular rims and nema in the specimens.

organic materials like cuticle and graptolite fusellum cannot be regarded as the result of decay resistance, but represents a diagenetic transformation within the sediment (cf. Gupta et al. 2006, Gupta \& Briggs 2011, Gupta \& Summons 2011).

Maletz (2017) discussed the biostratinomy of the pterobranchs in some detail and showed them to be useful for palaeoecological interpretations. Pterobranchs may be differentiated into benthic and planktic taxa. While the benthic taxa lived largely in shallow water regions and may be transported as fragments into deeper water settings, planktic taxa were more widely distributed and can be found in various sediment types. Fragments of benthic and planktic tubaria may have been transported for long distances before settling on the sea floor due to their durability. Depending on the sedimentation rates, they may have resided on the sea floor for some time before they were embedded in the sediment (Maletz 2017). Postmortem transport can be seen in often highly fragmented benthic taxa as they are found in deeper water successions, 
far from their living environment, but rarely in situ in places where they lived. Planktic taxa are commonly current oriented indicating the transport direction through their alignment (Maletz 2017, fig. 5.5). Information on the decay during this time is not available, but it may be noted that the zooids are not preserved. Cooper et al. (2012) discussed death assemblages of planktic graptolites, providing information on living associations and possible accumulations as indication of time averaging ( $c f$. Kowalewski 1996). Thus, not all graptolite tubaria found in a single layer of sediment may have been deposited at the same time instant, but may have accumulated during a longer time interval during which considerable changes may already have occurred to earlier deposited specimens (see also discussions in Rigby 1993b, Underwood 1998). Jones et al. (2002) interpreted clingfilm preservation in spiraliform monograptids as encasement of the graptolites by marine snow or microbial mats, indicating that graptolite tubaria may survive destruction for considerable time spans prior to burial and compaction.

\section{Diagenesis (Post-burial modifications)}

The material of the graptolite tubaria will be flattened into an organic film in most specimens, but sometimes early diagenetic processes or sediment fill prevent the flattening and the specimens may be preserved in full relief showing their original shapes. Most graptolites are preserved as flattened films and subsequently may have been modified by diagenesis, metamorphism and tectonics. All these changes may be independent of each other, but follow a directional path (Fig. 4). Two main paths of modification of graptolite tubaria can be differentiated: (1) preservation as uncompacted mineral-filled relief specimens and (2) post-compaction preservation as flattened films of organic material. Relief specimens (Fig. 4A, B, D, F, H) show early diagenetic mineral fills (Fig. 4B) before the entombing sediments are compacted, indicating an empty space in which the zooids may have decayed leaving space for the diagenetic mineral growth. At any time, these relief specimens may have been affected by maturation (Fig. 4D), deformation (Fig. 4F) or weathering (Fig. 4H), modifying the specimens, but these aspects act independently and are not mutually connected. Thus, for example specimens modified through deformation or weathering do not need to have been affected by diagenesis or maturation at an earlier stage.

The (now) compacted specimens also must have had an empty space inside initially (Fig. 4A), that was compressed during the compaction of the sediment, as there is no mineral or sediment fill in the tubaria. Their modifications follow the same paths seen in relief specimens (Fig. 4A, C, E, G, I). The two different paths in modification of the tubaria strongly affect the taxonomic identification of the graptolites. Flattened material often does not show the necessary details for a proper taxonomic identification at the species level as does the preservation in full relief in shale or limestones, but in relief specimens preserved in the rock, certain details may be covered in the sediment and, thus, not visible either. If the tubaria are later exposed on the sediment surface, they may easily be destroyed by weathering or even by bacterial degradation, but the latter has not been demonstrated so far even though Radzevicius et al. (2013) showed possible bacterial epibionts on Silurian monograptids.

\section{Tanning}

Wilson \& Butterfield (2014) hypothesized a process they called taphonomic tanning, the enhancement of recalcitrance of organic material due to cross-linking of structural biomolecules in arthropods, enhancing their preservation potential. They differentiated biological and abiological (taphonomic) tanning and noted a distinct effect of the sediment composition on the preservation of the cuticle of the polychaete Nereis. It is unknown whether this process might also enhance the preservation of pterobranch fossils. The dark colour of fossil graptolite tubaria may indicate that taphonomic tanning had a distinct effect on the pterobranch fusellum, as the tubaria of extant pterobranchs are usually colourless to light brownish (Maletz \& Beli 2018, fig. 3.4). Fossil graptolites often show a dark brown to black colour of the tubarium (Fig. $4 \mathrm{~B}, \mathrm{C})$ and the original translucence is lost. However, it is unclear whether this may be called tanning or is simply an effect of early diagenetic coalification of the organic material. The Burgess Shale-type preservation (BST), discussed by Wilson \& Butterfield (2014) as an example of biological and also sediment-induced taphonomic tanning, may alternatively be referred to a metamorphosis induced coalification due to the well-known greenschist metamorphosis of the Burgess Shale localities (see Powell 2003).

\section{Sediment and mineral fills}

A sediment fill of graptolites as it occurs in turbidite layers can prevent compaction of the specimens through the coarser-grained material being less susceptible to compaction. Thus, specimens of Levisograptus primus (Legg, 1976) from the Lower Head Sandstone of western Newfoundland (Maletz 2017, fig. 5.6) show full three-dimensional preservation as do many Silurian monograptids preserved in carbonates (Maletz 2017, pl. 15). More common, however, is the preservation of relief 


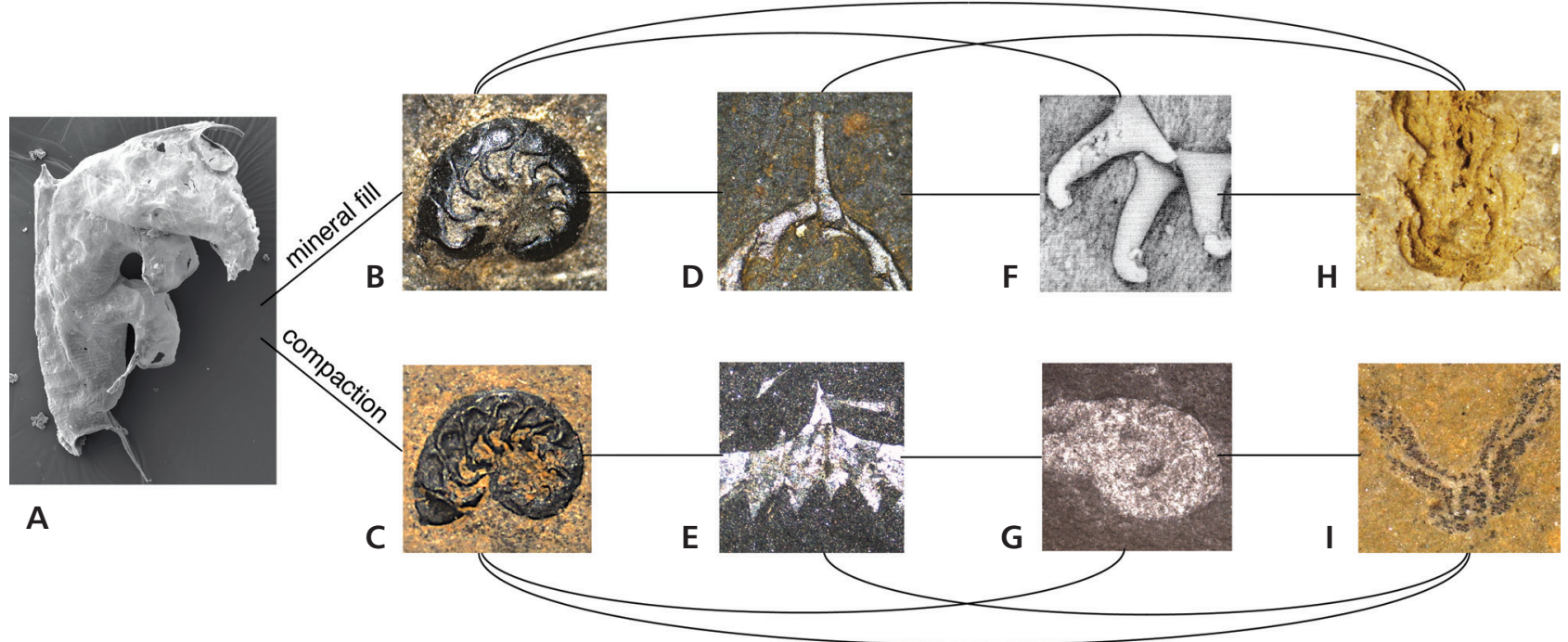

Figure 4. Taphonomical changes in graptolites. - A - Cochlograptus veles (Richter, 1871), PMU 31876, chemically isolated specimen, Dalarna, Sweden. • B, C, G - Cochlograptus veles; B - LO 1071t, relief specimen with surrounding pyritic halo, Kalholn, Dalarna, Sweden (Törnquist 1892, pl. 3, fig. 27); C - LO 1527t, flattened specimen, Röstånga, Scania, Sweden (Törnquist 1899, pl. 4, fig. 25); G - SMF XXIV 301, flattened, tectonized, showing parallel fractures and pressure shadow minerals, Raitzhain, Thuringia. • D - Didymograptus artus Elles \& Wood, 1901, PMO 234.062, coalified relief specimen, Slemmestad, Norway. - E - Expansograptus hirundo (Salter, 1863), NRM-PZ Cn 42824, flattened and coalified specimen, Slemmestad, Norway. $・ F$ - Demirastrites triangulatus (Harkness, 1851), showing displaced, pyrite-filled thecae, central Wales (Palmer \& Rickards 1991, pl. 74). $• \mathrm{H}-$ Pseudoclimacograptus formosus var. nana Ge \& Yin in Mu et al., 1962, NIGP 10856, relief specimen, partly weathered tubarium fill, Chilianshan, China. • I - Jiangxigraptus inculus Ge in Ge et al., 1990, NIGP 106213a, Ningxia, China, flattened, fractured specimen (see Ge et al. 1990, pl. 27, fig. 7). Specimens not to scale.

specimens in mudstones, the so-called 'Graptolite Shales'. In these cases, the specimens must have been filled with early diagenetic minerals before the compaction of the surrounding shales (Figs 4B, 5A). In most cases, this mineral is pyrite (Fig. 5F, H) and pyrite-filled graptolites are quite common, but often the pyrite is weathered to limonite or iron hydroxide (Fig. 5I) due to subsequent surface weathering and the original composition of the cast might be difficult to establish. Sometimes even the fusellar construction can be visible on the surface of the internal pyritic molds (Fig. 5H). Underwood \& Botrell (1994) discussed the pyrite formation of graptolites in some detail and Blackett et al. (2009) illustrated steinkerns of graptolites, comparable to the ones previously investigated by Törnquist (1893) (Fig. 5F).

Bjerreskov $(1978,1991,1994)$ discussed the pyrite fill of Silurian (Llandovery) graptolites of Bornholm as early diagenetic and found that pyrite was rare on the outside of the tubaria. Cavities within the graptolites also included stalactite-like forms of pyrite suspended from the roof of the tubaria. These and geopetal layering of pyrite framboids indicates the very early formation of the pyrite within the graptolite tubaria. Törnquist (1893) illustrated a number of beautiful specimens of biserial graptolites from the Silurian shales of southern Sweden as drawings. His material was preserved in full relief filled with pyrite (Fig. 5F) with the fusellum preserved as a thin mantle around the mineral fill and inside as the interthecal septa, the median septum and the nema. He sectioned the specimens and polished them to show the internal parts. Very good preservation can be seen in graptolites covered by a thin layer of pyrite in carbonates (Fig. 5D, E), which may be invisible in non-isolated material.

As a rare example of mineral fills in graptolite tubaria, phosphate was discussed by Goldman \& Bergström (1997) forming molds of Climacograptus putillus (Hall, 1865) and Rectograptus peosta (Hall, 1861) at Graf, Iowa. The specimens are found in the brown shale facies of the Elgin Member of the Maquoketa Formation. In fresh material, the black fusellum of the specimens is still preserved, but quickly disappears through weathering.

Maletz (2009) described Middle Ordovician graptolites chemically isolated from limestones of the Quebec Appalachians. The specimens were preserved in three dimensions, but in part covered by irregularly grown silica crystals, protecting them from destruction. It is apparent that the specimens were already broken in part due to tectonic distortion, but the parts of their organic tubaria were kept together by the silica overgrowth (Fig. 5M). Even better preserved are the Silurian graptolites from cherts described by German scientists (Hundt 1934, 1946, 1957; Horstig 1952; Richter 1948, 1951; Münch 1951). 
Silurian chert pebbles with graptolites were found in a number of secondary deposits of glacial or glacio-fluvial origin in Germany. A detailed investigation shows a thin inner and outer cover of the preserved organic tubaria with white silica (Greiling 1958). Even though originally described as silicified, the material clearly shows that the tubaria were covered or coated by early diagenetic silica (Fig. 5G) before any compaction happened and the organic material is well preserved. The tubaria may in part be filled with sediment, but also specimens completely filled with white silica have been discovered.

The early formation of carbonate concretions as in the Silurian Kallholn Shale Formation of Dalarna, Sweden, can preserve graptolites in three dimensions (Hutt et al. 1970; Loydell 1991; Loydell \& Maletz 2004, 2009), while in the surrounding mudstones, the same graptolite species are completely flattened (see Walasek et al. 2019). The same effect appears to be responsible for the beautiful preservation of graptolites in glacial boulders of northern Germany and Poland (e.g. Heidenhain 1869; Eisenack 1951; Kozłowski 1962; Urbanek 1958; Maletz 2008, 2010a; Maletz \& Schöning 2017; and many more) or the beautiful retiolitids and other graptolites described from Arctic Canada (e.g. Lenz \& Melchin 1987, Lenz $\&$ Kozłowska 2006). This material is generally so well preserved that it is possible to chemically isolate the specimens from the sediments and investigate them in three dimensions to understand their construction.

\section{Compaction}

Burial may not have altered graptolite morphologies considerably, unless the tubaria are compacted. Due to the compaction of most sediments, the specimens have been flattened into a double layer of organic material without much change of the outline of the specimens. As the graptolite tubaria were made from flexible organic material, the compaction led to wrinkle effects (Fig. 5K), not noticeable on flattened specimens in mudstones, but more recognizable in material chemically isolated from the sediment. These wrinkles can easily be differentiated from the fusellar construction by their irregular position and short lengths. Wrinkles are common also in other organically preserved, flattened fossils as the example of a Silurian naraoiid from Canada (Caron et al. 2004) shows.

There appears to be no significant lateral expansion of the tubaria (see Briggs \& Williams 1981, Williams et al. 1982) due to the pressure of the sediment from all sides on the entombed specimens. Changes in the dimensions are generally been attributed to tectonic deformation and no analysis exists to show with certainty lateral extension of undeformed material. Flattening of graptolite colonies (Fig. 5K) leads to the projection of several layers of the fusellum (incl. interthecal septa and median septa) into a single plane. Therefore, the three-dimensional development of the tubarium is difficult to reconstruct or it might be impossible to recognize certain important taxonomic features. It might even be impossible to identify dextral and sinistral development in these specimens. However, in cases when the fusellum is thick, some details may still be recognizable (Fig. 5L).

\section{Coalification (maturation)}

Coalification or maturation of the graptolite fusellum, or graptolite reflectance, has been investigated thoroughly due to the interest of the oil industries (Figs 6, 7). Coalification is achieved through heating of the organic material within the sediment, usually by an increasing depth gradient through deposition of sediments in a subsiding basin during regional metamorphism, or through contact metamorphism from magmatic intrusions and associated heating of the host sediment. Both can happen without the effects of tectonic action such as folding and faulting, but often is associated with these and it may be difficult to separate the real cause of some of the metamorphic changes in the fossil material.

Graptolite reflectance is used commonly in Palaeozoic sediments to determine the thermal maturity of sediments and can be correlated with other maturity parameters, especially the vitrinite reflectance used commonly in coal geology. The thermal alteration of the graptolite fusellum follows closely the alteration of other organic materials

Figure 5. Diagenetic effects on graptolites. - A, B, G - Monograptus priodon (Bronn, 1835); A - SMF 75780, relief specimen, filled with pyrite, glacial boulder, Germany; B - SMF 75780, coated with ammonium chlorite to show fuselli; G - SMF XXIV 401, relief, coated by silica in chert (see Greiling 1958, fig. 7). $・$ C - Rhaphidograptus toernquisti (Elles \& Wood, 1906), Bornholm, x-ray photo, showing pyritic clouds at thecal apertures (from Bjerreskov 1978, pl. 21, fig. 3). D, E - Amplexograptus perexcavatus (Lapworth, 1876) SMF 75778, isolated specimen showing pyrite overgrowth (detail in E). $・ \mathrm{~F}$ - Rivagraptus bellulus (Törnquist, 1890), LO 1128t, pyrite fill, sectioned. $\cdot \mathrm{H}-$ Adelograptus tenellus (Linnarsson, 1871), LO 2257t, Scania, pyritic internal cast showing fuselli (see Westergård 1909, pl. 5, fig. 20). • I - Cymatograptus bidextro Toro \& Maletz, 2008, IANIGLA-PI 1810, pink mineral fill (Toro \& Maletz 2008, fig. 7.6). J - Desmograptus micronematodes (Spencer, 1884a), stolon system in relief (from Saunders et al. 2009, fig. 3). K - Holmograptus sp., GSC 140108, bed WBS 52, Cow Head Group, flattened, chemically isolated, showing wrinkles due to flattening. - L - Acrograptus sp., NRM-PZ Cn 2191, nearly flattened specimen in green shale, Dalarna, Sweden. • M - Archiclimacograptus decoratus (Harris \& Thomas, 1935), proximal end covered in silica, GSC 133529, Les Méchins, Quebec, Canada. Scale bars indicate 1 mm unless differently indicated. 
Jörg Maletz • Hemichordata (Enteropneusta \& Pterobranchia, incl. Graptolithina)
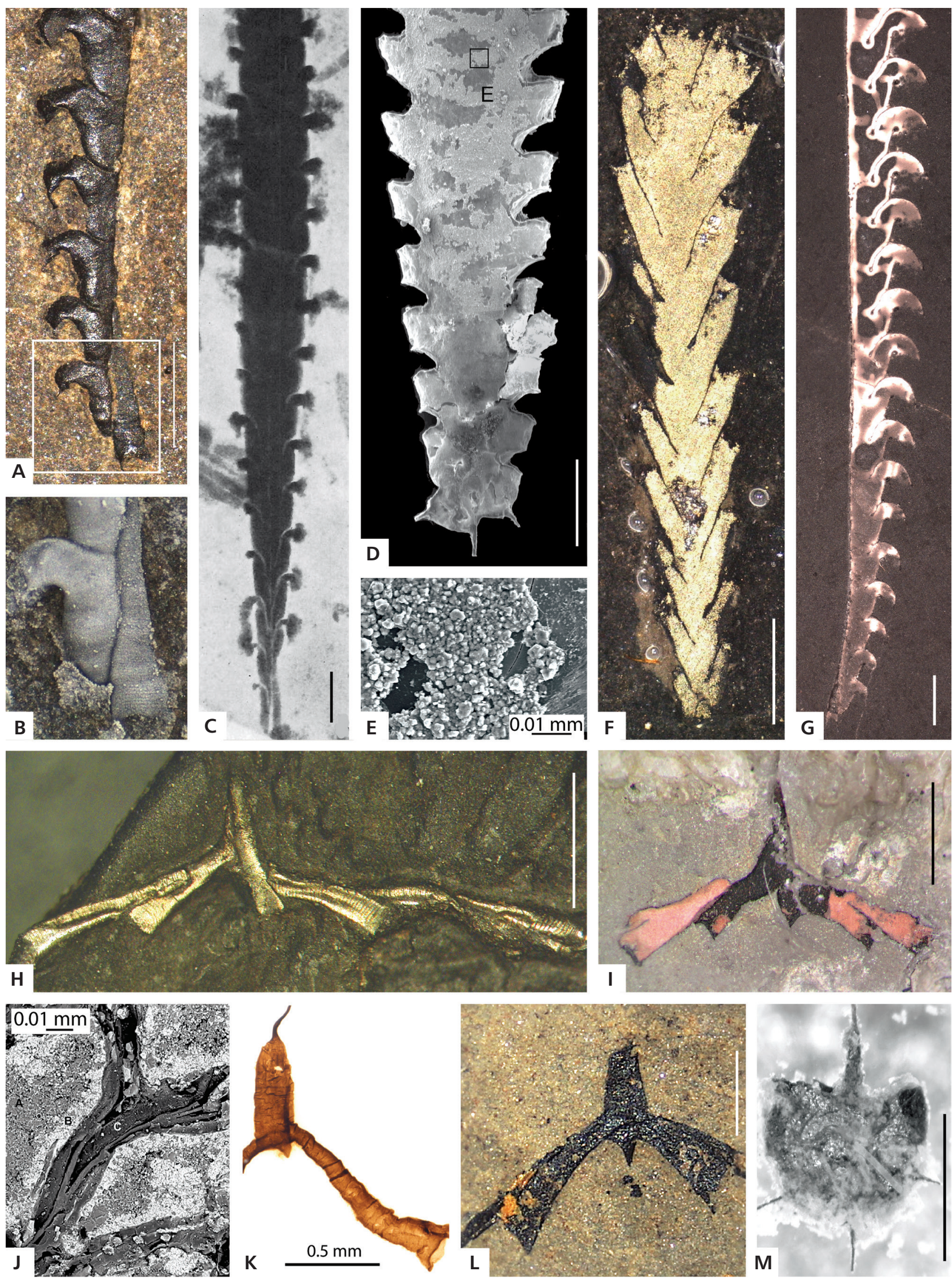


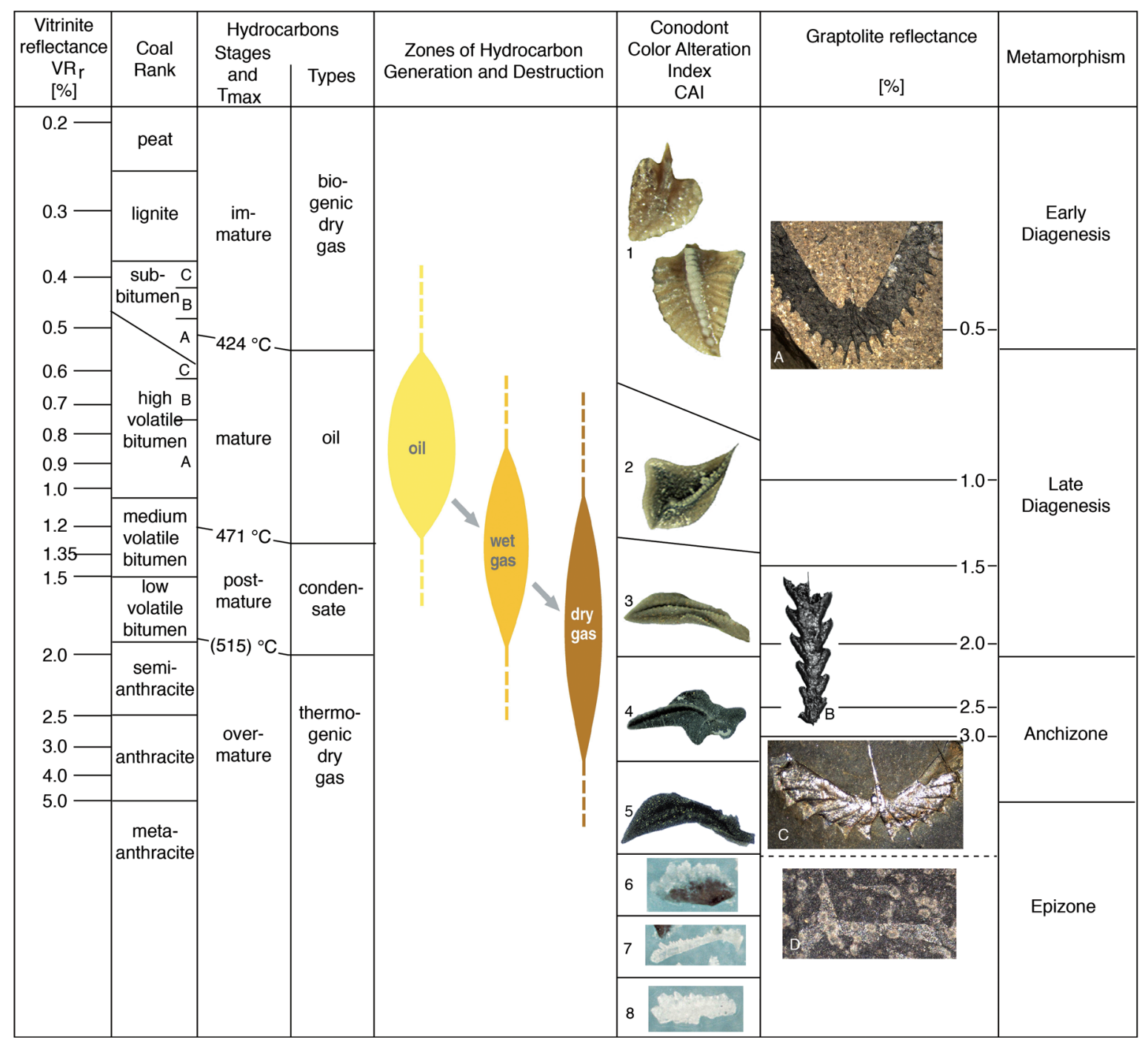

Figure 6. Diagram showing correlation of vitrinite reflectance with other thermal maturity parameters including graptolite reflectance and metamorphic stages (based on Hartkopf-Fröder et al. 2015, fig. 26; Voldman et al. 2008). Conodont specimens from Hartkopf-Fröder et al. (2015) to demonstrate CAI values. Graptolites: A - Parisograptus imitatus (Harris, 1933), GSC 139246, Cow Head Group, western Newfoundland; B - Orthograptus apiculatus Elles \& Wood, 1907, PMU 35732, Gullhögen Quarry, Billingen, Västergötland, Sweden; C - Isograptus rigidus Maletz, 2011, PMO 234.063, Slemmestad, Oslo Region, Norway; D - Baltograptus geometricus (Törnquist, 1901), LO 1585T, lectotype, Diabasbrottet, Hunneberg, Sweden. Specimens not to scale.

and its investigation is valued for the understanding of oil and gas generation in graptolite bearing rocks. The effect of thermal alteration is very similar to the coalification of plant material and even arthropod cuticles and other organic material (Hartkopf-Fröder et al. 2015). The optical properties of the graptolite fusellum change considerably with increasing temperature (Teichmüller 1978, Goodarzi 1990, Hoffknecht 1991, Inan et al. 2016, Schmidt-Mumm \& Inan 2016). Progressive colour changes as are apparent in conodonts (CAI - Colour alteration index: Epstein et al. 1977, Königshof 2003, Hartkopf-Fröder et al. 2015), in ostracods (Ainsworth et al. 1990) and other, mostly

Figure 7. Maturation of graptolite fusellum. • A - Haddingograptus eurystoma (Jaanusson, 1960), NIGP 157476, full relief, Saergan Fm., NW China (see Chen et al. 2016). • B - Dicellograptus johnstrupi (Hadding, 1915), PMU 35733, Bestorp, Västergötland, coll. Törnquist, relief in obverse view. • C - Cymatograptus undulatus (Törnquist, 1901), NRM-PZ Cn 1207, Norway, flattened. • D - Parapetalolithus conicus (Bouček, 1932), SMF 68214, G-14 borehole, flattened, thick fusellum, highly coalified, showing indications of fuselli (Maletz 1997, fig. 5f). E - Expansograptus hirundo (Salter, 1863), PMO 234.064, low relief, highly coalified, Slemmestad, Norway. $・ F, G-$ Expansograptus sp., PMU 31878/1, 2, preserved part as cast, part as imprint, showing mineral growth (greenish dots) in contact metamorphous sediment, Diabasbrottet, Västergötland. $\bullet \mathrm{H}-$ Baltograptus geometricus 

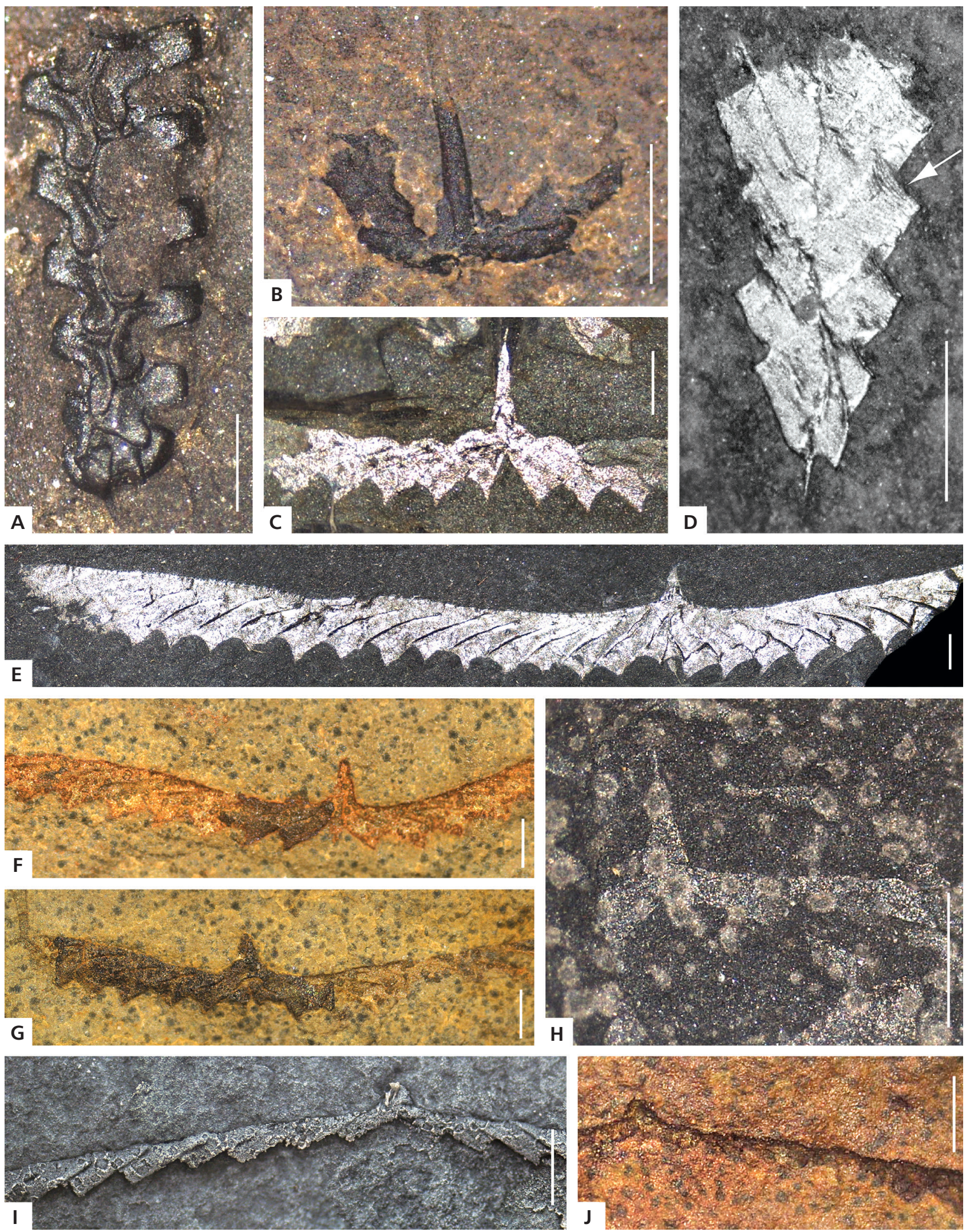

(Törnquist, 1901), LO 1585T, holotype, showing metamorphous minerals in sediment, Diabasbrottet, Hunneberg, Sweden. • I, J - Baltograptus sp., PMU 23163B, latex cast (I) and mold (J) of highly contact metamorphosed specimen showing poor preservation and preserved mineral imprints on latex cast, Diabasbrottet, Hunneberg, Sweden. Scale bar indicates $1 \mathrm{~mm}$ in each photo. 
organic fossils, have not been established for graptolites, even though some changes are easily recognizable in the field. A general trend can be seen in graptolite samples from low reflectance typically found in the Cow Head Group of western Newfoundland to high reflectance typical for the Oslo Region of Norway. It can easily be correlated with the CAI of the conodonts in associated sediments (Figs 6, 7).

Unaltered or weakly altered fossil graptolite material is dark brown to black in colour as specimens from many regions indicate (Fig. 7A, B). These graptolites consist of supposedly thermally unaltered fusellum as typically found in the Cow Head Group of western Newfoundland (Williams \& Stevens 1988), where the CAI of the sediments is between 1.0 and 1.5 (Stouge 1986, Nowlan $\&$ Barnes 1987). It changes to an intense silvery shine as examples from the G-14 drill core $\mathrm{N}$ of the island of Rügen, Baltic Sea (Fig. 7D) and the Ordovician of the Oslo Region, Norway show. The Norwegian graptolites from the Tøyen Shale Formation and Elnes Formation show a strong silvery shine of the fusellum (Fig. 7C, E), while conodonts associated in the succession have a CAI of 5 (Bergström 1980). This colour in the graptolites can easily be mistaken for a pyritization (and has been), especially in relief specimens filled with pyrite. In these specimens, the construction of the tubarium may still be recognizable through the presence of interthecal septa and crossing canals (Fig. 7E), but in many specimens only the outline may be seen (Fig. 7C). Sometimes even the fuselli are preserved, especially in specimens or species with robust thecal walls and little cortical overgrowth (arrow in Fig. 7D).

At higher temperatures, mineral growth in the sediments may partly destroy the graptolites, but the remains of the fusellum can be recognized and the outline reconstructed even in flattened specimens (Fig. 7H). In this flattened specimen from Mt. Hunneberg, the growth of metamorphic minerals in the sediment is clearly visible. Graptolites, thus, still preserve their fusellum in early epizone metamorphism, but at higher temperatures, the fusellum might disappear. With increasing temperatures, the dark mudstones get lighter, the graptolite fusellum darkens to a brownish colour and starts to disappear (Fig. $7 F, G)$. At this point, the specimens may appear like faint imprints. Only in parts of the tubaria filled with pyrite, the full outline and shape may be discernable (Fig. 7G) before the fossils disappear completely. In partial relief specimens, the relief part may be preserved and in higher metamorphic grades even imprinted outlines of metamorphic minerals may be found on the graptolite casts (Fig. 7I, J). Hoffknecht (1991) indicated values of CAI 6 for samples close to the contact of a dolerite dyke at Mt. Hunneberg, Sweden, where poorly preserved graptolites were still present (see section in Egenhoff \& Maletz 2007, fig. 3). The exact temperature of the disappearance of the graptolite fusellum has not been estimated and would need more research. It is not clear whether there are differences in preservation between contact metamorphosed and regionally metamorphosed material.

Dieni et al. (2005) reported well-preserved graptolites from greenschist metamorphic facies in the southalpine metamorphic basement and stated that the fusellum is heavily cracked, but undeformed. A thin section shows the relief specimens filled with (?)silica. The documented fracturing of the tubaria, however, should indicate a certain degree of deformation that might be difficult to see with the naked eye. Considerable resistence of graptolite tubaria to contact metamorphism and deformation was demonstrated by Štorch \& Kraft (2009, fig. 3), showing that graptolite specimens can be assigned to a genus even in chiastolitic porphyroblastic slates.

\section{Tectonic deformation}

Tectonic deformation of graptolites is often easy to recognize (Figs 8,9) and was described quite early in graptolite research, as the examples of Richter (1853) and Eisel (1908) show. In pyritic relief specimens, however, it may be difficult to detect (Fig. 8A, B). Tectonic deformation can be quite severe and specimens stretched in different directions may appear to belong to separate

Figure 8. Tectonic deformation. • A, B - Archiclimacograptus wilsoni (Elles \& Wood, 1906), SMA 19619, Dob's Linn, Scotland, showing coalified fusellum (silvery in A) with parallel fractures (more easily visible in B, coated) indicating low tectonic deformation. $\bullet \mathrm{C}-$ Baltograptus jacksoni Rushton, 2011, BGS Ht 1260a, holotype, showing pressure shadow minerals (orange) and complete, apparently undistorted fusellum in partial relief proximal end, arrows indicate largely covered pressure shadow minerals in proximal end. $\bullet$ D - Normalograptus normalis (Lapworth, 1877) relief specimen, filled with pyrite, surrounded by strong pressure shadow minerals, Llandovery, Wales (from Palmer \& Rickards 1991, pl. 30). E - Cryptograptus sp., Korpa, Bolivia, showing dark fusellum and high amount of yellowish pressure shadow minerals, Nordenskjöld collection, Riksmuseet, Stockholm (photo by E.D. Brussa, Cordoba, Argentina). - F - Orthograptus sp., drill core, New York State, silvery shining fusellum and blue pressure shadow minerals. • G - ?Rickardsograptus thuringiacus (Kirste, 1919), SMF XXIV 222, Raitzhain, Thuringia, coll. Hemmann, specimen with thick fusellum showing parallel fractures, some white pressure shadow minerals visible. $\bullet \mathrm{H}-$ Diplacanthograptus spiniferus (Ruedemann, 1912) showing green mineralization, SMF number needed JM115, Agort Chert, plate E, HD Range, Nevada, coll. J. Riva; Quebec City, Canada (see Riva 1970, p. 2712). I - Anomalograptus reliquus (Clark, 1924), SMF-JOS 23.1a, Sandia Region, Peru, strongly tectonically distorted specimen, see tectonic wrinkles in mudstone. Scale bars indicate $1 \mathrm{~mm}$ in each photo, unless indicated otherwise. 

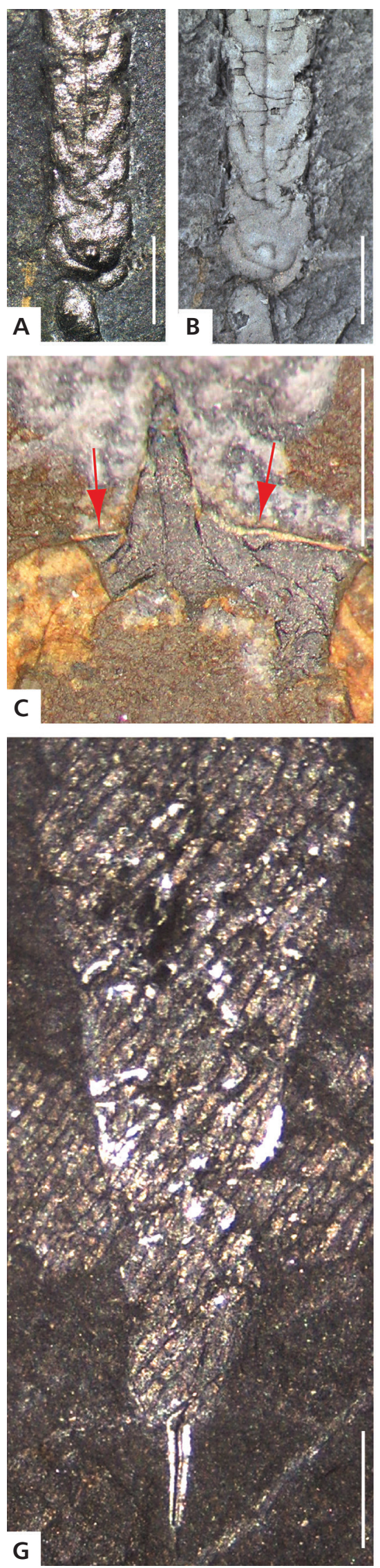
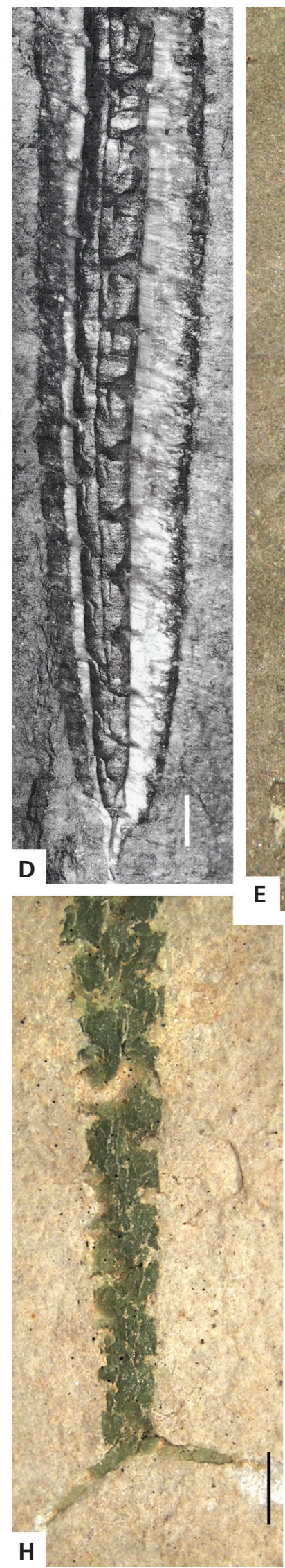
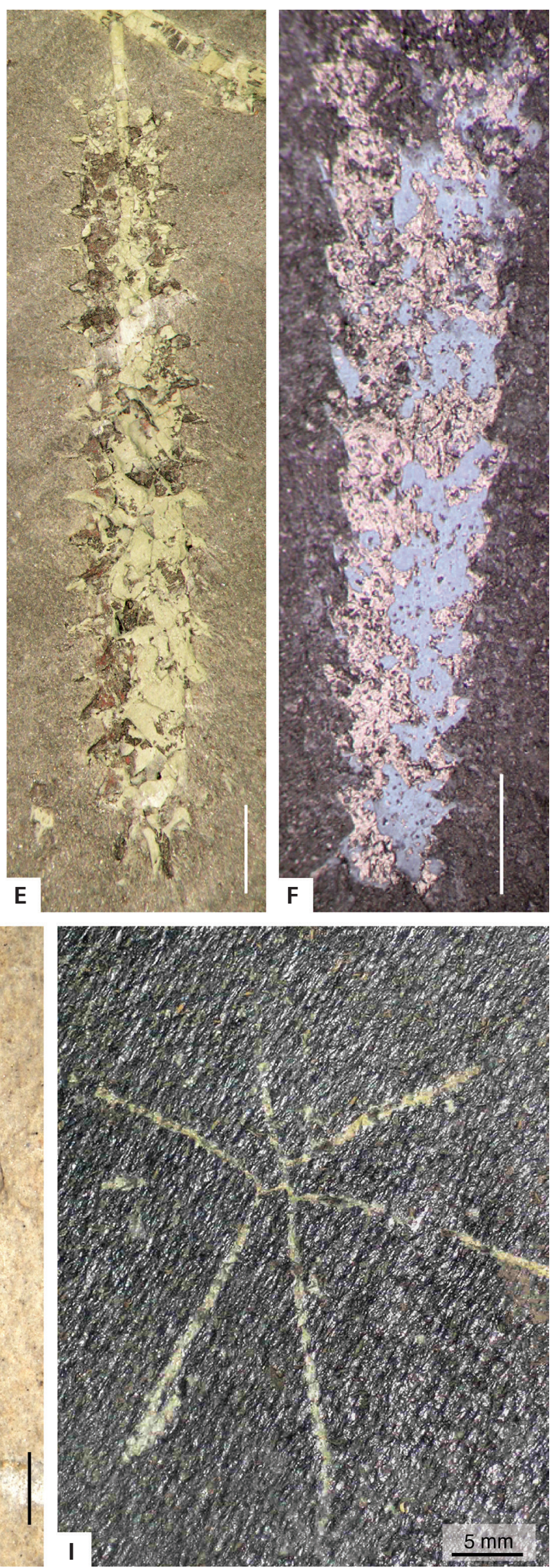
species (e.g. Gortani 1922, Schauer 1971, Maletz et al. 1998). Eisel (1908) showed this especially well from specimens bent or curved at various degrees. He warned against identifying graptolite specimens without the understanding of the effects of tectonic deformation. In many strongly deformed specimens the deformation can be seen through the parallel fractures in the fusellum (Fig. 8G) as discussed by Mitchell et al. (2008) for material from Bolivia. This fracturing may appear only in more strongly deformed specimens and is related to the thickness of the fusellum.

Richter (1853) described the graptolites of Thuringia as often preserved as fibrous, silvery white to greenish minerals, that Geinitz (1852) had already identified as talcum. Gümbel (1868) identified the mineral as a pyrophyllite and compared it with the minerals surrounding many Carboniferous plants. Kobell (1870) described the mineral as gümbelite, but the name has rarely been used outside of Germany. Underwood (1992) compared the preservation of graptolites with the preservation of plant fossils from the Carboniferous of Hartland Quay. The same preservation can be seen in the Carboniferous flora from Piesberg, Germany (e.g. Krings \& Kerp 2006) and gümbelite preservation was recently noted in associated insect fossils from this locality (Brauckmann \& Herd 2002, Dunlop et al. 2008).

These chloritic minerals were identified as pressure shadow minerals by Underwood (1992), formed around the organic material during tectonic deformation (Fig. $8 \mathrm{C}-\mathrm{F}$ ) of the sediments due to the differences in the composition and reactivity of the sediment and the organic material of the fossils. The colour of these chloritic minerals may vary considerably and range from white to yellow (Fig. 8E, I), reddish (Fig. 8C), blue (Fig. 8F) and green (Fig. $8 \mathrm{H}$ ). These pressure shadow minerals can be regarded as the most important feature for recognizing tectonically deformed graptolites. They often show the direction of tectonic deformation through the lineation (Fig. 8D, G) in the fibrous minerals (see Mitchell et al. 2008). The deformation may also be seen in fracturing of the graptolite fusellum (Fig. 8G) and the lineation in strongly deformed rocks (Fig. 8I) when the graptolites are barely identifiable (see Schauer 1971). Thus, deformed graptolites can be used to measure finite strain and volume loss in sedimentary rocks (e.g. Hills \& Thomas 1944, Wright \& Platt 1982, Jenkins 1987, Goldstein et al. 1998). Sherlock et al. (2003) even used pressure shadows (strain fringes) around pyritic casts of basal Silurian graptolites to date the Acadian orogeny in the Welsh Basin.

The graptolites from the Upper Ordovician of Dob's Linn, Scotland show a 'striking white preservation' as pressure shadow minerals (Underwood 1992, p. 183), as can easily be seen also in the illustrations of Williams (1982). Williams (1981, pl. 2, fig. 4) indicated considerable tectonic deformation of graptolites from Dob's Linn, but did not describe the tectonic lineation of the fusellum in this material. Page (2007) and Page et al. (2008) discussed the preservation of the graptolites from Dob's Linn and compared the preservation with the Burgess Shale. The low-grade metamorphic rocks of Dob's Linn and the Burgess Shale show the close association of fossils with distinct phyllosilicates interpreted by Page (2007) as clay templates. A closer look at the geology of the regions shows that the geological history includes not just heat related metamorphism, but also considerable tectonic deformation, folding and faulting of the rocks that modified the fossil appearance. The Dob's Linn locality shows imbricate-thrust slices of the upper Ordovician Moffat Shale Formation in a terrane composed largely of the Silurian Gala Greywacke Group in which the Ordovician/ Silurian GSSP with its important graptolite faunas can be investigated (e.g. McKerrow et al. 1977; Williams 1979, 1982).

Meyer et al. (2018) discussed 'exceptionally preserved soft-bodied problematica' from the Martinsburg Formation of Pennsylvania and showed the strong tectonic deformation of the associated graptolites. The graptolite fusellum is preserved as organic films, but is heavily fractured (Meyer et al. 2018, fig. 3). The associated problematica are largely found as poor remains of fractured organic particles (Meyer et al. 2018, fig. 4) surrounded by pressure shadow minerals. The rocks are of anchizone metamorphic grade, as the illite crystallinity and the CAI of 4.5 indicate. Thus, the preservation of the Martinsburg succession demonstrates strong thermal alteration and tectonic deformation of the included graptolites.

It has not been investigated when the formation of pressure shadow minerals starts around the graptolites or can be recognized with the naked eye, but pressure shadow minerals already appear in sediments when the organic tubaria of the graptolites do not yet show any tectonic deformation through cracks in the fusellum, especially in relief or partial relief specimens filled with pyrite. The holotype of Baltograptus jacksoni Rushton, 2011 shows an undeformed proximal end in partial relief with preserved fusellum. The distal parts of the stipes are lost and the surrounding pressure shadow minerals are visible. These also surround the proximal end as a thin line (Fig. 8C, arrows). The pressure shadow minerals can reach considerable thicknesses in relief specimens (Fig. 8D). Only at a higher degree of deformation is the development of pressure shadow minerals associated with fracturing of the fusellum, at least in flattened specimens.

Robust relief specimens of biserial graptolites filled with pyrite may resist the tectonic deformation more easily, while monograptid forms with slender prothecae may be broken into individual, slightly displaced thecae (see Sudbury 1958; Palmer \& Rickards 1991, pl. 74). 

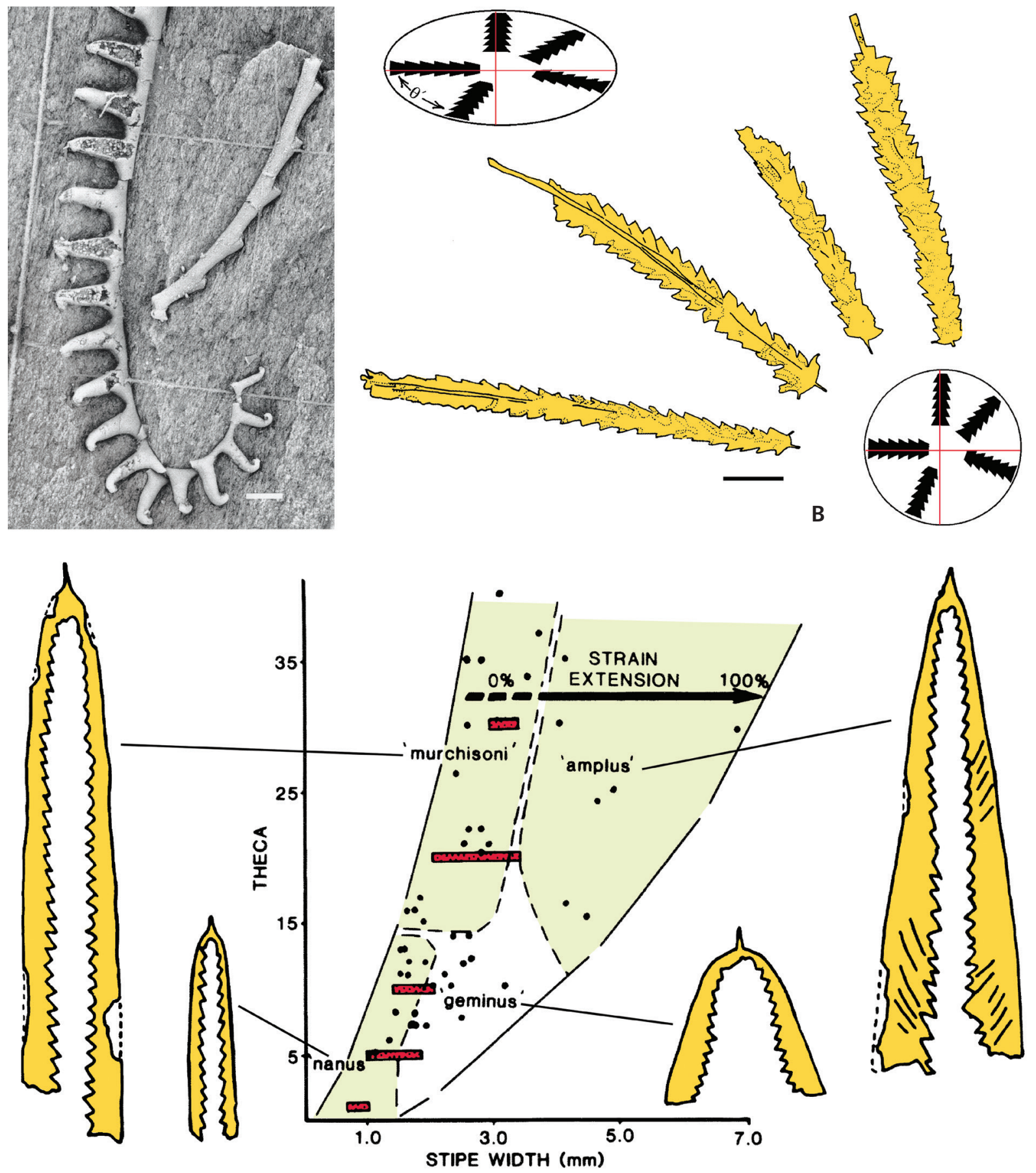

Figure 9. Deformation and strain. - A - Demirastrites triangulatus (Harkness, 1851), central Wales, showing deformation of a relief specimen, note thecal displacement in lowermost part of colony, Coronograptus gregarius (Lapworth, 1876), apparently undeformed specimen (after Palmer \& Rickards 1991, pl. 74). B - deformation of Levisograptus shelvensis (Bulman, 1963) in relation to direction of deformation (black line), after Jenkins (1980) and Goldstein et al. (1998). - C - Didymograptus murchisoni (Beck in Murchison 1839), interpretation of deformation at Abereiddi Bay, red boxes represent variation of undeformed types from Gelli Hill (after Jenkins 1987, fig. 4).

A specimen of Demirastrites triangulatus in full relief clearly shows the displacement of the individual thecae, while an associated fragment of Coronograptus gregarius appears to be undistorted (Fig. 9A). Deformation and pressure shadow mineralization may produce considerable problems for the identification of graptolites. Jenkins (1987) demonstrated deformation of flattened graptolites at Abereiddi Bay, where numerous specimens of pendent didymograptids may be explained as preservational morphs of a single species (Fig. 9C). Also the angle between 
a specimen and the direction of deformation may influence the identification considerably. Several specimens described by Bulman (1963) as separate axonophoran (biserial) graptolite species were interpreted by Jenkins (1980) as representing the same taxon (Fig. 9B).

\section{Weathering}

Surface weathering affects most of the fossils we collect (Fig. 10) and only material from drill cores or fresh material from active quarries may be unmodified by weathering. Thus, it is an important aspect we need to consider when we look at graptolites and try to identify their preservational conditions. The effects of weathering might be quite variable, as weathering can affect organisms in any stage of the fossilization process, in fresh material, compacted specimens, thermally altered material and tectonically distorted ones. However, the effects of weathering do not attract much attention during identification of the material. Dark shales and mudstones may weather to light coloured, often yellow to whitish sediments (e.g. Victoria, Australia; Yangtze Platform, China; North America; North Africa), where often the fossils remain visible as darker outlines of carbon or faint imprints when the organic material has decayed. Similarly preserved material also exists in other regions, for example in the Czech Republic (Štorch 1998, 2015; Štorch et al. 2016; Manda et al. 2019).

The typical Australian graptolite material from Victoria consists often largely of pressure shadow minerals (Fig. $10 \mathrm{G})$, but sometimes remains of the organic material are preserved, especially in less strongly weathered material. Light coloured halos around the darker fossils (Fig. 10H) in a dark mudstone can be found commonly indicating partial weathering and disappearance of organic material (see many examples in Rickards \& Chapman 1991). This preservation is commonly found in flattened material, but may be found also in relief specimens. In extreme cases, the weathering leaves only faint imprints in the weathered sediments without any hints of preserved organic material (Fig. 10I).
The originally often pyritic fill of relief specimens of graptolites may be modified into limonite or other minerals through weathering effects, but the full three-dimensional shapes may be preserved even when the organic material of the fusellum has disappeared (Fig. 10A, L). Through partial compaction others only retain some of the constructional details (Fig. 10B). Pyrite filled tubaria may weather due to the decay of the pyrite and yellow to red colours of resulting iron hydroxide minerals may appear (Fig. 10C). A special development of this preservation is the white and pink colour (Fig. 5I) of the tubarium fills of Lower Ordovician graptolites from Argentina (Toro \& Maletz 2008). Unfortunately, it was not possible due to the limited material to figure out the composition of this mineral fill. Pyrite fills of graptolites may be relatively stable and are unchanged even after decades in collections, but in other cases quickly decay through pyrite disease (Fig. 10D), a factor that is important for many fossil collections (Birker \& Kaylor 1986, Newman 1998) as it can destroy important fossils very quickly.

Weathering may enhance the visibility of flattened specimens due to the combined presence of dark iron hydroxide minerals from pyrite degradation and remains of organic material (Fig. 10E) and also the tectonic deformation of graptolites. In the case of low deformational values, little may be seen in the organic fabric, but stronger deformation forms more or less parallel fractures. These may be enhanced by the dyeing of the pressure shadow minerals through iron mineralization (Fig. 10G). In certain localities, more than one direction of deformation can be recognized through these fractures (Fig. 10J). Various staining of the preserved organic films or the preserved pressure shadow minerals may alter the original colour of the pressure shadow minerals often to yellowish or reddish colours (Fig. 10C, F, G). The lack of organic material in some specimens of Sphenoecium wheelerensis Maletz \& Steiner, 2015 (Fig. 11H) may also be due to weathering and subsequent mineralization of the fossil. The material shows imprints of fuselli, but the dark film suggestive of organic material was identified as $\mathrm{Fe}$ - and $\mathrm{Mg}$ - rich aluminosilicates (Maletz \& Steiner 2015, p. 1083).

Figure 10. Weathering of graptolites. • A - Sinograptus typicalis Mu, 1957, NIGP 8909, holotype, pyritic internal cast, China. $・$ B - Baltograptus geometricus (Törnquist, 1901), NIGP 31987, low relief cast with part of fusellum (dark), weathered pyrite fill red, China. • C - Normalograptus mohawkensis (Ruedemann, 1912), GSC 139252, Quebec, Canada, slightly weathered specimen, fusellum black, orange weathering of iron minerals. • D - Pseudorthograptus cyperoides (Törnquist, 1897), LO 1294T, syntype, Tommarp, Scania, Sweden, decayed pyritic internal cast. • E - Petalolithus folium (Hisinger, 1837), PS730, flattened, Tmaň, Czech Republic. • F - (?)Kiaerograptus supremus Lindholm, 1991, internal cast, see gaps indicating decay of organic material. $• \mathrm{G}$ - Arienigraptus angulatus (Mu, Geh \& Yin in Mu et al., 1962), SMF 75825, Victoria, Australia, strongly tectonized and weathered specimen, lineation shown by pressure shadow minerals dyed orange by iron oxides. $\bullet \mathrm{H}-$ Eotetragraptus arcuatus (Hall, 1865), NIGP 10643, China, flattened and weathered specimen, showing preservation of some organic material in black, note halo of weathering (illustrated in Mu et al. 1962, pl. 7, fig. 1). • I - Didymograptus artus (Elles \& Wood, 1901), TU Bergakademie Freiberg Nr. FG-667-1, Darriwilian, Jordan, imprint of flattened specimen in weathered, originally black shale. • J - Pseudisograptus manubriatus (Harris, 1933), NMVP 30513, Victoria, Australia, tectonized, showing greenish pressure shadow minerals and some preservation of fusellum (in black). $\mathrm{K}-$ Paradelograptus norvegicus (Monsen, 1937), AA-JTZ-OI-10, Fezouata, Morocco, flattened specimen, weathered. $\bullet$ L - Paratemnograptus magnificus (Pritchard, 1892), AA-BIZ13-OI-14, Fezouata, Morocco, internal cast, originally pyritic, no organic material preserved. Scale bar indicates $1 \mathrm{~mm}$ in each photo, except $\mathrm{J}$, where it is $10 \mathrm{~mm}$. 
Jörg Maletz • Hemichordata (Enteropneusta \& Pterobranchia, incl. Graptolithina)
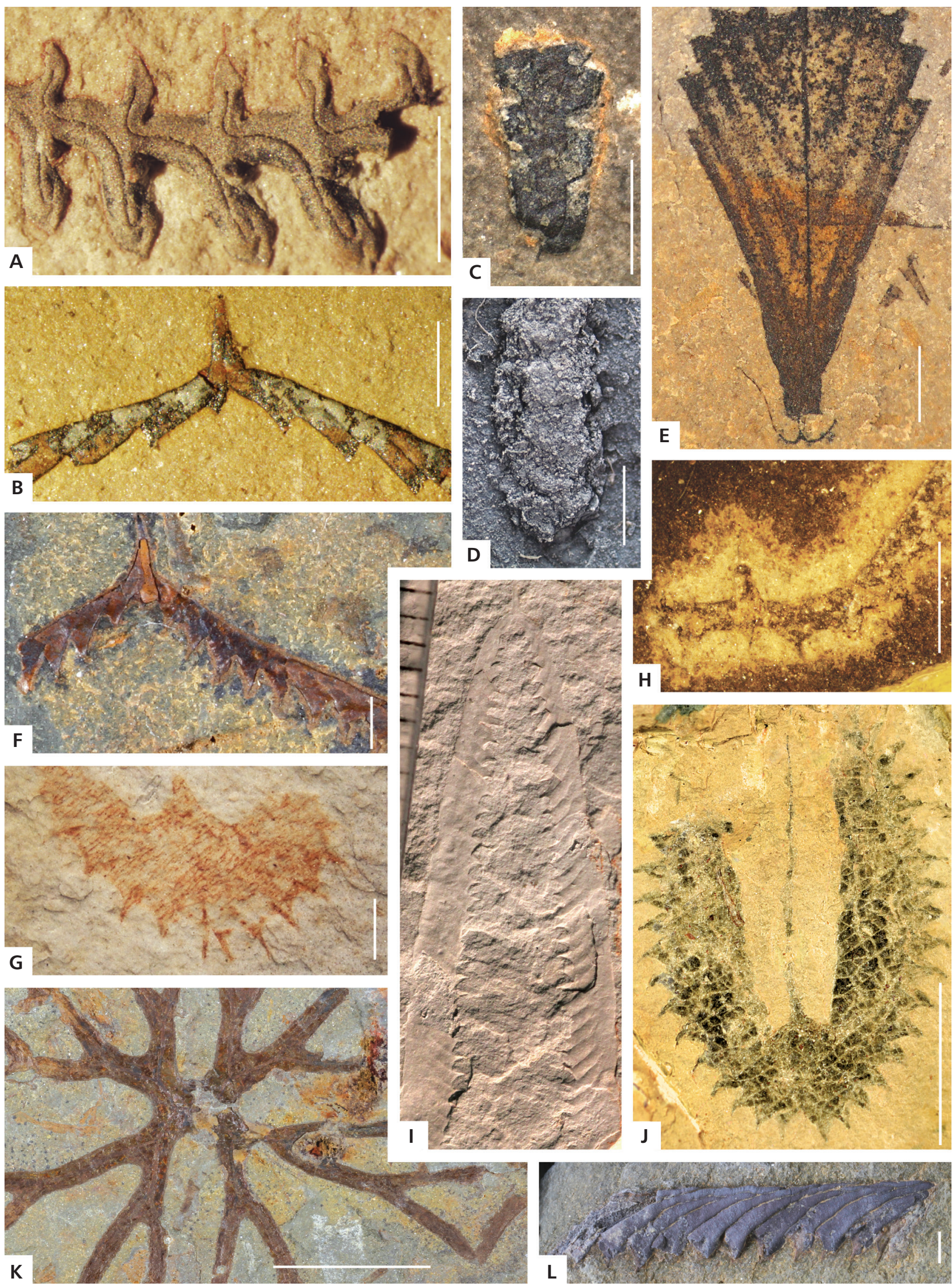


\section{Palaeozoic fossil Lagerstätten and graptolites}

Muscente et al. (2017) discussed the concept of Konservat-Lagerstätten and considered these to be geological deposits containing fossils with remains of non-biomineralized tissues (e.g. organic or carbonaceous material). The autors stated that 'hemichordates include clades with planktonic and cosmopolitan lifestyles that influence the preservation and geospatial distributions' as an argument to exclude them from their investigation of 'exceptionally preserved fossil assemblages', even though they illustrated the pterobranch Yuknessia (Sphenoecium wheelerensis in Maletz \& Steiner 2015) as an important example (Muscente et al. 2017, fig. 2i). Thus, graptolitic successions are not included, even though they represent a common occurrence of organically preserved fossils in the Palaeozoic and in many lagerstätten. They can provide essential information on preservational aspects of the fossils in these lagerstätten. While many graptolitic successions include a variety of other fossils (e.g. Hall 1865, Schauer 1971), these additional fossil groups are generally ignored and not described due to the special focus of the investigators. More and more lagerstätten have become known that include graptolites, however (e.g. Young et al. 2012, Baliński \& Sun 2015, Gutiérrez-Marco \& Martin 2016). The Burgess Shale itself is not an exception as the record of benthic graptolites in this lagerstätte indicates (e.g. Walcott 1919, Ruedemann 1931, Ramírez Guerrero 2019). Thus, a few examples are provided here showing the general preservation of this material and the consistent interpretation possible.

\section{Burgess Shale (Cambrian)}

The Burgess Shale (overviews in Gould 1989, Briggs et al. 1994) is one of the most treasured fossil lagerstätten in the world and the mechanism of the preservation of its fossils is still debated (cf. Powell 2003; Gaines et al. 2012a, b; Wilson \& Butterfield 2014). The Burgess Shale is regarded as the standard for the Burgess Shaletype preservation (BST) of many authors (e.g. Butterfield 1995, 2003; MacGabhan 2014; Gaines et al. 2012b). It has been seen as a special and unique (exceptional) type of preservation restricted to the lower and middle Cambrian (Zhang et al. 2008, Parry et al. 2017, Van Roy et al. 2015). Briggs \& Kear (1993) and Butterfield (2003) discussed the organic remains of Burgess Shale fossils and postulated a rapid degradation and collapse of cellular tissue, leaving a residue of resistant recalcitrant extracellular structures, largely the preservation of cuticular material. Thus, these authors were aware of the differences of the various organic materials to be preserved in the fossil record.
Sedimentology, diagenesis, metamorphism and tectonics have been incorporated in the interpretation of this 'preservational window' ( $c f$. Butterfield et al. 2007, Gaines et al. 2008, Gaines 2014), but may play a larger role in its fossil preservation and interpretation than anticipated. A geological interpretation (cf. Powell 2003, Powell et al. 2003, Collom et al. 2009, and others) may provide a more differentiated insight into the fossilization processes and resulting modifications of the Burgess Shale and provide a better understanding of its fauna.

As graptolite tubaria are preserved as carbonaceous films, they should be understood in terms of Burgess Shale-type preservation. A number of Burgess Shale fossils may be identified as graptolites, even though this identity is not proven in all cases (Maletz 2019a, Ramírez Guerrero 2019). The Burgess Shale fossil Dalyia Walcott, 1919 was identified as a possible graptolithine by Maletz \& Beli (2018), but the inclusion is problematic due to the unusual construction of the specimens. Ruedemann (1931) described the encrusting graptolite Chaunograptus scandens associated with a specimen of the sponge Tuponia lineata Walcott, 1920 from the Burgess Shale. Maletz \& Steiner (2015) and Maletz \& Cameron (2016) identified the problematic Burgess Shale genus Yuknessia Walcott, 1919 (Fig. 11F) as a possible pterobranch. LoDuca et al. (2015) documented the presence of fuselli in Yuknessia material from the Burgess Shale (the specimen is identified as Sphenoecium by Maletz \& Steiner 2015).

Erect growing, bushy benthic graptolites are present in another Burgess Shale-type deposit not far from the original site (Johnston et al. 2009a, b). The material includes large specimens of a dithecodendrid graptolite, identified as Graptolithina gen. et sp. nov. The fusellar construction can be seen from imprints in the sediment, but the original organic material of the graptolites is not preserved.

\section{Chengjiang (Cambrian)}

The Chengjiang fauna of China ( $c f$. Zhang \& Hou 1985; Hou et al. 1991, 2004), a lower Cambrian fossil assemblage of originally organically preserved and mineralized organisms appears to be deeply weathered, but still contains some amounts of preserved organic material (see Forchielli et al. 2012, 2014). The fossils are strongly affected by sub-recent to recent weathering and oxidation of organic material and diagenetic clay mineral formation (Fig. 11A). Phosphatization and pyritization played a key role in the preservation of the fossils. Interestingly, Forchielli et al. $(2012,2014)$ show that iron mineral precipitation is confined to later diagenetic processes and is not crucial for the preservation of volatile tissues. Fossils in grey shales, interpreted as least altered, lack evidence of pyrite or any other iron minerals replacing tissues. The 

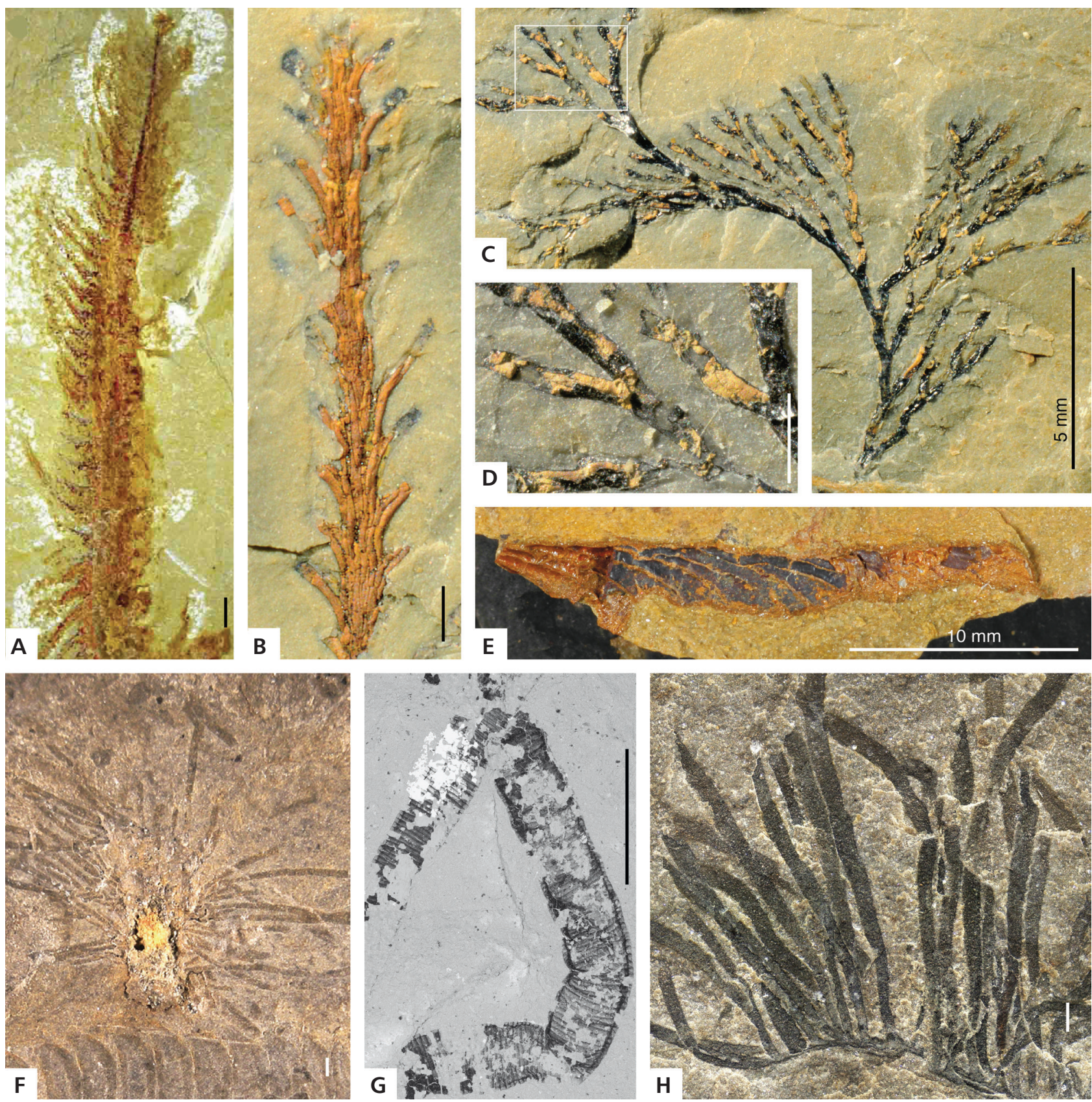

Figure 11. Graptolites and Palaeozoic Lagerstätten. - A - Galeaplumosus abilus Hou et al., 2011, holotype, flattened, no preservation of organic material, Chengjiang, China, now identified as part of Xianguangia sinica Chen \& Erdtmann, 1991 (Hou et al. 2011, fig. 1e). • B - ?Acanthograptus sinicus Hsü \& Ma, 1948, limonitic fill, weathered from pyrite, Fenxiang Biota, China (Maletz \& Kozłowska, 2013, fig. 1). • C, D - (?)Aspidograptus uniflexilis Yu et al., 1985, limonitic fill with fusellum in black, Fenxiang Biota, China (Maletz \& Kozłowska, 2013, fig. 4). E - Paratemnograptus magnificus (Pritchard, 1892), weathered pyrite fill surrounded by iron oxides, Fezouata, Morocco. • F - Yuknesia simplex Walcott, 1919, USNM 35406, holotype, notice pyrite concretion in center, imprint, no organic material preserved, Burgess Shale, Canada. $\bullet \mathrm{G}-$ Spenoecium wheelerensis Maletz \& Steiner, 2015, holotype, part, SEM-BSE photo to show fusellar construction, House Range, Utah, white colour indicates pyrite (see Maletz \& Steiner 2015, fig. 17b). $・ H$ - Spenoecium wheelerensis Maletz \& Steiner, 2015, specimen showing dark mineralization, organic material of fusellum is not preserved, House Range, Utah (Maletz \& Steiner 2015, fig. 7a). Scale bar is $1 \mathrm{~mm}$ unless stated otherwise.

late stage chemical alteration and weathering was linked to intense post-Cretaceous faulting.

The preservation of the Chengjiang fauna (e.g. Gabbott et al. 2008) represents a situation similar to the Bur- gess Shale fauna. The succession is less strongly metamorphosed and apparently not tectonized. Hemichordates (pterobranchs) have been claimed to exist at Chengjiang, but $\mathrm{Ou}$ et al. (2017) identified the supposed hemichordate 
Galeaplumosus abilus Hou et al., 2011 as an isolated tentacle of the possible cnidarian Xianguangia sinica Chen \& Erdtmann, 1991 (Fig. 11A). The precise mode of preservation of this material has not been determined, unfortunately. Pterobranch remains have been discovered in the slightly older Kaili Biota (Harvey et al. 2012) and in the lower Cambrian of Greenland (Slater et al. 2017), showing indications of fusellar construction, preserved as chemically isolated small pieces of organic material. Maletz (2014b, 2019a), Maletz \& Steiner (2015) and Maletz \& Beli (2018) demonstrated that pterobranch remains are found in the early Cambrian and predate the Chengjiang Biota, and thus, could be present in the Chengjiang fauna.

\section{Fenxiang (Ordovician, Tremadoc)}

Baliński \& Sun (2015) described the early Ordovician shallow-water Fenxiang Biota of China as an Ordovician Burgess Shale-type fauna. While mixing this term with a Burgess Shale-type preservation, the authors stressed the much wider temporal distribution of this type of preservation in the Ordovician. Baliński \& Sun (2015) illustrated a range of organisms. The supposed soft parts are often preserved as weathered, pyritized remains of the organisms in three dimensions (Baliński et al. 2014), but the original composition of the material is unclear. Others are phosphatized like the antipatharian coral remains (Baliński et al. 2012, Baliński \& Sun 2017) and phosphatic brachiopods in which the long pedicle is preserved in three dimensions in pyrite, now weathered to limonite (Baliński \& Sun 2013). Maletz \& Kozłowska (2013) described a small fauna of dendroid graptolites from the Fenxiang Biota, including Acanthograptus, Aspidograptus, Dendrograptus and Koremagraptus (Fig. 11B-D). The material is preserved in partial relief, probably pyrite filled originally, and shows some organically preserved fusellum, but also shows extensive weathering and limonitization of the fills. In many relief specimens the internal limonitic casts may be exposed through the splitting of the shale (Fig. 11B, D), separating the covering by the fusellum on the counterpart slabs. There is no information available on the thermal history and tectonic distortion of the succession, but the preservation of the graptolites as dark to black, often massive looking fusellum may indicate a low grade of metamorphism at maximum. There is no evidence in the specimens for a tectonic overprint.

\section{Fezouata (Ordovician, Tremadoc)}

The Fezouata Biota (Van Roy et al. 2010, 2015) were characterized as typical of Burgess Shale-type assemblages.
Van Roy et al. (2010) compared the preservation to the Chengjiang fauna of China. Graptolites are prominent in this early Ordovician fauna from Morocco and have been used to precisely date the succession (Gutiérrez-Marco \& Martin 2016). Therefore the Fezouata Biota are discussed in more detail here. Saleh et al. (2020a) discussed the preservation of the Fezouata fossils and stated that 'entirely soft non-cuticularized organisms are absent', but suggested that 'partly mineralized and sclerotized tissues' may have protected the soft tissues. Saleh et al. (2020b) demonstrated that the soft-tissues described from echinoderms are the results of recent weathering and fossil preparation, probably also negating the claim of the presence of soft tissue preservation in the specimens of Lefebvre et al. (2019). Based on these interpretations, it appears that there is no real soft tissue preservation or preservation of carbonaceous material in the Fezouata Biota, which is supported by the graptolite fauna.

The graptolite fauna includes largely flattened specimens from the Tremadocian and lower Floian (Lower Ordovician). More rarely, fragments are preserved in partial to full relief as internal casts. Van Roy et al. (2010, suppl. info fig. s2i) even mentioned preserved zooids in a tuboid graptolite, but these were never described. Illustrations of the graptolite faunas from the Fezouata Lagerstätte (Martin et al. 2016) show that the specimens are actually poorly preserved and largely do not retain any organic material. The preservation, often as reddish outlines implying lack of organic material, may indicate late stage weathering impregnation with iron minerals. Some specimens are preserved in relief as originally pyritic internal casts (Fig. 11E), but are clearly modified by subsequent mineralization and weathering. However, there is much more to the geological history of the material that has not been considered so far in connection with the fossil record, but can easily be understood from a closer look at the regional geology.

The Fezouata lagerstätte of the Anti-Atlas is found in a mountain chain showing considerable tectonic deformation (Caritg et al. 2004, Helg et al. 2004, Burkhard et al. 2006, Robert-Charrue \& Burkhard 2008, Ruiz et al. 2008). Apart from gentle folding, probably already starting in the late Carboniferous, considerable thermal influence can be seen in the strata. Soulaimani et al. (1997) discussed the deformation and thus formed schistosity of Cambrian to Silurian rocks of the Anti-Atlas and noted the presence of chloritic mineralizations. Ruiz et al. (2008) used the illite crystallinity to determine the palaeo-thermal gradient and recognized a considerable burial metamorphism. While the boundary between epizone and anchizone metamorphism (at $c a .300^{\circ} \mathrm{C}$ ) was found approximately at the Cambrian-Ordovician boundary in the western Anti-Atlas, it is found in the middle-upper Cambrian in the central AntiAtlas. The diagenesis/anchizone boundary $\left(\mathrm{ca} .200{ }^{\circ} \mathrm{C}\right)$ 
would be found probably in the Silurian, while the Devonian strata are clearly in the diagenetic zone (see Ruiz et al. 2008, fig. 4). The final exhumation of the Anti-Atlas happened in the Mesozoic-Cenozoic (Ruiz et al. 2011, Oukassou et al. 2012) as zircon and apatite fission-track data and thermochronological analysis suggest. These data indicate that the early Ordovician graptolites and accompanying fossils are considerably thermally altered and tectonized. Due to surficial weathering, the material is also poorly preserved, altered and dyed through iron minerals, enhancing the contrast between the specimens and the surrounding sediment. This may have led to the reddish colour many graptolites (and also other fossils) show (see Van Roy et al. 2010, Martin et al. 2016). Specimens preserved originally as pyritic internal casts would have to be converted into limonite or other iron minerals due to the weathering. Tectonic deformation of the Fezouata fossils has not been documented so far, but may be difficult to recognize in the material, even though it has to be expected from the tectonic history of the region. Conodont faunas from the Fezouata Biota are too poorly preserved to gain insight into the thermal history of the material, as the specimens are largely recrystallized to fluorite due to the extraction method used (Lehnert et al. 2016).

Lower Ordovician faunas from a number of drill cores in the Algerian Sahara, outside the Anti-Atlas (e.g. Legrand 1964a, b; 1974) show much better preservation of graptolite fusellum in chemically isolatable material. Legrand (1974) for the first time demonstrated the quadriserial development of the proximal end in Rhabdinopora flabelliformis ssp. from this material. The preservation is restricted to the tubaria showing all details of the fusellar construction. It does not include remains of the stolon system and remains of the zooids have not been discovered. This material did not experience higher metamorphic coalification or tectonic deformation, even though some fractures are visible in the material. This fracturing, however, may be due to the method of preparation.

\section{Eramosa (Silurian, Wenlock)}

The Eramosa Lagerstätte (Tetreault 2001) is one of the Silurian lagerstätten on the Bruce Peninsula of Ontario, Canada. According to von Bitter et al. (2007), the Eramosa Lagerstätte is restricted to only four localities, producing three different biotas. LoDuca \& Tetreault (2017) termed it an 'algal-Lagerstätte' due to the domination of algae in the fossil composition. The fossils are found in the Eramosa Formation (Brett et al. 1995, Brunton 2009) of Sheinwoodian, Wenlock age (Bancroft et al. 2016), preserved as calcium phosphate and as carbon films.

The Eramosa Formation is widely distributed in the region as part of the Lockport Group. The Lockport Group includes several formations and the correlation is often difficult, especially with old fossil records as various informal names are used in the region and fossil faunas are not too well located (see Brett et al. 1995). Organic preservation of fossil faunas has previously been described from the Lockport Group of western New York and southern Ontario. Dendroid graptolites are common in the so-called 'Gasport Lens' of the Lockport limestone (e.g. Ruedemann 1925, 1947, p. 127) and in the Lockport Dolomite at Hamilton, Ontario (Spencer 1884b, Bassler 1909), also including taxa now referred to as dasycladacean algae (LoDuca 1990). It is to be expected that this type of preservation is distributed much more widely in the region, but has not been investigated in detail. Comparable graptolite faunas from the Rochester Shale of the Clinton Group (see Brett et al. 1995 for lithostratigraphy) are preserved as thick, black organic films of flattened tubaria, sometimes even showing partial relief, as in the type material of Dictyonema retiforme (Hall, 1843) redescribed by Maletz (2019b).

LoDuca \& Brett (1991) discussed the Medusaegraptus epibole from the Niagara Falls Member of the Goat Island Formation, described first by Ruedemann (1925), as an exceptional biota with non-calcified organisms such as marine algae, annelids, and possible land plants. The fossils include a diverse fauna of dendroid graptolites that in part may have been found in life position as the completeness of the material indicates ( $c f$. large specimen of Dictyonema crassibasale: Ruedemann 1925, pl. 1). Also the specimens of the noncalcified dasycladacean alga Medusaegraptus mirabilis (Fig. 12A) are considered to be preserved in situ in the sediment in a normal marine environment (LoDuca 1990). The preservation of the Medusaegraptus epibole is closely comparable with that of the Eramosa Formation in the same region.

Dendroid graptolites from an equivalent of the Lockport Group of New York State and Ontario can also be found in inter-reef facies of Huntington, Indiana (Erdtmann \& Przebindowski 1974, Erdtmann 1976) and a number of further localities referred to as KonservatLagerstätten (Kluessendorf 1994). The material of the Mississinewa Shale was originally described by Shrock (1928). Erdtmann \& Przebindowski (1974) described and illustrated the fossils and remarked on the preservation of organic material in many specimens found in life position preserved in situ in the shale. Apart from a number of dendroid and graptoloid graptolites, remains of echinoderms, worms and other undetermined fossils were found, but never described in detail.

Little is known about the preservation of the fossils in the Eramosa Lagerstätte and related strata, even though preservation as carbonaceous films is generally understood for the pterobranch and algal material in the region. Collette \& Rudkin (2010) described phyllocarids 
from the Eramosa Formation in some detail, but did not provide detailed information on the preservation of the material, which is apparently preserved as low relief molds of the specimens not bearing any organic material. Waddington et al. (2015) discussed marine scorpions and showed them to be preserved either as low imprints or films of dark material (not necessarily organic). There is no information on the CAI of the conodont faunas available for the discussed sections. Thus, information on the thermal history of the faunas is not available. The Eramosa Formation and related units may represent the typical preservation of the shallow water marine biota in the region including numerous organically preserved taxa.

\section{Mazon Creek (Carboniferous)}

The Mazon Creek fauna does not include any graptolites or pterobranchs, but two species of enteropneusts have been described (Cameron 2016). Apart from the longknown Mazoglossus ramsdelli Bardack, 1997 (Maletz 2014b), Saccoglossus testa Cameron, 2016 was referred to the extant genus Saccoglossus and represents the second oldest enteropneust known from the fossil record. Even though the preservation of the Mazon Creek fossils is often considered to be good, the completely preserved outlines of the enteropneust specimens do not show the preservation of any organic material (Fig. 12B). They are found as light colour stains contrasting with the slightly darker matrix of the siderite concretions, probably the result of oxidation of pyritic replacements or weathering of the organic components of the original specimens (Murdock et al. 2016), lacking anatomical details. Baird et al. (1986) discussed the taphonomy of the lagerstätte and considered rapid burial prior to significant decomposition and subsequent concretion formation as the main reason for the preservation of these molds and impression fossils. The whitish mineralization is considered as a secondary calcite precipitation on the fossils by Baird et al. (1986), but was identified as caolinite by Murdock et al. (2016) (see Fig. 12B). It is unclear, whether organic material is preserved in most specimens. Nitecki \& Schramm (1976) described the problematicum Etacystis communis as a possibly colonial organism in which the individuals are connected with a stolon system and compared it with the pterobranch hemichordates.

\section{Graptolites and the understanding of organically preserved fossils}

As palaeontologists, we often pick the best and ignore the poor in our fossil hunting. The identification of tapho- nomic windows and the supposed special or exceptional preservations in certain deposits (e.g. Orr et al. 2003, Porter 2004, Zhao et al. 2005, Cherns et al. 2008, LaFlamme et al. 2014, Baliński \& Sun 2015, Bienkowska-Wasiluk et al. 2015, Tarhan et al. 2016, Cunningham et al. 2017, Eldijk et al. 2018) has sometimes been considered as more important than a holistic approach comparing the preservation of the various tissues and materials in fossils and understanding their preservational potential in connection to other geological factors (Purnell et al. 2018).

In understanding the preservational aspects of fossil pterobranchs, it has to be recognized that the preservation of organic material per se cannot be regarded as exceptional preservation. What appears to be exceptional in many Konservat-Lagerstätten is the presence of complete cuticularized animals (e.g. arthropods in the Burgess Shale and Chengjiang Biota), which are usually preserved as fragments and moulting remains in other sediments. The actual composition of the preservable or preserved material of a fossil has to be analyzed to evaluate the preservational potential of certain lagerstätten. While we are excited about the presence of fossils, it is often unclear how they are actually formed. Thus, we miss to investigate and analyse the chemical (biogeochemical) composition of the remains in order to recognize features that are unlikely to be preserved.

\section{Biomineralized and organically preserved fossils}

In terms of body fossils, we have to consider the main preservable aspects, the biomineralized skeletons and shells and other, organic material, be it skeletons or tissues. The original composition of an organism may lead to certain parts being preserved more readily, whereas other portions will decay within a short time, as we have seen in the examples of the Hemichordata. So we find the bones of vertebrate skeletons (biomineralized), but rarely, as in the feathered dinosaurs and early birds of the Jehol Biota (e.g. Hou et al. 1995, Ji \& Ji 1996), we have remains of their organic bodies (cellular tissues) or coverings of their skin, feathers or hair (extracellular or recalcitrant material) formed under special preservational conditions. Thus, the situation is closely comparable to that of the preservation in the Hemichordata discussed earlier. Yang et al. (2020) discussed the preservation of some of the supposedly earliest biomineralizing metazoan, the cloudinids, as originally organic, formed from chitinous or collagenous material, showing the interdependence of preservational aspects.

The preservation of the soft tissues or cellular tissues, sometimes also called labile tissues, might be extremely difficult in the fossil record (Butterfield 1990, Briggs \& Kear 1993) and in invertebrate fossils is based largely on 

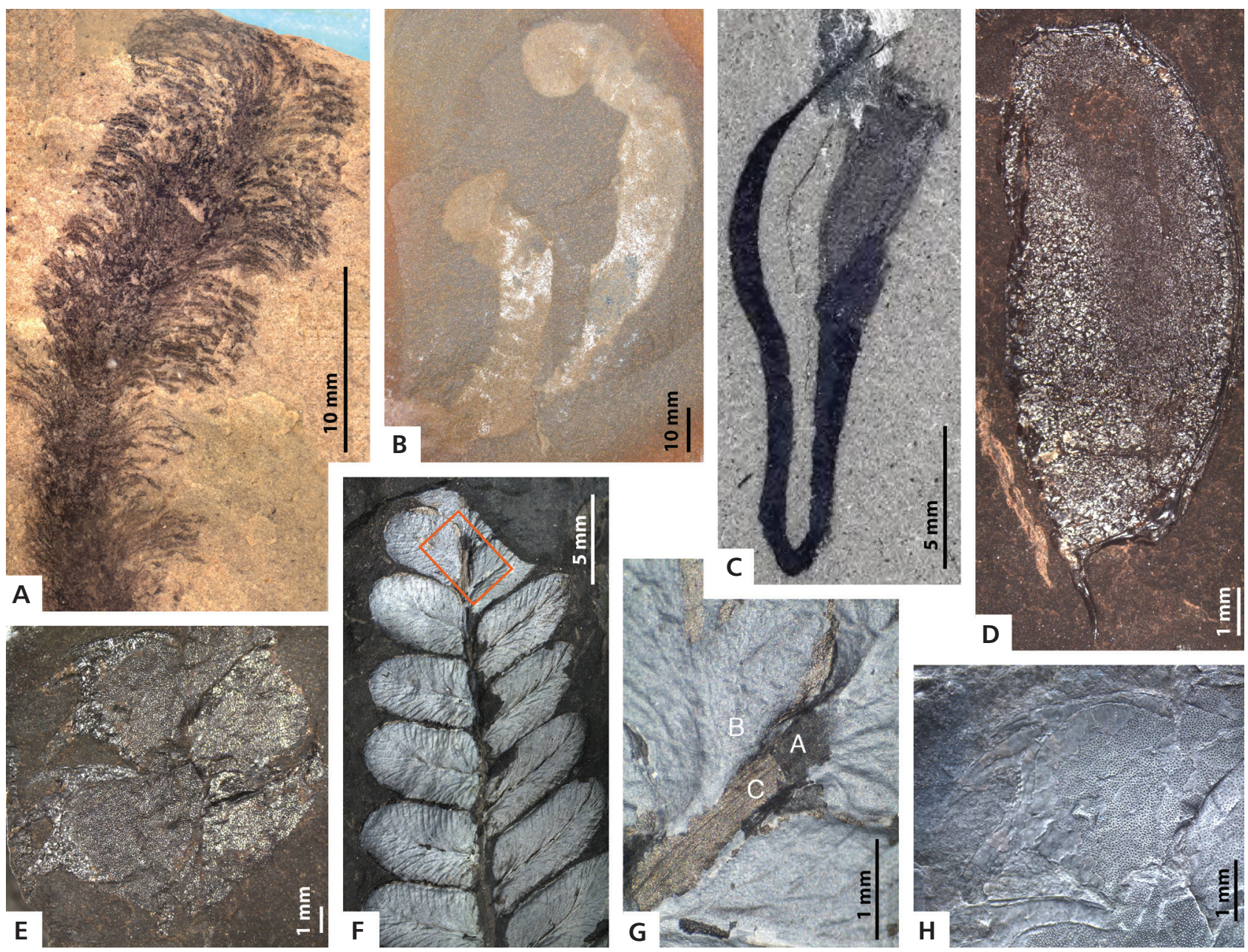

Figure 12. Organic preservation in fossils. A - Medusaegraptus mirabilis Ruedemann, 1925, SMF 75806, showing organic preservation, Lockport Formation, Ontario, Canada. • B - Mazoglossus ramsdelli Bardack, 1997, FMNH 45207, holotype. Francis Creek Shale, Illinois, Will, Kanakee or Grundy County, Mazon Creek Region. • C - Spartobranchus tenuis (Walcott, 1911), USNM 108494, lectotype, polarized light, Burgess Shale, Canada. • D -phyllocarid carapace, GSC 140106, late Tremadoc, Cow Head Group, Martin Point, western Newfoundland, Canada. • E, H -undetermined arthropod fragment, GSC 140107, late Tremadoc, Cow Head Group, Martin Point, western Newfoundland, Canada; H - detail showing surface ornamentation, specimen coated with ammonium chlorite. $\bullet$ F, G - Neuropteris attenuata, SM.B.22105, specimen coated with white pressure shadow minerals (B), some pyrite (C) and organic material (A) is visible, Piesberg near Osnabrück, Germany, Carboniferous.

interpretation of the outlines of the specimens. Typical examples are the enteropneust worms described from the Burgess Shale (Caron et al. 2013, Cameron 2016, Nanglu et al. 2016). Most preserved materials in the Burgess Shale (cf. Gould 1989, Briggs et al. 1994) may, however, be regarded as remains of cuticles, either of worms or of arthropods and has to be identified as recalcitrant material. Even in the Burgess Shale, the preservation of soft tissues or cellular tissues is rare in most taxa, but may be found in ctenophores or in some completely preserved sponges (Botting 2012). The preservation of organ systems and neurological tissues in Chengjiang fossils has recently been challenged and explained as possible microbial biofilm remains following the decomposition of the original tissues (Liu et al. 2018). Thus, in many cases of supposed soft body preservation, actually the preservation only includes recalcitrant tissues, and true cellular tissues such as organs, skin or muscles are not preserved at all, as Steiner (2018) suggested.

All extracellular materials are here identified as recalcitrant materials, formed as secretions from special glands of the organisms. The cuticle is a tough, recalcitrant material covering the outside of many organisms (Fig. 12E, H), animals and plants (Fig. 12F, G: Neuropteris attenuata, Carboniferous), which prevents loss of fluids and provides protection. It may be variable in thickness, thus also variable in its preservational potential and can break into smaller pieces due to robustness of involved material and the differentiation or segmentation of the involved organisms (e.g. Wilson \& Butterfield 2014). 
Briggs \& Kear (1993) described the decay of the extant polychaete Nereis in some detail. They recognized that all muscles were broken down after eight days, while the recalcitrant cuticle lasted much longer. Only the most durable parts, the jaws and setae were retained much longer. Sansom (2016, fig. 2) provided information on the extant priapulid Priapulus, in which basically all noncuticular tissue was lost after six days. Cuticular tissue was still present after 224 days.

Arthropod cuticules, especially of phyllocarids (Fig. 12D), are often found associated with graptolites in Palaeozoic shales, and their remains behave similarly during fossilization (Gupta \& Briggs 2011, HartkopfFröder et al. 2015). They are part of what is now identified as 'small carbonaceous fossils' or SCF's (Butterfield \& Harvey 2012) but are very difficult to relate to a specific organism. Arthropod cuticles are quite common in the fossil record and it is known from extant taxa, that the foregut and the hindgut are also outlined by a cuticular development, and thus may be responsible for the interpretation of intestinal remains (Chapman 1985, Steiner 2018). The cuticle may be thin and difficult to preserve (caryocaridids: Vannier et al. 2003), but certain parts like the feeding apparatus of arrow worms are heavily cuticularized and easily preservable (e.g. Vannier et al. 2007). A similar situation can be seen in the scolecodonts where only the jaw apparatuses are preserved, while we know little about the rest of the organisms from the fossil record (e.g. Kielan-Jaworowska 1966; Eriksson et al. 2004, 2017). The development of the black stolon system of the Pterobranchia (Schepotieff 1906, Maletz \& Cameron 2016) may be more easily related to a cuticular development as it represents the hardened surface of the gymnocaulus, connecting the individual zooids of the graptolite colony. Both, the graptolite tubaria and the stolon system, are durable organic materials and especially the tubaria are common in the fossil record. Therefore, they can be investigated in some detail and represent a key to understand the preservation and modifications of organic materials in geological history.

\section{What is exceptional preservation?}

In general, exceptional preservation appears to describe the preservation of more or less complete fossil specimens and not as fragmented remains, largely as organic films (e.g. Burgess Shale, Chengjiang Biota, etc.). The preservation as organic material, however, may lead to a more precise question: Does exceptional preservation of fossils also invariably means carbonaceous preservation and how can we interpret this? Certainly, it is exceptional when we find fossil organisms that show the preservation of features we consider to be non-preservable (e.g. preservation of cellular material), but there may be a better interpretation when we understand the differences between materials, sediments, diagenesis and tectonics; when we understand all the things that can happen to a dead organism during the process of taphonomy, and the preservation of graptolite remains may provide a usefull key to our understanding of organically preserved fossils. Features may have a different explanation ( $c f$. Liu et al. 2018) and what we see may not be exceptional preservation, but represent different and sometimes exceptional circumstances under which certain materials are preserved, modified or replaced.

The preservation of complete carbonaceous carapaces of arthropods, as in the Burgess Shale or the Herefordshire lagerstätten for example, is as spectacular and special, as it is rare, as is the preservation of complete vertebrate skeletons. Altogether excellent preservation of fossils is rare and what we now often call Konservat-Lagerstätten (cf. Seilacher 1970) may include complete carapaces of animals - at least their outlines - the interpretation is only due our lack of understanding of the real preservational conditions. Even in these Konservat-Lagerstätten, the preservation of soft tissues or cellular tissues is extremely rare. The lax use of the term soft-bodied preservation may mislead us, so we do not look in enough detail at the preservational aspects. Recalcitrant material may be far more common and already provides us with a lot of otherwise unavailable anatomical information, but should not invariably be called exceptional.

(?)Kiaerograptus supremus Lindholm, 1991 (Fig. 13) is a common and widely distributed late Tremadocian graptolite species and a good example to compare various preservational aspects of a single taxon to understand the challenges to interpret and recognize an organically preserved fossil. The holotype of this species is preserved in full relief in a black shale in a drill core from southern Sweden (Fig. 13A, B). Many details of the tubarium are only visible when coated with ammonium chlorite (Fig. $13 \mathrm{~B})$, but information on the fusellar construction is not available at all. The specimen shows no tectonic distortion and little maturation of the well-preserved fusellum. A low relief specimen from Fezouata (Fig. 13C-E) is preserved as an internal cast, now probably made from limonite, but originally supposedly formed as a pyritic internal cast. It shows parts of the proximal development in obverse view including the presence of a sicular bitheca (Fig. 13E, arrow). Distally, the thecae are less well preserved and in the distal end, the cast is lost (Fig. 13D, red arrow). There is no preservation of organic material as the fine gap between the cast and the surrounding sediment shows (Fig. 13E: red arrows). This loss may have happened during the weathering of the sediment, shown through the red color of the iron staining. The preservation of this material is quite poor, as is the flattened and metamorphosed or coalified material from the Fågelsång 3 drill core of southern Swe- 

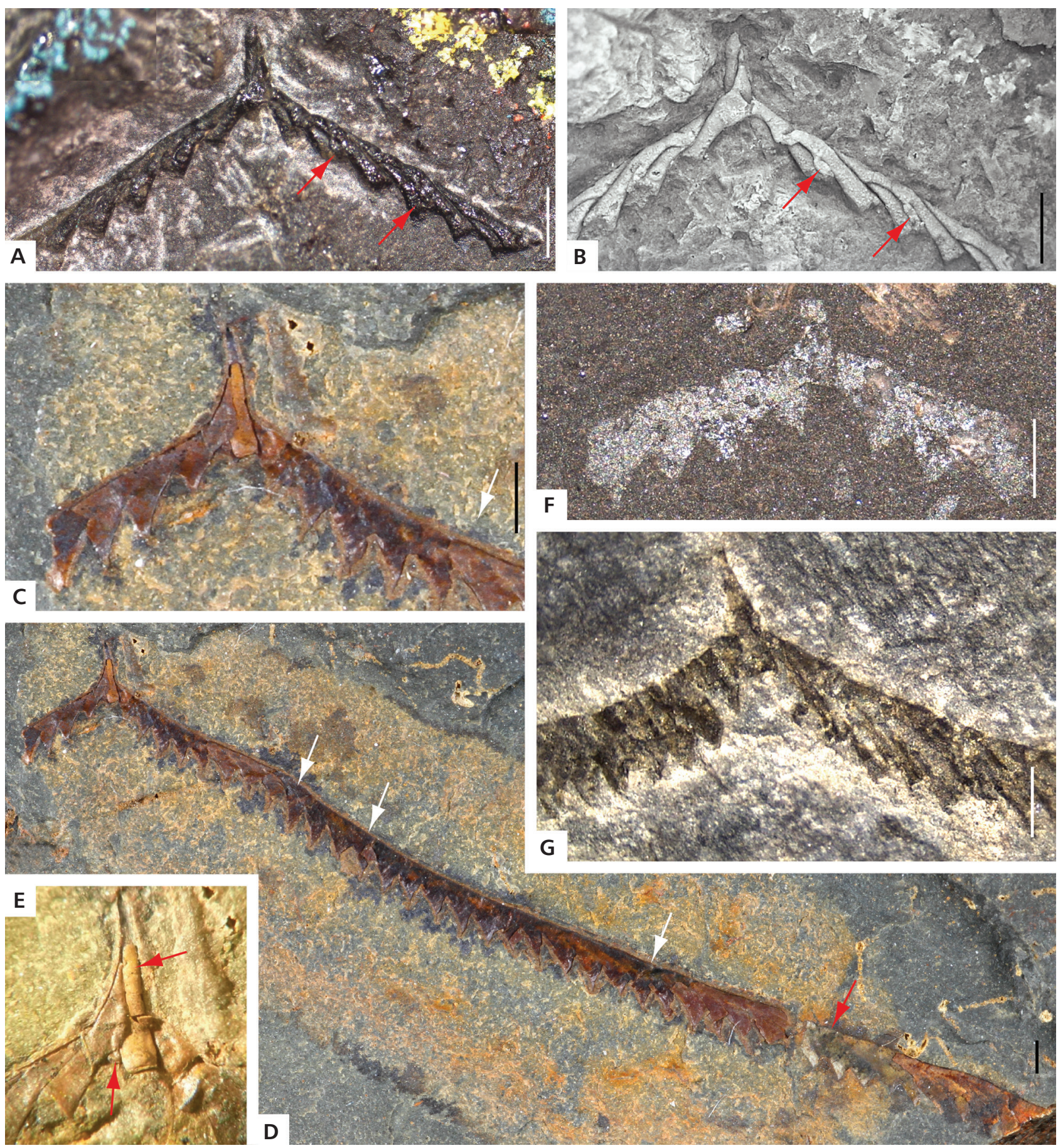

Figure 13. (?)Kiaerograptus supremus Lindholm, 1991 in various preservational aspects; A - LO 5970T, holotype, relief in black shale, Krapperup drill core at 151.46-151.50 m depth; B - LO 5970T, coated with ammonium chlorite to show details of tubarium construction; C -E - AA-BGF2-OI-6, specimen preserved in partial relief as an internal cast, Fezouata, Morocco (see Martin et al. 2016, fig. 5); F - PMU 31719/3, flattened, poor specimen, highly coalified, Fågelsång 3 drill core, 64.7-64.75 m, Scania, Sweden; G - SMF-BO CUL 8-042, Culpina, Bolivia, strongly tectonized and weathered specimen preserved as dark green pressure shadow minerals, no organic material preserved. Red arrows in A, B indicate bithecae. Scale bars indicate $1 \mathrm{~mm}$ in each photo.

den, showing a silvery shine (Fig. 13F). Specimens from the early Ordovician of Culpina, Bolivia are preserved as greenish pressure shadow minerals lacking the organic material of the original specimens (Fig. 13G). This material is strongly tectonized, as the asymmetrical outlines and the tectonic lineation of the rock indicate and show the effects of recent weathering. The comparison of the various specimens of (?)Kiaerograptus supremus shows the 
importance of understanding of late stage taphonomical changes for the proper identification of taxa and also to estimate the quality of preservation.

We need to investigate fossils in a geological context by using our knowledge on preservation and modification through geological history and not describing fossil preservation in narrow limits as exceptional. Thus, the change of the organic material through geological processes as documented here for graptolite faunas (Fig. 13) may help also to understand other 'exceptional' preservations. There are certainly differences between the organic material of the graptolite tubaria and the cuticles of arthropods or plants or even the microfossils like acritarchs and chitinozoans. However, many similarities also exist and show patterns in the taphonomy of organically preserved fossils that can easily be compared.

\section{Conclusions}

(1) The Pterobranchia can be regarded to provide typical examples of organic preservation in the fossil record and used as a guide to interpret the taphonomy of organically preserved fossils.

(2) Taphonomy includes all modifications of an organism from death to the discovery as a fossil.

(3) Organic preservation of fossils is in general nothing special, but may be found everywhere in suitable sediments and can only be regarded as an alternative to the preservation of biomineralized fossils.

(4) Thermal maturity investigations show that the geological modifications of the organic materials of fossils follow similar paths in the various groups of organisms, including both, animals and plants.

(5) Two types of organic material of fossils can be differentiated, cellular or soft tissues and non-cellular or recalcitrant materials (not tissues). These two types need to be differentiated carefully, as their preservational potential differs considerably.

(6) Metamorphism and tectonics change the fossil appearance considerably through coalification (heating) and the formation of pressure shadow minerals (tectonic deformation).

(7) Many 'exceptional' faunas actually represent poorly preserved fossils (e.g. Burgess, Chengjiang, Fezouata) in which the fossil recognition is enhanced by later taphonomic processes (diagenesis, metamorphism, tectonics, weathering).

\section{Acknowedgements}

This work was supported by grantDFGMA1269/7-1 of the German Science Foundation (DFG). Many people provided information and specimens for this investigation, especially Michael Steiner (FU Berlin, Germany), with whom I talked frequently about the topic. Juan-Carlos Gutiérrez-Marco (Madrid, Spain) provided photos of Fezouata specimens. Charles E. Mitchell (SUNY Buffalo, USA) provided IR-photos. Alfons H.M. VandenBerg (Museum of Victoria, Melbourne, Australia) supported the work with photos of Australian material. Museum specimens from the British Geological Survey, Nottingham (Michael Howe), GSC Canada, Ottawa, Ontario, Canada (Michelle Coyne, Jean Dougherty), Field Museum, Chicago, USA (Paul Mayer), Lund University (Mats Eriksson, Per Ahlberg), Nanjing Institute of Geology and Paleontology (Zhang Yuandong, Ma Xuan), Royal Belgian Institute of Natural Sciences, Brussels, Belgium (Annelise Folie), Senckenberg Naturmuseum, Frankfurt/Main (Michael Ricker, Eberhard Schindler) are acknowledged. Lukáš Laibl (Lausanne, Switzerland) accompanied fieldwork in Newfoundland. Anna Kozłowska (Warsaw, Poland) provided the Fenxiang graptolite material. Jo Sullivan (Buffalo, New York, USA) organized fieldwork in New York State to collect from the Medusaegraptus epibole. Ennie Schulze \& Pascal Olschewski (FU Berlin, Germany) joined fieldwork in western Newfoundland and collected important specimens. Jan Evers (FU Berlin, Germany) helped with SEM work. This paper is a contribution to IGCP project 653 - "The onset of the Great Ordovician Biodiversification Event".

\section{Fossil Repositories}

Illustrated material originates from the following institutions: AA - Faculty of Sciences and Technics, Cadi-Ayyad University, Marrakesh, Morocco; FMNH - The Field Museum, Department of Geology, Chicago, USA; GSC - Geological Survey of Canada, Ottawa, Canada; GSE - British Geological Survey, Keyworth, Nottingham, UK; IANIGLA - CONICET Mendoza, Argentina; LO - Department of Geology, Lund University, Sweden; NIGP - Nanjing Institute of Geology and Palaeontology, Nanjing, China; NMVP - Museum Victoria, Australia; NRM PZ - Naturhistoriska Riksmuseet, Stockholm, Sweden; PMO - Natural History Museum, University of Oslo, Norway; PMU - Museum of Evolution, Uppsala, Sweden; PŠ - Petr Štorch collection, Czech Geological Survey, Prague; SGU Sveriges Geologiska Undersökning, Uppsala, Sweden; SM Sedgwick Museum of Earth Sciences, Cambridge, UK; SMF - Senckenberg Naturmuseum, Frankfurt/Main, Germany; USNM - US National Museum, Washington, USA.

\section{References}

Agassiz, A. 1873. The history of Balanoglossus and Tornaria. Memoirs of the American Academy of Arts and Sciences, New Series 9(2), 421-436. DOI 10.2307/25058009 
Ainsworth, N.R., Burnett, R.D. \& Kontrovitz, M. 1990. Ostracod colour change by thermal alteration, offshore Ireland and Western UK. Marine Petrology and Geology 7, 288-297. DOI 10.1016/0264-8172(90)90006-3

Alessandrello, A., Bracchi, G. \& Riou, B. 2004. Polychaete, sipunculan and enteropneust worms from the Lower Callovian (Middle Jurassic) of La Voulte-sur-Rhône (Ardeche, France). Memorie della Società Italiana di Scienze Naturali e del Museo Civico di Storia Naturale di Milano 32(1), 1-16.

Andres, D. 1977. Graptolithen aus ordovizischen Geschieben und die frühe Stammesgeschichte der Graptolithen. Paläontologische Zeitschrift 51(1-2), 52-93.

DOI 10.1007/BF02986602

Andres, D. 1980. Feinstrukturen und Verwandtschaftsbeziehungen der Graptolithen. Paläontologische Zeitschrift 54(1-2), 129-170. DOI 10.1007/BF02985886

Arduini, P., Pinna, G. \& Teruzzi, G. 1981. Megaderaion sinemuriense, n. g., n. sp., a new fossil enteropneust of the Sinemurian of Osteno in Lombardy. Atti della Società Italiana de Scienze Naturale e del Museo Civico di Storia Naturale de Milano 122, 104-108.

Baird, G.C., Sroka, S.D., Shabica, C.W. \& Kuecher, G.J. 1986. Taphonomy of Middle Pennsylvanian Mazon Creek area fossil localities, northeast Illinois: Significance of exceptional fossil preservation in syngenetic concretions. Palaios 1(3), 271-285. DOI $10.2307 / 3514690$

Baliński, A. \& Sun, Y. 2013. Preservation of soft tissues in an Ordovician linguloid brachiopod from China. Acta Palaeontologica Polonica 58, 115-120. DOI 10.4202/app.2012.0088

Baliński, A. \& Sun, Y. 2015. Fenxiang biota: a new early Ordovician shallow-water fauna with soft-part preservation from China. Science Bulletin 60(8), 812-818. DOI 10.1007/s11434-015-0762-7

BALIŃSKI, A. \& Sun, Y. 2017. Early Ordovician black corals from China. Bulletin of Geosciences 92(1), 1-12. DOI 10.3140/bull.geosci.1632

Baliński, A., Sun, Y. \& DziK, J. 2012. 470-Million-year-old black corals from China. Naturwissenschaften 99, 645-653. DOI 10.1007/s00114-012-0947-8

BALIŃSKi, A., Sun, Y. \& DZIK, J. 2014. Probable advanced hydroid from the Early Ordovician of China. Paläontologische Zeitschrift 88, 1-10. DOI 10.1007/s12542-013-0169-1

Bancroft, A.M., Kleffnner, M.A. \& Brunton, F.R. 2016. Biochemostratigraphy of the Eramosa Formation in southwestern Ontario, Canada. Canadian Journal of Earth Sciences 53, 749-762. DOI 10.1139/cjes-2015-0223

BARDACK, D. 1997. Wormlike animals: Enteropeusta, 89-92. In ShabicA, C.W. \& Hay, A.A. (eds) Richardson's Guide to the fossil fauna of Mazon Creek. Northeastern Illinois University, Chicago.

Bassler, R.S. 1909. Dendroid graptolites of the Niagaran dolomites at Hamilton, Ontario. United States National Museum Bulletin 65, 11-76. DOI 10.5479/si.03629236.65.i

Bates, D.E.B. \& UrbaneK, A. 2002. The ultrastructure, development, and systematic position of the graptolite genus Mastigograptus. Acta Palaeontologica Polonica 47(3), 445-458.
Beli, E., Piraino, S. \& Cameron, C.B. 2017. Fossilization processes of graptolites: insights from the experimental decay of Rhabdopleura sp. (Pterobranchia). Palaeontology 60(3), 389-400. DOI 10.1111/pala.12290

Bergström, S.M. 1980. Conodonts as paleotemperature tools in Ordovician rocks of the Caledonides and adjacent areas in Scandinavia and the British Isles. Geologiska Föreningen i Stockholm Förhandlinger 102(4), 377-392.

DOI 10.1080/11035898009454495

Bienkowska-Wasiluk, M., Uchman, A., Jurkowska, A. \& Swierczewska-GŁadysz, E. 2015. The trace fossil Lepidenteron lewesiensis: a taphonomic window on diversity of Late Cretaceous fishes. Paläontologische Zeitschrift 89, 795-806. DOI 10.1007/s12542-015-0260-x

Birker, I. \& KaYlor, J. 1986. Pyrite disease: Case studies from the Redpath Museum, 21-27. In Waddington, J. \& Rudkin, D.M. (eds) Proceedings of the 1985 Workshop on the Care and Maintenance of Natural History Collections. Royal Ontario Museum: Life Sciences Miscellaneous Publications. Alger Press, Toronto.

Buerreskov, M. 1978. Discoveries on graptolites by X-ray studies. Acta Palaeontologica Polonica 23, 463-471.

BJerreskov, M. 1991. Pyrite in Silurian graptolites from Bornholm, Denmark. Lethaia 24, 351-361.

DOI 10.1111/j.1502-3931.1991.tb01486.x

BJerreskov, M. 1994. Pyrite diagenesis of graptolites from Bornholm, 217-222. In Chen, X., Erdtmann, B.-D. \& Ni, Y.-N. (eds) Graptolite Research Today. Nanjing University Press, Nanjing.

Blackett, E., Page, A., Zalasiewicz, J., Williams, M., Rickards, B. \& DAVIES, J. 2009. A refined graptolite biostratigraphy for the late Ordovician-early Silurian of central Wales. Lethaia 42, 83-96. DOI 10.1111/j.1502-3931.2008.00108.x

Botting, J.P. 2012. Reassessment of the problematic Burgess Shale sponge Takakkawia lineata Walcott, 1920. Canadian Journal of Earth Sciences 49, 1087-1095.

DOI 10.1139/e2012-046

BouČEK, B. 1932. Preliminary report on some new species of graptolites from the Gothlandian of Bohemia. Věstnik Státního geologického ústavu Československé republiky 8(3), 150-155.

Boulter, E. 2003. A new enteropneust-like hemichordate from the Middle Cambrian Burgess Shale. In Purnell, M. (ed.) $47^{\text {th }}$ Palaeontological Association Annual Meeting. University of Leicester (Oral presentations, Abstracts). https://pdfs.semanticscholar.org/d8dc/efb7a8334e48700017 acafb4c46d0966f056.pdf

BraucKmann, C. \& Herd, K.J. 2002. Insekten-Funde aus dem Westfalium D (Ober-Karbon) des Piesberges bei Osnabrück (Deutschland). Teil 1: Palaeoptera. Osnabrücker Naturwissenschaftliche Mitteilungen 28, 27-69.

Brett, C.E., Tepper, D.H., Goodman, W.M., LoDuca, S.T. \& ECKERT, B.-Y. 1995. Revised stratigraphy and correlations of the Niagaran provincial series (Medina, Clinton, and Lockport groups) in the type area of western New York. U.S. Geological Survey Bulletin 2086, 1-66.

BRIGGS, D.E.G. 2003. The role of decay and mineralization in the 
preservation of soft-bodied fossils. Annual Review of Earth and Planetary Sciences 31, 275-301.

DOI 10.1146/annurev.earth.31.100901.144746

Briggs, D.E.G. \& KeAR, A.J. 1993. Decay and preservation of polychaetes: taphonomic thresholds in soft-bodied organisms. Paleobiology 19(1), 107-135.

DOI 10.1017/S0094837300012343

Briggs, D.E.G. \& Williams, S.H. 1981. The restoration of flattened fossils. Lethaia 14, 157-164.

DOI /10.1111/j.1502-3931.1981.tb01918.x

Briggs, D.E.G., Erwin, D.H. \& Collier, F.J. 1994. The fossils of the Burgess Shale. 238 pp. Smithsonian Institution Press, Washington, D.C.

Briggs, D.E.G., Siveter, D.J. \& Siveter, D.J. 1996. Soft-bodied fossils from a Silurian volcaniclastic deposit. Nature 382, 248-250. DOI 10.1038/382248a0

Briggs, D.E.G., Kear, A.J., BaAs, M., De Leeuw, J.W. \& RigBY, S. 1995. Decay and composition of the hemichordate Rhabdopleura: implications for the taphonomy of graptolites. Lethaia 28, 15-23.

DOI 10.1111/j.1502-3931.1995.tb01589.x

BronN, H.G. 1835. Lethaea Geognostica, Erster Band, das Übergangs-, bis Oolithen-Gebirge enthaltend. 768 pp. Schweizerbart, Stuttgart.

Brunton, F.R. 2009. 25. Project Unit 08-004. Update of revisions to the early Silurian stratigraphy of the Niagara Escarpment: Integration of sequence stratigraphy, sedimentology and hydrogeology to delineate hydrogeologic units. Ontario Geological Survey, Open File Report 6240(25), 1-20.

Bulman, O.M.B. 1963. On Glyptograptus dentatus (Brongniart) and some allied species. Palaeontology 6(4), 665-689.

Bulman, O.M.B. 1970. Graptolithina. In Teichert, C. (ed.) Treatise on Invertebrate Paleontology, Part V. Second Edition. xxxii +163 pp. Geological Society of America \& University of Kansas Press, New York \& Lawrence.

Burkhard, M., Caritg, S., Helg, U., Robert-Charrue, C. \& Soulaimani, A. 2006. Tectonics of the Anti-Atlas of Morocco. Comptes Rendus Geosciences 338, 11-24.

DOI 10.1016/j.crte.2005.11.012

Butler, A.D., Cunningham, J.A., Budd, G.E. \& Donoghue, P.C.J. 2015. Experimental taphonomy of Artemia reveals the role of endogenous microbes in mediating decay and fossilization. Proceedings of the Royal Society B 282, art. 20150476. DOI 10.1098/rspb.2015.0476

Butterfield, N.J. 1990. Organic preservation of non-mineralizing organisms and the taphonomy of the Burgess Shale. Paleobiology 16, 272-286. DOI 10.1017 S0094837300009994

Butterfield, N.J. 1995. Secular distribution of Burgess Shaletype preservation. Lethaia $28,1-13$. DOI 10.1111/j.1502-3931.1995.tb01587.x

Butterfield, N.J. 2003. Exceptional fossil preservation and the Cambrian explosion. Integrative \& Comparative Biology 43, 166-177. DOI 10.1093/icb/43.1.166

Butterfield, N.J. \& Harvey, T.H.P. 2012. Small carbonaceous fossils (SCFs): A new measure of early Paleozoic paleobiology. Geology 40(1), 71-74. DOI 10.1130/G32580.1

Butterfield, N.J., Balthasar, U. \& Wilson, L.A. 2007. Fossil diagenesis in the Burgess Shale. Palaeontology 50(1), 5 37-543. DOI 10.1111/j.1475-4983.2007.00656.X

Cai, Y., Hua, H., Xiao, S., Schiffbauer, J.D. \& Li, P. 2010. Biostratinomy of the late Ediacaran pyritized Gaojiashan lagerstätte from southern Shaanxi, South China: importance of event deposits. Palaios 25, 487-506.

DOI 10.2110/palo.2009.p09-133r

Cameron, C.B. 2016. Saccoglossus testa from the Mazon Creek fauna (Pennsylvanian of Illinois) and the evolution of acorn worms (Enteropneusta: Hemichordata). Palaeontology 59, 329-336. DOI 10.1111/pala.12235

Cameron, C.B. 2018. Part V, Second revision, Chapter 2: Class Enteropneusta: Introduction, morphology, life habits, systematic descriptions, and future research. Treatise Online $109,1-22$.

Cameron, C.B. \& Ostiguy, A. 2013. Three new species of Glossobalanus (Hemichordata: Enteropneusta: Ptychoderidae) from western North America. Zootaxa 3630(1), 143-154. DOI 10.11646/zootaxa.3630.1.5

Caron, J.-B., Morris, S.C. \& Cameron, C.B. 2013. Tubicolous enteropneusts from the Cambrian period. Nature 495, 503-506. DOI 10.1038/nature12017

Caron, J.-B., Rudkin, D.M. \& Milliken, S. 2004. A new late Silurian (Pridolian) naraoiid (Euarthropoda: Nektaspida) from the Bertie Formaiton of southern Ontario, Canada - delayed fallout from the Cambrian explosion. Journal of Paleontology 78(6), 1138-1145.

DOI 10.1666/0022-3360(2004)078<1138:ANLSPN >2.0.CO;2

Caster, K.E. \& Kuellesvig-Waering, E.N. 1955. Family Megalograptidae Caster, K.E. \& Kjellesvig-Waering, E.N. 1955, p. P36. In Moore, R.C. (ed.) Treatise on Invertebrate Paleontology, Pt. P, Arthropoda 2. Geological Society of America and University of Kansas Press, Lawrence.

Caritg, S., Burkhard, M., Ducommun, R., Helg, U., Kopp, L. \& Sue, C. 2004. Fold interference patterns in the late Palaeozoic Anti-Atlas belt of Morocco. Terra Nova 16, 27-37. DOI 10.1111/j.1365-3121.2003.00525.x

Chapman, F. 1919. On some hydroid remains of Lower Palaeozoic age from Monegetta, near Lancefield. Proceedings of the Royal Society of Victoria, New Series 2(31), 388-393.

Chapman, R.F. 1985. Structure of the digestive system, 165-212. In Kerkut, G.A. \& Gilbert, L.I. (eds) Comprehensive insect physiology biochemistry and pharmacology 4. Pergamon Press.

Chen, J.Y. \& Erdtmann, B.-D. 1991. Lower Cambrian fossil Lagerstätte from Chengjiang, Yunnan, China: Insights for reconstructing early metazoan life, 57-76. In SimONETTA, A.M. \& Morris, S.C. (eds) The Early Evolution of Metazoa and the Significance of Problematic Taxa. Cambridge University Press, Cambridge, United Kingdom.

Chen, X., Zhang, Y.-D., Goldman, D., Bergström, S.M., Fan, J., Wang, Z., Finney, S.C., Chen, Q. \& MA, X. (eds) 2016. Darriwilian to Katian (Ordovician) graptolites from Northwest China. 370 pp. Zhejiang Univesity Press and Elsevier.

Cherns, L., Wheeley, J.R. \& Wright, V.P. 2008. Taphonomic windows and molluscan preservation. Palaeogeography, Palaeoclimatology, Palaeoecology 270, 220-229.

DOI 10.1016/j.palaeo.2008.07.012 
CLARK, T.H. 1924. The Paleontology of the Beekmantown series at Levis, Quebec. Bulletin of American Paleontology 10(41), $1-151$.

Clements, T., Purnell, M.A. \& Gabbott, S. 2018. The Mazon Creek Lagerstätte: a diverse late Paleozoic ecosystem entombed within siderite concretions. Journal of the Geological Society, London 176, 1-11.

DOI 10.1144/jgs2018-088

Collette, J.H. \& Rudkin, D.M. 2010. Phyllocarid crustaceans from the Silurian Eramosa Lagerstätte (Ontario, Canada): taxonomy and functional morphology. Journal of Paleontology 84, 118-127. DOI 10.1666/08-174.1

Collom, C.J., Johnston, P.A. \& Powell, W.G. 2009. Reinterpretation of 'Middle' Cambrian stratigraphy of the rifted western Laurentian margin: Burgess Shale Formation and contiguous units (Sauk II megasequence), Rocky Mountains, Canada. Palaeogeography, Palaeoclimatology, Palaeoecology 277, 63-85. DOI 10.1016/j.palaeo.2009.02.012

Cooper, R.A., Rigby, S., Loydell, D.K. \& Bates, D.E.B. 2012. Palaeoecology of the Graptoloidea. Earth-Science Reviews 112, 23-41. DOI 10.1016/j.earscirev.2012.01.001

Crowther, P. 1981. The fine structure of graptolite periderm. Special Papers in Palaeontology 26, 1-119.

Crowther, P. \& Rickards, R.B. 1977. Cortical bandages and the graptolite zooid. Geologica et Palaeontologica 11, 9-46.

Cunningham, J.A., Vargas, K., Yin, Z., Bengtson, S. \& Donoghue, P.C.J. 2017. The Weng'an Biota (Doushantuo Formation): an Ediacaran window on soft-bodied and multicellular microorganisms. Journal of the Geological Society 174, 793-802. DOI 10.1144/jgs2016-142

Dalziel, I.W.D. 1979. The mythical graptolites of the South Orkney Islands. The Edinburgh Geologist 6, 2-9.

Darroch, S.A.F., Laflamme, M., Schiffbauer, J.D. \& Briggs, D.E.G. 2012. Experimental formation of a microbial death mask. Palaios 27, 293-303. DOI 10.2110/palo.2011.p11-059r

Dawydoff, C. 1948. Classe des Ptérobranches, 455-532. In Grassé, P.-P. (ed.) Traité de Zoologie (Anatomie, Systématique, Biologie). Tome XI: Echinodermes, Stomocordés, Protocordés.

Dieni, I., Giordano, D., Loydell, D.K. \& Sassi, F.P. 2005. Discovery of Llandovery (Silurian) graptolites and probable Devonian corals in the Southalpine Metamorphic basement of the Eastern Alps (Agordo, NE Italy). Geological Magazine 142(1), 1-5. DOI 10.1017/S0016756804009987

Dunlop, J.A., Brauckmann, C. \& Steur, H. 2008. A late Carboniferous fossil scorpion from the Piesberg, near Osnabrück, Germany. Fossil Record 11, 25-32. DOI 10.1002/mmng.200700010

Durman, P.N. \& Sennikov, N.V. 1993. A new rhabdopleurid hemichordate from the Middle Cambrian of Siberia. Palaeontology 36(2), 283-296.

Egenhoff, S. \& Maletz, J. 2007. Graptolites as indicators of maximum flooding surfaces in monotomous deep-water shelf successions. Palaios 22, 373-383. DOI 10.2110/palo.2005.p05-096r

EISEL, R. 1908. Über die Verdrückungen thüringisch-sächsischer Graptolithenformen. Zeitschrift für Naturwissenschaften 80 , 218-221.
EISENACK, A. 1951. Retioliten aus dem Graptolithengestein. Palaeontographica A 100(5-6), 129-163.

Eldijk, T.J.B. van, Wappler, T., Strother, P.K., Weijst, C.M.H. VAn DER, Rajaei, H., Visscher, H. \& Schootbrugge, B. van DE 2018. A Triassic-Jurassic window into the evolution of Lepidoptera. Science Advances 4(1), e 1701568. DOI 10.1126/sciadv. 1701568

Elles, G.L. \& Wood, E.M.R. 1901. A monograph of British graptolites. Part 1 - Dichograptidae. Palaeontographical Society Monograph 55(260), 1-54.

DOI 10.1080/02693445.1901.12035498

Elles, G.L. \& Wood, E.M.R. 1904. A monograph of British graptolites. Part 4 - Dichograptidae. Palaeontographical Society Monograph 58(277), 135-180.

DOI 10.1080/02693445.1904.12035515

Elles, G.L. \& Wood, E.M.R. 1906. A monograph of British graptolites, Part 5. Palaeontographical Society London Monograph 60(288), 1xxiii-xcvi, 181-216.

DOI $10.1080 / 02693445.1906 .12035526$

Elles, G.L. \& Wood, E.M.R. 1907. A monograph of British Graptolites. Part 6. Palaeontographical Society Monograph 61(297), xcvii-cxx, 217-272. DOI 10.1080/02693445.1907.12035535

Elles, G.L. \& Wood, E.M.R. 1908. A Monograph of British Graptolites. Part 7. Palaeontographical Society Monograph 62(305), cxxxi-cxlviii, 273-358.

DOI 10.1080/02693445.1908.12035543

Epstein, A.G., Epstein, J.B. \& Harris, L.D. 1977. Conodont Color Alteration - an index to Organic Metamorphism. Geological Survey Professional Paper 995, 1-27. DOI $10.3133 / \mathrm{pp} 995$

Erdtmann, B.-D. 1976. Middle Silurian dendroid communities in the inter-reefs of the North American Platform, 245-253. In Kaljo, D. \& Koren, T.N. (eds) Graptolites and Stratigraphy. Academy of Sciences of the Estonian SSR, Institute of Geology, Tallinn.

Erdtmann, B.-D. \& Prezbindowski, D.R. 1974. Niagaran (Middle Silurian) Interreef Fossil Burial Environments in Indiana. Neues Jahrbuch für Geologie und Paläontologie, Abhandlungen 144, 342-372.

Eriksson, M.E., Bergman, C.F. \& Jepsson, L. 2004. Silurian scolecodonts. Review of Palaeobotany and Palynology 131, 269-300. DOI 10.1016/j.revpalbo.2004.04.001

Eriksson, M., Parry, L.A. \& Rudkin, D.M. 2017. Earth's oldest ,Bobbitt worm' - gigantism in a Devonian eunicidan polychaete. Scientific Reports 7, art. 43061. DOI 10.1038/srep43061

FernÁndeZ-LópeZ, S.R. \& FernÁNDEZ-JaLVo, Y. 2002. The limit between biostratinomy and fossil diagenesis, 27-36. In De Renzi, M., Belichón, M., Penalver, E., Montoya, P. \& Márquez-Aliaga, A. (eds) Current Topics on Taphonomy and Fossilization 2002. Valencia, Spain.

FLoRKIN, M. 1969. Fossil shell "conchiolin" and other preserved biopolymers, 498-520. In Eglinton, G. \& Murphy, M.T. (eds) Organic Geochemistry. Springer Verlag. Berlin, Heidelberg, New York. DOI 10.1007/978-3-642-87734-6_25

Forchielli, A., Steiner, M., Hu, S.X. \& Keupp, H. 2012. Taph- 
onomy of Cambrian (Stage 3/4) sponges from Yunnan (South China). Bulletin of Geosciences 87(1), 133-142.

DOI 10.3140/bull.geosci.1225D

Forchielli, A., Steiner, M., Kasbohm, J., Hu, S. \& Keupp, H. 2014. Taphonomic traits of clay-hosted early Cambrian Burgess Shale-type fossil Lagerstätten in South China. Palaeogeography, Palaeoclimatology, Palaeoecology 398, 59-85. DOI 10.1016/j.palaeo.2013.08.001

Foucart, M.F., Bricteux-Grégoire, S., Jeuniaux, C. \& Florkin, M. 1965. Fossil proteins of graptolites. Life Sciences 4(4), 467-471. DOI 10.1016/0024-3205(65)90095-0

FrickHINGER, K.A. 1999. Die Fossilien von Solnhofen 2. 190 pp. Goldschneck Verlag, Weinstadt, Baden-Würtemberg.

Gabвott, S.E., Zalasiewicz, J. \& Collins, D. 2008. Sedimentation of the Phyllopod Bed within the Cambrian Burgess Shale Formation of British Columbia. Journal of the Geological Society, London 165, 307-318.

DOI 10.1144/0016-76492007-023

Gaines, R.R. 2014. Burgess Shale-type preservation and its distribution in Space and Time. The Palaeontological Society Papers 20, 123-146. DOI 10.1017/S1089332600002837

Gaines, R.R., Briggs, D.E.G. \& Zhao, Y.L. 2008. Cambrian Burgess Shale-type deposits share a common mode of fossilization. Geology 36(10), 755-758.

DOI 10.1130/G24961A.1

Gaines, R.R., Droser, M.L., OrR, P.J., Garson, D., Hammarlund, E., QI, C. \& CANFIELD, D.E. 2012a. Burgess shale-type biotas were not entirely burrowed away. Geology 40, 283-286. DOI $10.1130 / \mathrm{G} 32555.1$

Gaines, R.R., Hammarlund, E.U., Hou, X., Qi, C., Gabbott, S.E., Zhao, Y., Peng, J. \& Canfield, D.E. 2012b. Mechanism for Burgess Shale-type preservation. PNAS 109(14), 5180-5184. DOI 10.1073/pnas.1111784109

Ge, M., Zheng, Z. \& Li, Y. 1990. Research of the Ordovician and Silurian graptolites and graptolite-bearing strata from Ningxia and the neighbouring districts. 190 pp. 64 pls. Nanjing University Press, Nanjing.

Geinitz, H.B. 1852. Die Versteinerungen der Grauwackenformation in Sachsen und den angrenzenden LänderAbtheilungen. Heft 1. Die Silurische Formation. Die Graptolithen, ein monographischer Versuch zur Beurtheilung der Grauwackenformation in Sachsen und den angrenzenden Länderabtheilungen sowie der Silurischen Formation überhaupt. 58 pp. Verlag von Wilhelm Engelmann, Leipzig.

Goldman, D. \& Bergström, S.M. 1997. Late Ordovician graptolites from the North American midcontinent. Palaeontology 40(4), 965-1010.

Goldstein, A., Knight, J. \& Kimball, K. 1998. Deformed graptolites, finite strain and volume loss during cleavage formation in rocks of the Taconic Slate Belt, New York and Vermont. Journal of Structural Geology 20(12), 1769-1782. DOI 10.1016/S0191-8141(98)00083-2

GoodARZI, F. 1990. Graptolite reflectance and thermal maturity of lower Paleozoic rocks, 19-22. In Nuccio, V.F., BARKer, C.E. \& Dyson, S.J. (eds) Applications of thermal maturity studies to energy exploration. Eastwood Printers and Publishers. Denver, CO, United States.
Gortani, M. 1922. Faune Paleozoiche della Sardegna. I. Le graptoliti di Goni. Palaeontographia Italica 28, 51-67.

Gould, S.J. 1989. Wonderful Life. 347 pp. Norton W.W. \& Co., United States.

GreiLING, L. 1958. Graptolithen-Erhaltung in "weißer Kieselsäure”. Senckenbergiana lethaea 39(3-4), 289-299.

Gümbel, C.W. 1868. Ueber den Pyrophyllit als Versteinerungsmittel. Sitzungsberichte der königlich bayerischen Akademie der Wissenschaften zu München, Jahrgang 1868(1), 498-502.

GuptA, N.S. 2013. Biopolymers: a molecular paleontology approach. Molecular preservation in graptolites. Topics in Geobiology 38, 147-156.

DOI 10.1007/978-94-007-7936-5_9

Gupta, N.S. \& Briggs, D.E.G. 2011. Taphonomy of animal organic skeletons through time. Topics in Geobiology 32, 200-218.

Gupta, N.S. \& Summons, R.E. 2011. Fate of chitinous organisms in the geosphere. Topics in Geobiology 34, 133-151.

DOI 10.1007/978-90-481-9684-5_7

Gupta, N.S., Michels, R., Briggs, D.E.G., Evershed, R.P. \& PANCOST, R.D. 2006. The organic preservation of fossil arthropods: an experimental study. Proceedings of the Royal Society B 273, 2777-2783. DOI 10.1098/rspb.2006.3646

Gutiérrez-Marco, J.C. \& Martin, E.L.O. 2016. Biostratigraphy and palaeoecology of Lower Ordovician graptolites from the Fezouata Shale (Moroccan Anti-Atlas). Palaeogeography, Palaeoclimatology, Palaeoecology 460, 35-49. DOI 10.1016/j.palaeo.2016.07.026

Haberfelner, E. 1933. Muscle-scars of Monograptidae. American Journal of Science 148, 298-302.

DOI 10.2475/ajs.s5-25.148.298

Hadding, A. 1915. Der Mittlere Dicellograptus-Schiefer auf Bornholm. Lunds Universitets Arsskrift, Afdelning (Ny Följd 2) 11(4), 1-40.

Hall, J. 1843. Geology of New York. Part IV. Comprising the survey of the Fourth Geological District. 683 pp. Carroll \& Cook, Albany.

Hall, J. 1847. Descriptions of the organic remains of the lower division of the New New York system. New York Geological Survey, Palaeontology of New York. Volume 1. 338 pp. C. Van Benthuysen, New York. DOI /10.5962/bhl.title.66970

HaLl, J. 1861. Report of the Superintendent of the Geological Survey, exhibiting the progress of the work. (incl. Descriptions of new species of fossils; from the investigations of the survey; to accompany the report of progress made to his Excellency, Alexander $W$. Randall, on the $24^{\text {th }}$ day of December, 1860; pp. 9-52). 52 pp. R.A. Calkins \& Co., Madison, Wisconsin.

Hall, J. 1865. Figures and descriptions of Canadian organic remains. Decade II, Graptolites of the Quebec Group. Geological Survey of Canada. 154 pp. A.B. Dawson Brothers, Montreal.

HARKNESS, R. 1851. Description of the graptolites found in the Black Shales of Dumfriesshire. Quarterly Journal of the Geological Society of London 7, 58-65.

DOI 10.1144/GSL.JGS.1851.007.01-02.16 
HARris, W.J. 1933. Isograptus caduceus and its allies in Victoria. Proceedings of the Royal Society of Victoria, New Series 46, 79-114.

Harris, W.J. \& Thomas, D.E. 1935. Victorian graptolites, part 3. Proceedings of the Royal Society of Victoria, New Series 47, 288-313.

Hartkopf-Fröder, C., Königshof, P., Littke, R. \& SchwarzBAUER, J. 2015. Optical thermal maturity parameters and organic geochemical alteration at low grade diagenesis to anchimetamorphism: A review. International Journal of Coal Geology 150-151, 74-119. DOI 10.1016/j.coal.2015.06.005

Harvey, T.H.P., Ortega-Hernández, J., Lin, J.-P., Zhao, Y. \& ButTerfield, N.J. 2012. Burgess Shale-type microfossils from the middle Cambrian Kaili Formation, Guizhou Province, China. Acta Palaeontologica Polonica 57(2), 423-436. DOI 10.4202/app.2011.0028

Heidenhain, F. 1869. Ueber Graptolithen führende DiluvialGeschiebe der norddeutschen Ebene. Zeitschrift der Deutschen Geologischen Gesellschaft 21, 143-182.

Helg, U., Burkhard, M., Caritg, S. \& Robert-Charrue, C. 2004. Folding and inversion tectonics in the Anti-Atlas. Tectonics 23, art. TC4006, 17 pp. DOI 10.1029/2003TC001576

Hills, E.S. \& Thomas, D.E. 1944. Deformation of graptolites and sandstones in slates from Victoria, Australia. Geological Magazine 81, 216-222. DOI 10.1017/S001675680007566X

Hisinger, W. 1837. Lethaea Suecica seu Petrificata Suecica, Supplementum 1. 124 pp. DA Norstedt et filii, Stockhom.

HoffKnecht, A. 1991. Mikropetrographische, organischgeochemische, mikrothermometrische und mineralogische Untersuchungen zur Bestimmung der organischen Reife von Graptolithen-Periderm. Göttinger Arbeiten zur Geologie und Paläontologie 48, 1-98.

Holland, N.D., Osborn, K.J. \& Kuhnz, L.A. 2012. A new deepsea species of harrimaniid enteropneust (Hemichordata). Proceedings of the Biological Society of Washington 125(3), 228-240. DOI 10.2988/12-11.1

Holland, N.D., Osborn, K.J., Gebruk, A.V. \& Rogacheva, A. 2013. Rediscovery and augmented description of the HMS 'Challenger' acorn worm (Hemichordata, Enteropneusta), Glandiceps abyssicola, in the equatorial Atlantic abyss. Journal of the Marine Biological Association of the United Kingdom 93(8), 2197-2205.

DOI $10.1017 / \mathrm{S} 0025315413000684$

Horstig, G. von 1952. Neue Graptolithen-Funde in gotlandischen Lyditen des Frankenwaldes und ihre Erhaltung in weißer Kieselsäure. Senckenbergiana 33(4-6), 345-351.

Hou, L., Zhou, Z., Gu, Y. \& Zhang, H. 1995. Confuciusornis sanctus, a new Late Jurassic sauriurine bird from China. Chinese Science Bulletin 40(18), 1545-1551.

Hou, X.G., Ramsköld, L. \& Bergström, J. 1991. Composition and preservation of the Chengjiang fauna - a Lower Cambrian soft-bodied biota. Zoologica Scripta 20(4), 395-411. DOI 10.1111/j.1463-6409.1991.tb00303.x

Hou, X.G., Aldridge, R.J., Bergström, J., Siveter, D.J. \& Feng, X. 2004. The Cambrian Fossils of Chengjang, China. 233 pp. Blackwell Science Ltd.

Hou,X.G.,Aldridge,R.J.,Siveter,D.J.,Siveter,D.J., Williams,M.,
Zalasiewicz, J., MA, X.Y. 2011. An early Cambrian hemichordate zooid. Current Biology 21, 612-616.

DOI 10.1016/j.cub.2011.03.005

Hsü, S.C. \& MA, C.T. 1948. The Ichang Formation and the Ichangian fauna. Bulletin of the National Research Institute of Geology, Academia Sinica 8, 1-51.

HundT, R. 1934. Kieselsäureerhaltung bei obersilurischen Graptolithen aus dem gemengten Diluvium Mitteldeutschlands. Zeitschrift für Geschiebeforschung 10(2), 101-104.

Hund, R. 1946. In Kieselsäure erhaltene Graptolithen aus dem Ostthüringer Gotlandium. Ostthüringer Geologie 2, 62-63.

Hundt, R. 1951. Beitrag zur Kenntnis der mitteldeutschen Graptolithenfauna aus dem Weinbergbruch bei Hohenleuben und dem Hässlich bei Weckersdorf. Jahrbuch des Kreismuseums Hohenleuben-Reichenfels 1, 46-61.

Hund, R. 1957. Seltene Gerölle in Kiesgruben (Graptolithen in Kieselsäure erhalten). Steinbruch und Sandgrube 50(8), 299-302.

HutT, J.E. 1974. The development of Clonograptus tenellus and Adelograptus hunnebergensis. Lethaia 7, 79-92. DOI 10.1111/j.1502-3931.1974.tb00887.x

Hutt, J.E., Rickards, R.B. \& Skevington, D. 1970. Isolated Silurian graptolites from the Bollerup and Klubbudden Stages of Dalarna, Sweden. Geologica et Palaeontologica 4, 1-23.

Inan, S., Goodarzi, F., Schmidt Mumm, A., Arouri, K., Qathami, S., Ardakani, O.H., Inan, T. \& Tuwailib, A.A. 2016. The Silurian Qusaiba Hot shales of Saudi Arabia: an integrated assessment of thermal maturity. International Journal of Coal Geology 159, 107-119. DOI 10.1016/j.coal.2016.04.004

JAANusson, V. 1960. The Viruan (Middle Ordovician) of Öland. Bulletin of the Geological Institutions of the University of Uppsala 38, 207-288.

JACKSON, D.E. 1967. Psigraptus, a new graptolite genus from the Tremadocian of Yukon, Canada. Geological Magazine 104(4), 317-321. DOI 10.1017/S0016756800048901

Jenkins, C.J. 1980. Maeandrograptus schmalenseei and its bearing on the origin of the diplograptids. Lethaia 13(4), 289-302. DOI 10.1111/j.1502-3931.1980.tb01054.x

JenKIns, C.J. 1987. The Ordovician graptoloid Didymograptus murchisoni in South Wales and its use in three dimensional absolute strain analysis. Transactions of the Royal Society of Edinburgh, Earth Sciences 78, 105-114. DOI $10.1017 / \mathrm{S} 0263593300011019$

JI, Q. \& JI, S. 1996. On the discovery of the earliest fossil bird in China (Sinosauropteryx gen. nov.) and the origin of birds. Chinese Geology 233, 30-33.

Johnston, K.J., Johnston, P.A. \& Powell, W.G. 2009a. A new, Middle Cambrian, Burgess Shale-type biota, Bolaspidella Zone, Chancellor Basin, southeastern British Columbia. Palaeogeography, Palaeoclimatology, Palaeoecology 277, 106-126. DOI 10.1016/j.palaeo.2009.02.015

Johnston, P.A., Johnston, K.J., Collom, C.J., Powell, W.G. \& Pollock, R.J. 2009b. Palaeontology and depositional environments of ancient brine seeps in the Middle Cambrian Burgess Shale at The Monarch, British Columbia, Canada. Palaeogeography, Palaeoclimatology, Palaeoecology 277, 86-105. DOI 10.1016/j.palaeo.2009.02.013 
Jones, H., Zalasiewicz, J. \& Rickards, B. 2002. Clingfilm preservation of spiraliform graptolites: evidence of organically sealed Silurian seafloors. Geology 30(4), 343-346.

DOI 10.1130/0091-7613(2002)030<0343:CPOSGE $>2.0 . C O ; 2$

Keupp, H., Doppelstein, B. \& Maletz, J. 2016. First evidence of in situ rhabdopleurids (Pterobranchia, Hemichordata) from the Lower Jurassic of southern Germany. Neues Jahrbuch für Geologie und Paläontologie, Abhandlungen 282(3), 263-269. DOI 10.1127/njgpa/2016/0617

Kielan-JaWorowska, Z. 1966. Polychaete jaw apparatuses from the Ordovician and Silurian of Poland and a comparison with modern forms. Palaeontologia Polonica 16, 1-152.

KIRK, N.H. 1979. Thoughts on coloniality in the Graptolithina, 411-432. In Larwood, G. \& Rosen, B.R. (eds) Biology and Systematics of Colonial Organisms. Systematics Association Special volume 11.

KIRSTE, E. 1919. Die Graptolithen des Altenburger Ostkreises. Mitteilungen aus dem Osterlande LVI, 60-222.

Kloss, T.J., Dornbos, S.Q., Chen, J.-Y., McHenry, L.J. \& Marenco, P.J. 2017. High-resolution geochemical evidence for oxic bottom waters in three Cambrian Burgess Shaletype deposits. Palaeogeography, Palaeoclimatology, Palaeoecology 440,90-95.DOI 10.1016/j.palaeo.2015.08.048

KLuessendorf, J. 1994. Predictability of Silurian Fossil-Konservat-Lagerstätten in North America. Lethaia 27, 337-344. DOI 10.1111/j.1502-3931.1994.tb01584.x

Kobell, Franz von 1870. Der Gümbelit, ein neues Mineral von Nordhalben bei Steben in Oberfranken. Sitzungsberichte der königlich bayerischen Akademie der Wissenschaften zu München, Jahrgang 1870(1), 294-296.

KöNIGSHOF, P. 2003. Conodont deformation patterns and textural alteration in Paleozoic conodonts: examples from Germany and France. Senckenbergiana lethaea 83(1-2), 149-156. DOI 10.1007/BF03043310

KowalewsKi, M. 1996. Time-averaging, overcompleteness, and the geological record. The Journal of Geology 104, 317-326. DOI 10.1086/629827

KozŁowska-Dawidziuk, A. 2004. Evolution of retiolitid graptolites - a synopsis. Acta Palaeontologica Polonica 49(4), 505-518.

KozŁowski, R. 1962. Crustoidea-nouveau groupe des graptolites. Acta Palaeontologica Polonica 7(1-2), 3-52.

KrINGS, M. \& KerP, H. 2006. Neuropteris attenuata, a narrowstemmed, leaning or lianescent seed fern from the Upper Pennsylvanian of Lower Saxony, Germany. Flora 201, 233-239. DOI 10.1016/j.flora.2005.07.005

LaFlamme, M., Schiffbauer, J.D. \& Darroch, S.A.F. (eds) 2014. Reading and writing of the fossil record: preservational pathways to exceptional fossilization: presented as a Paleontological Society short course at the annual meeting of the Geological Society of America, Vancouver, British Columbia, October 18. 2014. Paleontological Society Papers 20. DOI 10.1017/S108933260000276X

LANKESTER, E.R. 1884. A contribution to the knowledge of Rhabdopleura. Quarterly Journal of Microscopical Science 24, 622-647.

Lapworth, C. 1876. The Silurian System in the South of
Scotland, 1-28. In Armstrong, J., Young, J. \& Robertson, D. (eds) Catalogue of Western Scottish Fossils. Blackie and Son, Glasgow.

Lapworth, C. 1877. The graptolites of County Down. Proceedings of the Belfast Naturalists' Field Club (Appendix) 1876-77, 125-144.

Lefebvre, B., Guensburg, T.E., Martin, E.L.O., Mooi, R., Nardin, E., Nohejlová, M., Kouraïss, K., El Hariri, K. \& DAVID, B. 2019. Exceptionally preserved soft parts in fossils from the Lower Ordovician of Morocco clarify stylophoran affinities within basal deuterostomes. Geobios 52, 27-36. DOI 10.1016/j.geobios.2018.11.001

LEGG, D. 1976. Ordovician trilobites and graptolites from the Canning Basin, western Australia. Geologica et Palaeontologica 10, 1-58.

LEGRAND, P. 1964a. Un graptolite remarquable de l'ordovicien inferieur du Sahara algerien, Choristograptus louhai nov. gen., nov. sp. Bulletin de la Societe Geologique de France 5(1), 52-57.

Legrand, P. 1964b. Deux nouvelles espèces du genre Adelograptus (Graptolites) dans L'Ordovicien inférieur du Sahara algérien. Bulletin de la Societé Géologique de France, Compte Rendu Sommaire 7(6), 295-304.

Legrand, P. 1974. Development of rhabdosomes with four primary branches in the group Dictyonema flabelliforme (EICHWALD). Special Papers in Palaeontology 13, 19-34.

Lehnert, O., Nowak, H., Sarmiento, G.N., Gutiérrez-Marco, J.C., Akodad, M. \& Servais, T. 2016. Conodonts from the Lower Ordovician of Morocco - Contributions to age and faunal diversity of the Fezouata lagerstätte and peri-Gondwana biogeography. Palaeogeography, Palaeoclimatology, Palaeoecology 460, 50-61.

DOI 10.1016/j.palaeo.2016.03.023

Lenz, A.C. \& KozŁowska, A. 2006. Graptolites from the lundgreni Biozone (Lower Homerian: Silurian), Arctic Islands, Canada: new species and supplementary material. Journal of Paleontology 80(4), 616-637. DOI 10.1666/0022-3360(2006)80[616:GFTLBL]2.0.CO;2

Lenz, A.C. \& Melchin, M.J. 1987. Silurian retiolitids from the Cape Phillips Formation, Arctic Islands, Canada. Bulletin of the Geological Society of Denmark 35, 161-170.

Lindholm, K. 1991. Ordovician graptolites from the early Hunneberg of southern Scandinavia. Palaeontology 34(2), 283-327.

LinNARSSON, J.G.O. 1871. Om nagra försteningar fran Sveriges och Norges Primordialzon. Öfversigt af Konglika VetenskapsAkademiens Förhandlingar 6, 789-797.

Liu, J., Steiner, M., Dunlop, J.A. \& Shu, D.-G. 2018. Microbial decay analysis challenges the interpretation of putative organ systems in Cambrian fuxianhuiids. Proceedings of the Royal Society B 285, 1-10. DOI 10.1098/rspb.2018.0051

LoDuca, S.T. 1990. Medusaegraptus mirabilis Ruedemann as a noncalcified dasyclad alga. Journal of Paleontology 64, 469-474. DOI 10.1017/S0022336000018710

LoDucA, S.T. \& BRETt, C.E. 1991. Placement of the Wenlockian/ Ludlovian boundary in western New York State. Lethaia 24, 255-264. DOI 10.1111/j.1502-3931.1991.tb01476.x 
LoDuca, S.T. \& TETREAULT, D.K. 2017. Ontogeny and reproductive functional morphology of the macroalga Wiartonella nodifera n. gen. n. sp. (Dasycladales, Chlorophyta) from the Silurian Eramosa Lagerstätte of Ontario, Canada. Journal of Paleontology 81(1), 1-11. DOI 10.1017/jpa.2016.144

LoDuca, S.T., Caron, J.-B., Schiffbauer, J.D., Xiao, S. \& Kramer, A. 2015. A reexamination of Yuknessia from the Cambrian of British Columbia. Journal of Paleontology 89(1), 82-95. DOI 10.1017/jpa.2014.7

LoYDELL, D.K. 1991. Isolated graptolites from the Llandovery of Kallholen, Sweden. Palaeontology 34(3), 671-693.

Loydell, D.K. \& Maletz, J. 2004. The Silurian graptolite genera Streptograptus and Pseudostreptograptus. Journal of Systematic Palaeontology 2(2), 65-93.

DOI $10.1017 /$ S1477201904001117

Loydell, D.K. \& Maletz, J. 2009. Isolated graptolites from the Lituigraptus convolutus Biozone (Silurian, Llandovery) of Dalarna, Sweden. Palaeontology 52(2), 273-296. DOI 10.1111/j.1475-4983.2008.00843.x

Loydell, D.K., OrR, P.J. \& Kearns, S. 2004. Preservation of soft tissues in Silurian graptolites from Latvia. Palaeontology 47(3), 503-513. DOI 10.1111/j.0031-0239.2004.00381.x

M'Coy, F. 1850. On some new genera and species of Silurian Radiata in the Collection of the University of Cambridge. Annals and Magazine of Natural History, Series 2(6), 270-290.

M'Intosh, W.C. 1887. Report on Cephalodiscus dodecalophus, M'Intosh, a new type of the Polyzoa, procured on the voyage of H.M.S. Challenger during the years 1873-76 (with an appendix, p. 38-47, by S. Harmer on the anatomy of Cephalodiscus). Challenger Reports, Zoology 20, 1-47.

MacGabhan, B.A. 2014. There is no such thing as the 'Eadiacara Biota'. Geoscience Frontiers 5, 53-62.

DOI 10.1016/j.gsf.2013.08.001

Maletz, J. 1994. The rhabdosome architecture of Pterograptus (Graptoloidea, Dichograptidae). Neues Jahrbuch für Geologie und Paläontologie, Abhandlungen 191(3), 345-356.

MaletZ, J. 1997. Ordovician and Silurian strata of the G-14 well (Baltic sea): graptolite faunas and biostratigraphy. Zeitschrift für geologische Wissenschaften 25(1-2), 29-39.

Maletz, J. 2008. Retiolitid graptolites from the collection of Hermann Jaeger in the Museum für Naturkunde, Berlin (Germany). I. Neogothograptus and Holoretiolites. Paläontologische Zeitschrift 82(3), 285-307.

DOI 10.1007/BF02988896

Maletz, J. 2009. Holmograptus spinosus and the Middle Ordovician (Darriwilian) graptolite biostratigraphy at Les Méchins (Quebec, Canada). Canadian Journal of Earth Sciences 46, 739-755. DOI 10.1139/E09-048

Maletz, J. 2010a. Retiolitid graptolites from the collection of Hermann Jaeger II; Cometograptus, Spinograptus and Plectograptus. Paläontologische Zeitschrift 84, 501-522. DOI 10.1007/s12542-010-0065-x

MaLETZ, J. 2010b. Xiphograptus and the evolution of the virgellabearing graptoloids. Palaeontology 53(2), 415-439.

DOI 10.1111/j.1475-4983.2010.00940.x

Maletz, J. 2011. Scandinavian Isograptids (Graptolithina,
Isograptidae): biostratigraphy and taxonomy. Proceedings of the Yorkshire Geological Society 58(4), 267-280.

DOI 10.1144/pygs.58.4.295

Maletz, J. 2014a. The classification of the Pterobranchia (Cephalodiscida and Graptolithina). Bulletin of Geosciences 89(3), 477-540. DOI 10.3140/bull.geosci.1465

Maletz, J. 2014b. Fossil Hemichordata (Pterobranchia, Enteropneusta). Palaeogeography, Palaeoclimatology, Palaeoecology 398, 16-27. DOI 10.1016/j.palaeo.2013.06.010

Maletz, J. 2015. Graptolite reconstructions and interpretations. Paläontologische Zeitschrift 89, 271-286. DOI 10.1007/s12542-014-0234-4

Maletz, J. 2017. Graptolite Paleobiology. 323 pp. Topics in Palaeobiology,Wiley-Blackwell. DOI 10.1002/9781118515624

Maletz, J. 2019a. Tracing the evolutionary origins of the Hemichordata (Enteropneusta and Pterobranchia). Palaeoworld 28, 58-72. DOI 10.1016/j.palwor.2018.07.002

Maletz, J. 2019b. Dictyonema Hall and its importance for the evolutionary history of the Graptoloidea. Palaeontology 62(1), 151-161. DOI 10.1111/pala.12394

Maletz, J. \& Beli, E. 2018. Treatise on Invertebrate Paleontology, Part V, Second Revision, Chapter 15: Subclass Graptolithina and incertae sedis family Rhabdopleuridae: Introduction and systematic descriptions. Treatise Online 101, 1-14.

DOI 10.17161/to.v0i0.7053

Maletz, J. \& Cameron, C.B. 2016. Treatise on Invertebrate Paleontology, Part V, Second revision, Chapter 3: Introduction to the Class Pterobranchia Lankester, 1877. Treatise Online 82, 1-15. DOI 10.17161/to.v0i0.6476

Maletz, J. \& KozŁowsKa, A. 2013. Ordovician graptolites from the Yichang area, Hubei, China. Paläontologische Zeitschrift 87(4), 445-454. DOI 10.1007/s12542-013-0174-4

MaletZ, J. \& SchÖNInG, H. 2017. Graptolites from glacial erratics of the Laerheide, northern Germany. Paläontologische Zeitschrift 91, 223-235. DOI 10.1007/s12542-017-0345-9

Maletz, J. \& Steiner, M. 2015. Graptolite (Hemichordata, Pterobranchia) preservation and identification in the Cambrian Series 3. Palaeontology 58(6), 1073-1107.

DOI 10.1111/pala. 12200

Maletz, J., Lenz, A.C. \& Bates, D.E.B. 2016. Treatise on Invertebrate Paleontology, Part V, Second Revision, Chapter 4: Morphology of the Pterobranch Tubarium. Treatise Online 76, 1-63. DOI 10.17161/to.v0i0.5727

Maletz, J., Steiner, M. \& FatKa, O. 2005. Middle Cambrian pterobranchs and the question: What is a graptolite? Lethaia 38, 73-85. DOI 10.1080/00241160510013204

Maletz, J., Königshof, P., Meco, S. \& Schindler, E. 1998. Late Wenlock to Early Ludlow graptolites from Albania. Senckenbergiana lethaea 78(1-2), 141-151. DOI 10.1007/BF03042765

Maletz, J., Bates, D.E.B., Brussa, E.D., Cooper, R.A., Lenz, A.C., Riva, J.F., Toro, B.A. \& Zhang, Y.D. 2014. Treatise on Invertebrate Paleontology, Part V, revised, Chapter 12: Glossary of the Hemichordata. Treatise Online 62, 1-23. DOI 10.17161/to.v0i0.4710

Manda, Š., ŠTorch, P., FrÝdA, J., Slavík, L. \& TASÁRYovÁ, Z. 2019. 
The mid-Homerian (Silurian) biotic crisis in offshore settings of the Prague Synform, Czech Republic: Integration of the graptolite fossil record with conodonts, shelly fauna and carbon isotope data. Palaeogeography, Palaeoclimatology, Palaeoecology 528, 14-34.

DOI 10.1016/j.palaeo.2019.04.026

Martin, E., Pittet, B., Gutiérrez-Marco, J. C., Lefebvre, B., Vannier, J., El Hariri, K., Lerosey-Aubril, R., Masrour, M., Nowak, H., Servais, T., Vandenbroucke, T., Van Roy, P. \& Vaucher, R. 2016. The Lower Ordovician Fezouata Konservat-Lagerstätte from Morocco: age, environment and evolutionary perspectives. Gondwana Research 34, 274-283. DOI 10.1016/j.gr.2015.03.009

McKerrow, W.S., Leggett, J.M. \& Eales, M.H. 1977. Imbricate thrust model of the Southern Uplands of Scotland. Nature 267, 37-39. DOI 10.1038/267237a0

Melchin, M.J. \& ANDERson, A.J. 1998. Infrared video microscopy for the study of graptolites and other organic-walled fossils. Journal of Paleontology 72(2), 397-400.

DOI $10.1017 / \mathrm{S} 0022336000036374$

Melchin, M.J. \& DeMont, M.E. 1995. Possible propulsion modes in Graptoloidea: a new model for graptoloid locomotion. Paleobiology 21(1), 110-120.

DOI 10.1017/S0094837300013105

Meyer, M.B., Ganis, G.R., Wittmer, J.M., Zalasiewicz, J.A. \& De BAEts, K. 2018. A Late Ordovician planktic assemblage with exceptionally preserved soft-bodied problematica from the Martinsburg Formation, Pennsylvania. Palaios 33, 36-46. DOI 10.2110/palo.2017.036

Mierzejewski, P. 1986. Ultrastructure, taxonomy and affinities of some Ordovician and Silurian organic microfossils. Palaeontologia Polonica 47, 129-220.

Miller, S.A. 1874. Genus Megalograptus. The Cincinnati Quarterly Journal of Science 1, 343-346.

Mitchell, C.E., Brussa, E.D. \& Maletz, J. 2008. A mixed isograptid-didymograptid graptolite assemblage from the Middle Ordovician of west Gondwana (NW 652 Bolivia): implications for graptolite paleoecology. Journal of Paleontology 82(6), 1114-1126. DOI 10.1666/06-069.1

Mitchell, C.E., Melchin, M.J., Cameron, C.B. \& Maletz, J. 2013. Phylogenetic analysis reveals that Rhabdopleura is an extant graptolite. Lethaia 46, 34-56.

DOI 10.1111/j.1502-3931.2012.00319.x

Monsen, A. 1937. Die Graptolithenfauna im Unteren Didymograptus Schiefer (Phyllograptusschiefer) Norwegens. Norsk Geologisk Tidsskrift 16(2-4), 57-267.

Mu, A.T. 1957. Some new or little known graptolites from the Ningkuo Shale (Lower Ordovician) of Changshan, western Chekiang. Acta Palaeontologica Sinica 5(3), 369-437.

Mu, A.T., Lee, C.H., Geh, M.Y. \& Yin, J.X. 1962. Graptolites from Chilianshan. Geology of Chilianshan 4(2), 1-168.

MüNCH, A. 1951. Bestimmung und Einstufung der Graptolithen aus den Kieselschiefer-Geröllen des unteren Mains. Senckenbergiana 32, 159-169.

Murchison, R.I. 1839. The Silurian System, founded on geological researches in the counties of Salop, Hereford, Radnor, Montgomery, Caermarthen, Brecon, Pembroke, Monmouth,
Gloucester, Worcester, and Stratford; with descriptions of the coal-fields and overlying formations. Part 1.768 pp. John Murray, London. DOI 10.5962/bhl.title.88029

Murdock, D.J., Gabbott, S.E., \& Purnell, M.A. 2016. The impact of taphonomic data on phylogenetic resolution: Helenodora inopinata (Carboniferous, Mazon Creek Lagerstätte) and the onychophoran stem lineage. BMC Evolutionary Biology 16, art. 19, 14 pp. DOI 10.1186/s12862-016-0582-7

Murdock, D.J., Gabbott, S.E., Mayer, G. \& Purnell, M.A. 2014. Decay of velvet worms (Onychophora), and bias in the fossil record of lobopodians. BMC Evolutionary Biology 14, art. 222, 9 pp. DOI 10.1186/s12862-014-0222-z

Muscente, A.D., Schiffbauer, J.D., Broce, J., LaFlamme, M., O’Donnell, K., Boag, T.H., Meyer, M., Hawkins, A.D., Huntley, J.W., McNamara, M., MacKenzie, L.A., Stanley Jr., G.D., Hinman, N.W., Hofmann, M.H. \& Xiao, S. 2017. Exceptionally preserved fossil assemblages through geologic time and space. Gondwana Research 48, 164-188. DOI 10.1016/j.gr.2017.04.020

Nanglu, K., Caron, J.-B. \& Cameron, C.B. 2015. Using experimental decay of modern forms to reconstruct the early evolution and morphology of fossil enteropneusts. Paleobiology 41(3), 460-478. DOI 10.1017/pab.2015.11

Nanglu, K., Caron, J.-B., Morris, S.C. \& Cameron, C.B. 2016. Cambrian suspension-feeding tubicolous hemichordates. BMC Evolutionary Biology 14, art. 56. DOI 10.1186/s12915-016-0271-4

Newman, A. 1998. Pyrite oxidation and museum collections: A review of theory and conservation treatments. The Geological Curator 6(10), 363-371.

Nicholson, H.A. 1873. On some fossils from the Quebec Group of Point Lévis, Quebec. Annals and Magazine of Natural History, Series 4(11), 133-143. DOI 10.1080/00222937308696778

Nitecki, M.H. \& Schram, F.R. 1976. Etacystis communis, a fossil of uncertain affinities from the Mazon Creek Fauna (Pennsylvanian of Illinois). Journal of Paleontology 50(6), 1157-1161.

Nowlan, G.S. \& Barnes, C.R. 1987. Thermal maturation of Paleozoic strata in eastern Canada from conodont colour alterations index (CAI) data with implications for burial history, tectonic evolution, hotspot tracks and mineral and hydrocarbon explorations. Geological Survey of Canada, Bulletin 367, 1-47. DOI 10.4095/122453

Orr, P.J., Benton, M.J. \& Briggs, D.E.G. 2003. Post-Cambrian closure of the deep-water slope-basin taphonomic window. Geology 31(9), 769-772. DOI 10.1130/G19193.1

OrR, P.J., Briggs, D.E.G., Siveter, D.J. \& Siveter, D.J. 2000 b. Three-dimensional preservation of a non-biomineralized arthropod in concretions in Silurian volcaniclastic rocks from Herefordshire, England. Journal of the Geological Society, London 157, 173-186. DOI 10.1144/jgs.157.1.173

Orr, P.J., Siveter, D.J., Briggs, D.E.G., Siveter, D.J. \& Sutton, M.D. 2000a. A new arthropod from the Silurian KonservatLagerstätte of Herefordshire, UK. Proceedings of the Royal Society, London B 267, 1497-1504.

DOI 10.1098/rspb.2000.1170

Ou, Q., Han, J., Zhang, Z., Shu, D., Sun, G. \& Mayer, G. 2017. 
Three Cambrian fossils assembled into an extinct body plan of cnidarian affinity. PNAS 114(33), 8835-8840.

DOI 10.1073/pnas.1701650114

Oukassou, M., Saddiqi, O., Barbarand, J., Sebti, S., Baidder, L. \& Michard, A. 2012. Post-Variscan exhumation of the central Anti-Atlas (Morocco) constrained by zircon and apatite fission-track thermochronology. Terra Nova 25, 151-159. DOI 10.1111/ter.12019

PAGE, A. 2007. Graptolitic mudrocks and their implications for the taphonomy of organic compression fossils. 225 pp. Ph.D. thesis, University of Leicester, United Kingdom.

Page, A., Gabbott, S.E., Wilby, P.R. \& Zalasiewicz, J.A. 2008. Ubiquitous Burgess Shale-style 'clay templates' in low grade metamorphic mudrocks. Geology 36(11), 855-858.

DOI 10.1130/G24991A.1

Palmer, D. \& Rickards, B. 1991. Graptolites Writing in the Rock. 182 pp. 138 pls. The Boydell Press, Woodbridge, United Kingdom.

Parry, L.A., Smithwick, F., Norden, K.K., Saitta, E.T., LozanoFernandez, J., Tanner, A.R., Caron, J.-B., Edgecombe, G.D., Briggs, D.E.G. \& Vinther, J. 2017. Soft-bodied fossils are not simply rotten carcasses - toward a holistic understanding of exceptional fossil preservation. BioEssays 2017, 11 pp. DOI 10.1002/bies.201700167

PIRIE, J.H.H. 1905. On the graptolite-bearing rocks of the South Orkneys. Proceedings of the Royal Society of Edinburgh 25, 463-470. DOI 10.1017/S037016460000866X

Porter, S.M. 2004. Closing the phosphatization window: testing for the influence of taphonomic megabias on the pattern of small shelly fossil decline. Palaios 19(2), 178-183.

DOI 10.1669/0883-1351(2004)019<0178:CTPWTF $>2.0 . C O ; 2$

Powell, W. 2003. Greenschist-facies metamorphism of the Burgess Shale and its implications for models of fossil formation and preservation. Canadian Journal of Earth Sciences 40, 13-25. DOI 10.1139/e02-103

Powell, W.G., Johnston, P.A. \& Collom, C.J. 2003. Geochemical evidence for oxygenated bottom waters during deposition of fossiliferous strata of the Burgess Shale Formation. Palaeogeography, Palaeoclimatology, Palaeoecology 201, 249-268. DOI 10.1016/S0031-0182(03)00612-6

Pritchard, G.B. 1892. On a new species of Graptolitidae (Temnograptus magnificus). Proceedings of the Royal Society of Victoria, New Series 4, 56-58.

Purnell, M.A., Donghue, P.J.C., Gabbott, S.E., McNamara, M.E., Murdock, D.J.E. \& SAnsom, R.S. 2018. Experimental analysis of soft-tissue fossilization: opening the black box. Palaeontology 61(3), 317-323. DOI 10.1111/pala.12360

Radzevicius, S., Schopf, J.W. \& Kudryavtsev, A.B. 2013. Bacterial epibionts encrusting Silurian graptolites, 267-269. In Lindskog, A. \& Mehlquist, K. (eds) Proceedings of the $3^{\text {rd }}$ IGCP 591 Annual Meeting - Lund, Sweden, 9-19 June 2013.

Ramírez Guerrero, G. M. 2019. The systematics and evolution of Cambrian graptolites from the Burgess Shale of Canada. 59 pp. Master thesis, Université de Montréal, Canada.

Richter, Re. 1853. Thüringische Graptolithen. Zeitschrift der Deutschen Geologischen Gesellschaft 5, 439-464.
Richter, Re. 1871. Aus dem thüringischen Schiefergebirge. Zeitschrift der Deutschen Geologischen Gesellschaft 23, 231-256.

Richter, Ru. 1948. Gotlandischer Kieselschiefer mit Graptolith als Geröll bei Frankfurt a. M. Senckenbergiana 29, 101-107.

Richter, RU. 1951. Das gotlandische Alter von Kieselschiefern in den Geröllen des unteren Mains. Senckenbergiana 32(1-4), 155-169.

Rickards, R.B. \& Chapman, A. 1991. Bendigonian graptolites (Hemichordata) of Victoria. Memoirs of the Museum of Victoria 52(1), 1-135. DOI 10.24199/j.mmv.1991.52.01

Rickards, R.B. \& Stait, B.A. 1984. Psigraptus, its classification, evolution and zooid. Alcheringa 8, 101-111. DOI 10.1080/03115518408618936

Rickards, R.B., Partridge, P.L. \& Banks, M.R. 1991. Psigraptus jacksoni - systematics, reconstruction, distribution and preservation. Alcheringa 15, 243-254. DOI 10.1080/03115519108619022

RigBY, S. 1993a. Graptolite functional morphology: a discussion and critique. Modern Geology 17, 271-287.

RigbY, S. 1993b. Population analysis an dorientation studies of graptoloids from the Middle Ordovician Utica Shale, Quebec. Palaeontology 36(2), 267-282.

Rigby, S. \& Sudbury, M. 1995. Graptolite ontogeny and the size of the graptoloid zooid. Geological Magazine 132(4), 427-433. DOI 10.1017/S0016756800021488

Riva, J. 1970. Thrusted Paleozoic rocks in the northern and central HD Range, northeastern Nevada. Geological Society of America Bulletin 81, 2689-2716. DOI 10.1130/0016-7606(1970)81[2689:TPRITN]2.0.CO;2

Robert-Charrue, C. \& Burkhard, M. 2008. Inversion tectonics, interference pattern and extensional fault-related folding in the Eastern Anti-Atlas, Morocco. Swiss Journal of Geosciences 101, 397-408. DOI 10.1007/s00015-008-1266-0

Ruedemann, R. 1895. Development and the mode of growth of Diplograptus M'Coy. New York State Geological Survey Annual Report for 1894, 219-249.

Ruedemann, R. 1912. The Lower Siluric Shales of the Mohawk Valley. New York State Museum Bulletin 162(525), 1-151. DOI 10.5962/bhl.title.20499

Ruedemann, R. 1925. Some Silurian (Ontarian) faunas of New York. New York State Museum Bulletin 265, 1-134.

Ruedemann, R. 1931. Some new Middle Cambrian fossils from British Columbia. Proceedings of the United States National Museum 79(2893), 1-18. DOI 10.5479/si.00963801.79-2893.1

Ruedemann, R. 1947. Graptolites of North America. Geological Society of America Memoir 19, 1-652. DOI 10.1130/MEM19-p1

Ruiz, G.M.H., Helg, U., Negro, F., Adatte, T. \& Burkhard, M. 2008. Illite crystallinity patterns in the Anti-Atlas of Morocco. Swiss Journal of Geosciences 101, 387-395. DOI 10.1007/s00015-008-1267-Z

Ruiz, G.M.H., Sebti, S., Negro, F., Saddiqi, O., Frizon de Lamotte, D., Stockli, D., Foeken, J., Stuart, F., Barbarand, J. \& Schaer, J.-P. 2011. From central Atlantic continental rift to Neogene uplift - western Anti-Atlas, Morocco. Terra Nova 23, 35-41. DOI 10.1111/j.1365-3121.2010.00980.x 
Rushton, A.W.A. 2011. Deflexed didymograptids from the Lower Ordovician Skiddaw Group of northern England. Proceedings of the Yorkshire Geological Society 58, 319-327. DOI 10.1144/pygs.58.4.293

Saleh, F., Antcliffe, J.B., Lefebvre, B., Pittet, B., Laibl, L., Perez Peris, F., Lustri, L., Gueriau, P. \& Daley, A.C. 2020 b. Taphonomic bias in exceptionally preserved biotas. Earth and Planetary Science Letters 529, art. 115873, 6 pp.

DOI 10.1016/j.epsl.2019.115873

Saleh, F., Lefebvre, B., Hunter, A.W. \& Nohejlová, M. 2020a. Fossil weathering and preparation mimic soft tissues in eocrinoid and somasteroid echinoderms from the Lower Ordovician of Morocco. Microscopy Today 28(1), 2-5.

DOI 10.1017/S1551929519001238

SAlter, J.W. 1863. Notes on the Skiddaw Slate Fossils. Quarterly Journal of the Geological Society of London 19, 135-140.

SAnsom, R.S. 2014. Experimental decay of soft tissues. The Paleontological Society Papers 20, 259-274. DOI $10.1017 / \mathrm{S} 1089332600002886$

SAnsom, R.S. 2016. Preservation and phylogeny of Cambrian ecdysozoans tested by experimental decay of Priapulus. Scientific Reports 6, art. 32817, 12 pp. DOI 10.1038/srep32817

SARS, G.O. 1874. On Rhabdopleura mirabilis (M. Sars). Quarterly Journal of Microscopical Science (New Series) 14, $23-44$.

SATo, A. 2008. Seasonal reproductive activity in the pterobranch hemichordate Rhabdopleura compacta. Journal of the Marine Biological Association of the United Kingdom 88(5), 1033-1041. DOI 10.1017/S0025315408001604

SAunders, K.M., Bates, D.E.B., Kluessendorf, J., Loydell, D.K. \& Mikulic, D.G. 2009. Desmograptus micronematodes, a Silurian dendroid graptolite, and its ultrastructure. Palaeontology 52(3), 541-559.

DOI 10.1111/j.1475-4983.2009.00859.x

Schauer, M. 1971. Biostratigraphie und Taxionomie der Graptolithen des tieferen Silurs unter besonderer Berücksichtigung der tektonischen Deformation. Freiberger Forschungshefte C273, 1-185.

Schepotieff, A. 1904. Zur Organisation von Rhabdopleura. Vorläufige Mitteilung. Bergens Museums Aarbog 1904(2), $1-21$.

Schepotieff, A. 1906. Die Pterobranchier. Anatomische und histologische Untersuchungen über Rhabdopleura normanii Allman und Cephalodiscus dodecalophus M'Int. 1. Teil. Rhabdopleura normanii Allman. Die Anatomie von Rhabdopleura. Zoologische Jahrbücher. Abteilung für Anatomie und Ontogenie der Tiere 23, 463-534.

DOI 10.5962/bhl.part.21044

Schiffbauer, J.D., Wallace, A.F., Hunter, J.L., Kowalewski, M., Bodnar, R.J. \& XIAO, S. 2012. Thermally-induced structural and chemical alteration of organic-walled microfossils: An experimental approach to understanding fossil preservation in metasediments. Geobiology 10(5), 402-423.

DOI 10.1111/j.1472-4669.2012.00332.x

Schmidt Mumm, A. \& InAN, S. 2016. Microscale organic maturity determination of graptolites using Raman spectroscopy. International Journal of Coal Geology 162, 96-107.

DOI 10.1016/j.coal.2016.05.002
Seilacher, A. 1970. Begriff und Bedeutung der FossilLagerstätten. Neues Jahrbuch für Geologie und Paläontologie, Monatshefte 1970, 34-39.

SEnNiKov, N.V. 2016. Morphology of the exoskeleton and soft tissues of Cambrian rhabdopleurids. Paleontological Journal 50(14), 1626-1636. DOI 10.1134/S0031030116140070

Sewera, L.J. 2011. Determining the Composition of the Dwelling Tubes of Antarctic Pterobranchs. 26 pp. Honors thesis, Paper 48, Illinois Wesleyan University. http:// digitalcommons.iwu. edu/bio_honproj/48

Sherlock, S.C., Kelley, S.P., Zalasiewicz, J.A., Schofield, D.I., Evans, J.A., Merriman, R.J. \& Kemp, S.J. 2003. Precise dating of low-temperature deformation: strain-fringe analysis by ${ }^{40} \mathrm{Ar}-{ }^{39} \mathrm{Ar}$ laser microprobe. Geology 31(3), 119-122.

DOI 10.1130/0091-7613(2003)031<0219:PDOLTD>2.0.CO;2

SHrock, R.R. 1928. A new graptolite fauna from the Niagaran of northern Indiana. American Journal of Science 16, 1-38. DOI 10.2475/ajs.s5-16.91.1

Siveter, D.J., Fortey, R.A., Sutton, M.D., Briggs, D.E.G. \& Siveter, D.J. 2007. A Silurian 'marellomorph' arthropod. Proceedings of the Royal Society B 274, 2223-2229.

DOI 10.1098/rspb.2007.0712

Slater, B.J., Willman, S., Budd, G.E. \& Peel, J.S. 2017. Widespread preservation of small carbonaceous fossils (SCF's) in the early Cambrian of North Greenland. Geology 46(2), 107-110. DOI 10.1130/G39788.1

Soulaimani, A., Le Corre, Cl. \& FarazdaQ, R. 1997. Déformation hercynienne et relation socle/couverture dans le domaine du Bas-Drâa (Anti-Atlas occidental, Maroc). Journal of African Earth Sciences 24(3), 271-284.

DOI 10.1016/S0899-5362(97)00043-2

Spencer, J.W. 1884a. 1884a. Graptolites of the upper Silurian System (Niagara fossils). Bulletin of the Museum of the University of the State of Missouri 1, 555-610.

Spencer, J.W. 1884b. Niagara fossils. Part 1. Graptolitidae of the Upper Silurian System. Transactions of the Academy of Science of Saint Louis 4, 555-593.

Spengel, J.W. 1893. Monographie: Enteropneusten, 1-756. In Zoologische Station zu Neapel (eds) Fauna und Flora des Golfes von Neapel und der angrenzenden Meeres.

STEInER, M. 2018. How soft-tissued are Cambrian soft-bodied fossil lagerstätten? 95-96. International Conference on Ediacaran and Cambrian Sciences. 12 $2^{\text {th }} 16^{\text {th }}$ August 2018, Xi'an. Programme \& Abstracts.

Šтorch, P. 1998. Graptolites of the Pribylograptus leptotheca and Lituigraptus convolutus biozones of Tman (Silurian, Czech Republic). Journal of the Czech Geological Society 43(3), 209-272.

ŠTorch, P. 2015. Graptolites from the Rhuddanian-Aeronian boundary interval (Silurian), Prague Synform, Czech Republic. Bulletin of Geosciences 90(4), 841-891. DOI 10.3140/bull.geosci. 1568

Štorch, P. \& Kraft, P. 2009. Graptolite assemblages and stratigraphy of the lower Silurian Mrákotín Formation, Hlinsko Zone, NE interior of the Bohemian Massif (Czech Republic). Bulletin of Geosciences 84(1), 51-74.

DOI 10.3140/bull.geosci.1077 
Štorch, P., Manda, Š., Slavík, L. \& Tasáryová, Z. 2016. Wenlock-Ludlow boundary interval revisited: new insights from the offshore facies of the Prague synform, Czech Republic. Canadian Journal of Earth Sciences 53, 666-673. DOI 10.1139/cjes-2015-0161

Stouge, S. 1986. Conodont color variation in the Lower/Middle Ordovicin strata of western Newfoundland. Newfoundland Department of Mines \& Energy, Mineral Development Division Report 86-1, 177-178.

Sudbury, M. 1958. Triangulate Monograptids from the Monograptus gregarius zone (Lower Llandovery) of the Rheidol Gorge (Cardiganshire). Philosophical Transactions of the Royal Society of London, Series B. Geological Sciences 241(685), 485-555. DOI 10.1098/rstb.1958.0011

Suess, E. 1851. Über böhmische Graptolithen. Naturwissenschaftliche Abhandlungen von W. Haidinger 4(4), 87-134.

Tarhan, L.G., van SmeerdiJK Hood, A., Droser, M.L., Gehling, J.G. \& BRIGGS, D.E.G. 2016. Exceptional preservation of soft-bodied Ediacara Biota promoted by siliica-rich oceans. Geology 44(11), 951-954. DOI 10.1130/G38542.1

TeIchmüller, M. 1978. Nachweis von Graptolithen-Periderm in geschieferten Gesteinen mit Hilfe kohlenpetrologischer Methoden. Neues Jahrbuch für Geologie und Paläontologie, Monatshefte 1978(7), 430-447.

Tetreault, D.K. 2001. A new Silurian Konservat- Lagerstätte from the Eramosa Dolostone of the southern Bruce Peninsula, Ontario, Canada. 194 pp. Ph.D. thesis, University of Western Ontario, London.

TöRnQuist, S.L. 1890. Undersökningar öfven Siljansomradets Graptoliter 1. Lunds Universitets Arsskrift, New Series 26, $1-33$.

TÖRNQUist, S.L. 1892. Undersökningar öfven Siljansomradets Graptoliter 2. Lunds Universitets Arsskrift, New Series 28, $1-47$.

TöRnquist, S.L. 1893. Observations on the structure of some Diprionidae. Lunds Universitets Arsskrift 29, 1-14.

TöRnQuist, S.L. 1897. On the Diplograptidae and the Heteroprionidae of the Scanian Rastrites beds. Acta Regiae Societatis Physiographicae Lundensis 8, 1-22.

TöRnQuist, S.L. 1899. Researches into the Monograptidae of the Scanian Rastrites Beds. Lunds Universitets Arsskrift 35(1), $1-25$.

TöRnQUIST, S.L. 1901. Researches into the graptolites of the lower zones of the Scanian and Vestrogothian Phyllo-Tetragraptus beds, Part 1. Lunds Universitets Arsskrift 37(2), 1-25. [also Konglika Fysiografiska Sällskapets Handlingar 12(5)]

TörnQuist, S.L. 1907. The genus Rastrites and some allied species of Monograptus. Lunds Universitets Arsskrift, Ny Följd, Afdelningen 2, Bd. 3(5), 1-22.

Toro, B.A. \& Maletz, J. 2008. The proximal development in Cymatograptus (Graptoloidea) from Argentina and its relevance for the early evolution of the Dichograptacea. Journal of Paleontology 82(5), 974-983. DOI 10.1666/07-046.1

Towe, K.M. \& URBAneK, A. 1972. collagen-like structures in Ordovician graptolite periderm. Nature 237, 443-445.

DOI $10.1038 / 237443 \mathrm{a} 0$
Ulrich, E.O. \& Ruedemann, R. 1931. Are the graptolites bryozoans? Bulletin of the Geological Society of America 42, 589-604. DOI 10.1130/GSAB-42-589

Underwood, C.J. 1992. Graptolite preservation and Deformation. Palaios 7(2), 178-186. DOI 10.2307/3514928

Underwood, C.J. 1998. Population structure of graptolite assemblages. Lethaia 31, 33-41. DOI 10.1111/j.1502-3931.1998.tb00487.x

Underwood, C.J. \& Botrell, S.H. 1994. Diagenetic control on multiphase pyritization of graptolites. Geological Magazine 131, 315-327. DOI 10.1017/S0016756800011080

Urbanek, A. 1958. Monograptidae from erratic boulders of Poland. Acta Palaeontologica Polonica 9, 1-105.

Urbanek, A. \& Dilly, P. N. 2000. The stolon system in Rhabdopleura compacta (Hemichordata) and its phylogenetic implications. Acta Palaeontologica Polonica 45(3), 201-226.

VAn Roy, P., Briggs, D.E.G. \& Gaines, R.R. 2015. The Fezouata fossils of Morocco; an extraordinary record of marine life in the Early Ordovician. Journal of the Geological Society 172, 541-549. DOI 10.1144/jgs2015-017

Van Roy, P., Orr, P.J., Botting, J.P., Muir, L.A., Vinther, J., Lefebvre, B., el Hariri, K. \& Briggs, D.E.G. 2010. Ordovician faunas of Burgess Shale type. Nature 465, 215-218. DOI 10.1038/nature09038

Vannier, J., Racheboeuf, P.R., Brussa, E.D., Williams, M., Rushton, A.W.A., Servais, T. \& Siveter, D.J. 2003. Cosmopolitan arthropod zooplankton in the Ordovician seas. Palaeogeography, Palaeoclimatology, Palaeoecology 195, 173-191. DOI 10.1016/S0031-0182(03)00307-9

Vannier, J., Steiner, M., Renvoise, E., Hu, S.-X. \& Casanova, J.-P. 2007. Early Cambrian origin of modern food webs: evidence from predator arrow worms. Proceedings of the Royal Society B 274, 627-633. DOI 10.1098/rspb.2006.3761

Voldman, G.G., Albanesi, G.L. \& Do Campo, M. 2008. Conodont palaeothermometry of contact metamorphosis in Middle Ordovician rocks from the Precordillera of western Argentina. Geological Magazine 145(3), 449-462.

DOI 10.1017/S001675680800455X

von Bitter, P., Purnell, M.A., Tetreault, D.K. \& Stott, C.A. 2007. Eramosa Lagerstätte - Exceptionally preserved softbodied biotas with shallow-marine shelly and bioturbating organisms (Silurian, Ontario, Canada). Geology 35(10), 879-882. DOI 10.1130/G23894A.1

Waddington, J., Rudkin, D.M. \& Dunlop, J.A. 2015. A new midSilurian aquatic scorpion - one step closer to land? Biology Letters 11, art. 20140815. DOI 10.1098/rsbl.2014.0815

Walasek, N., Loydell, D.K., FrÝda, J., MänNIK, P. \& Loveridge, R.F. 2019. Integrated graptolite-conodont biostratigraphy and organic carbon chemostratigraphy of the Llandovery of Kallholn quarry, Dalarna, Sweden. Palaeogeography, Palaeoclimatology, Palaeoecology 508(1), 1-16.

DOI 10.1016/j.palaeo.2018.08.003

Walcott, C.D. 1911. Middle Cambrian annelids. Smithsonian Miscellaneous Collections 57(2), 109-144.

Walcott, C.D. 1919. Cambrian geology and paleontology IV. Middle Cambrian algae. Smithsonian Miscellaneous Collections 67(5), 217-260. 
Walcott, C.D. 1920. Cambrian geology and paleontology IV. No. 6. Middle Cambrian Spongiae. Smithsonian Miscellaneous Collections 67(6), 261-365.

Weigelt, J. 1927. Über Biostratonomie. Der Geologe 42, 1069-1076.

WestergÅRD, A.H. 1909. Studier öfver Dictyograptus-skiffern och dess Gränslager. Meddelande från Lunds Geologiska Fältklubb B4, 1-98.

Williams, S.H. 1979. An excursion guide to Dob's Lin. Proceedings of the Geological Society of Glasgow, Sessions 121-122, 1979-1980, 13-18.

Williams, S.H. 1981. Form and mode of life of Dicellograptus (Graptolithina). Geological Magazine 118(4), 401-408. DOI 10.1017/S0016756800032271

Williams, S.H. 1982. Upper Ordovician graptolites from the top Lower Hartfell Shale Formation (D. clingani and P. linearis zones) near Moffat, southern Scotland. Transactions of the Royal Society of Edinburgh: Earth Sciences 72, 229-255. DOI 10.1017/S026359330001004X

Williams, S.H. \& Stevens, R.K. 1988. Early Ordovician (Arenig) graptolites from the Cow Head Group, western Newfoundland. Palaeontographica Canadiana 5, 1-167.

Williams, S.H., Ingham, J.K., McManus, K. \& Murray, I. 1982. The use of experimental palaeontology in reproducing the effects of diagenetic flattening on graptolites. Lethaia 15, 365-372. DOI 10.1111/j.1502-3931.1982.tb01701.x

Wilson, L.A. \& Butterfield, N.J. 2014. Sediment effects on the preservation of Burgess Shale-type compression fossils. Palaios 29, 145-153. DOI 10.2110/palo.2013.075

Wilson, P., Parry, L.A., Vinther, J. \& Edgecombe, G.D. 2016. Unveiling biases in soft-tissue phosphatization: extensive preservation of musculature in the Cretaceous (Cenomanian) polychaete Rollinschaeta myoplena (Annelida: Amphinomidae). Palaeontology 59(3), 463-479.

DOI 10.1111/pala.12237

Wright, T.O. \& Platt, L.B. 1982. Pressure dissolution and cleavage in the Martinsburg shale. American Journal of Sciences 282, 122-135. DOI 10.2475/ajs.282.2.122

Yang, B., Steiner, M., Schiffbauer, J.D., Selly, T., Wu, X.,
Zhang, C. \& LiU, P. 2020. Ultrastructure of Ediacaran cloudinids suggests diverse taphonomic histories and affinities with non-biomineralized annelids. Scientific Reports 10, art. 535. DOI 10.1038/s41598-019-56317-x

Young, G.A., Rudkin, D.M., Dobrzanski, E.P., Robson, S.P., Cuggy, M.B., Demski, M.W. \& Thompson, D.P. 2012. Great Canadian Lagerstätten 3. Late Ordovician Konservat Lagerstätten in Manitoba. Geoscience Canada 39, 201-213.

Yu, J.H., Liu, H.B. \& FAnG, Y.T. 1985. Dendroids from the Xinchangian stage (early Ordovician) of the Xiushui Drainage Basin, Jiangxi Province. Acta Palaeontologica Sinica 24(1), $18-24$.

Zalasiewicz, J.A., Page, A., Rickards, R.B., Williams, M., Wilby, P.R., Howe, M.P.A. \& Snelling, A.M. 2013. Polymorphic organization in a planktonic graptoloid (Hemichordata: Pterobranchia) colony of Late Ordovician age. Geological Magazine 150(1), 143-152.

DOI 10.1017/S0016756812000349

Zhang, W.-T. \& Hou, X.-G. 1985. Preliminary notes on the occurrence of the unusual trilobite Naraoia in Asia. Acta Palaeontologica Sinica 24(6), 591-595.

Zhang, X., Wei, L. \& Zhao, Y.-L. 2008. Cambrian Burgess Shale-type Lagerstätten in South China: Distribution and significance. Gondwana Research 14, 255-262.

DOI 10.1016/j.gr.2007.06.008

Zhang, Y. \& ERDTMANN, B.-D. 2004a. Tremadocian (Ordovician) biostratigraphy and graptolites at Dayangcha (Baishan, Jilin, NE China). Paläontologische Zeitschrift 78(2), 323-354. DOI 10.1007/BF03009229

Zhang, Y. \& Erdtmann, B.-D. 2004b. Astogenetic aspects of the dendroid graptolite Airograptus (Late Cambrian-Early Ordovician) and their phylogenetic implications. Lethaia 37, 457-465. DOI 10.1080/00241160410002199

Zhao, Y.L., Zhu, M.Y., Babcock, L.E., Yuan, J.L., Parsley, R.L., Peng, J., Yang, X.L. \& Wang, Y. 2005. Kaili Biota: a taphonomic window on diversification of metazoans from the basal Middle Cambrian: Guizhou, China. Acta Geologica Sinica 79(6), 751-765.

DOI 10.1111/j.1755-6724.2005.tb00928.x 